

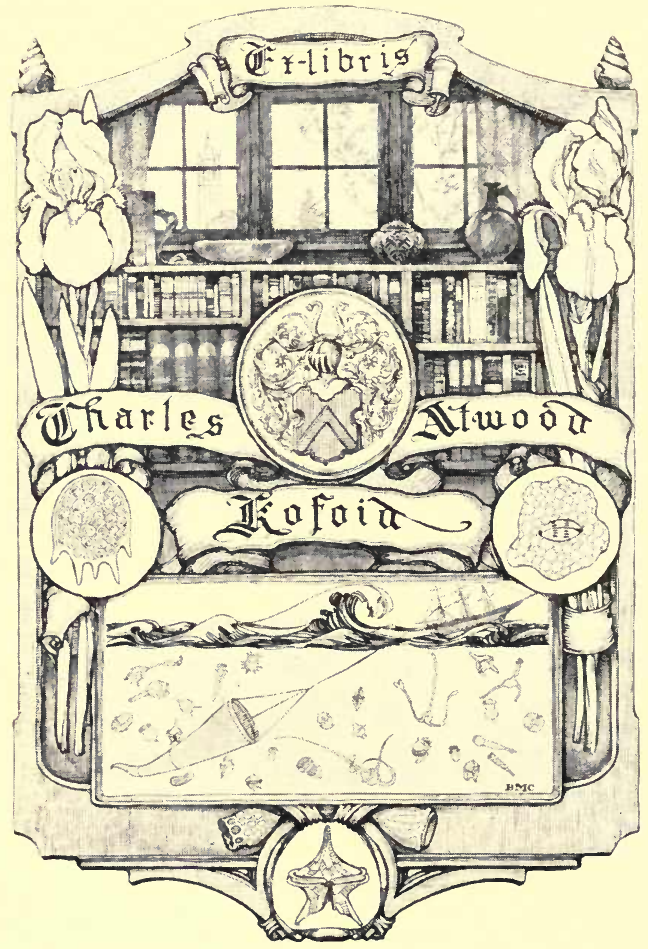




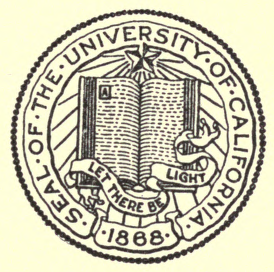

THE LIBRARY OF

\section{THE UNIVERSITY OF CALIFORNIA}

PRESENTED BY

PROF. CHARLES A. KOFOID AND MRS. PRUDENCE W. KOFOID 



\section{IN MY VICARAGE GARDEN AND ELSEWHERE}




\section{BY THE SAME AUTHOR}

IN A GLOUCESTERSHIRE GARDEN

PLANT-LORE OF SHAKESPEARE 



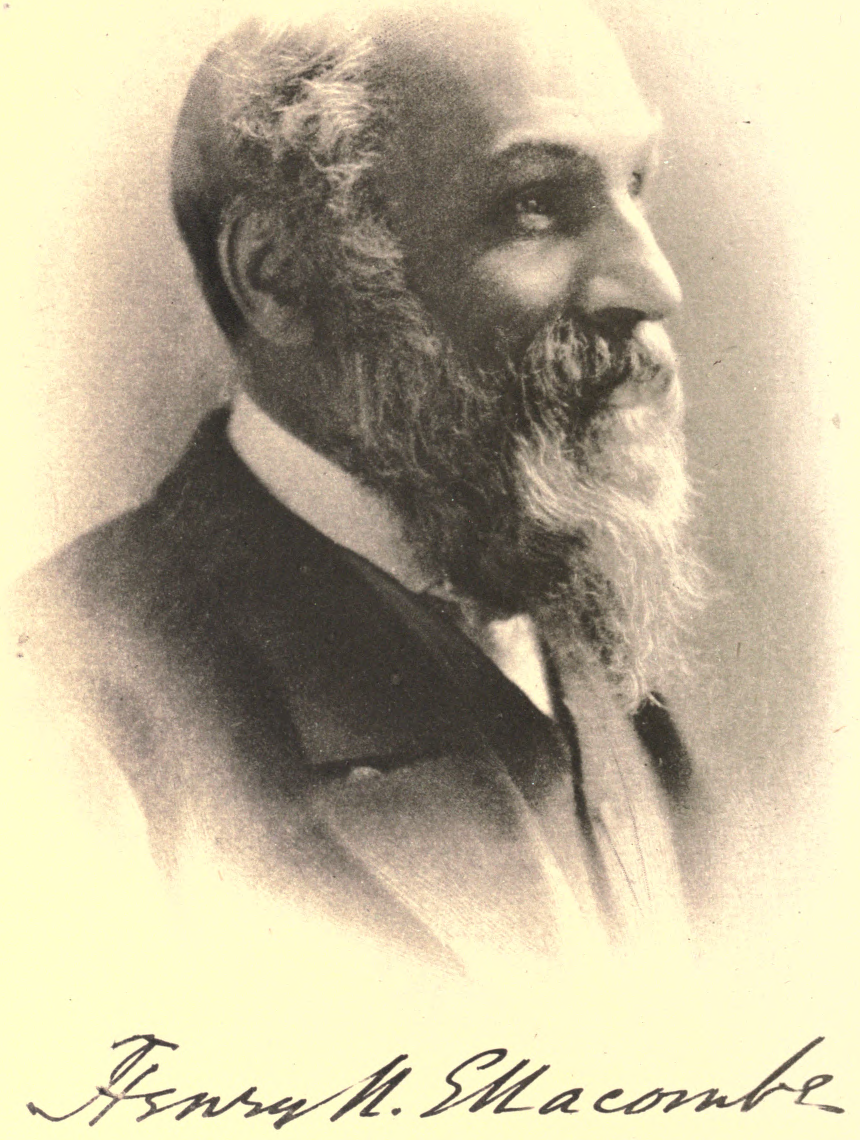




\section{IN MY VICARAGE}

\section{GARDEN AND}

\section{ELSEWHERE}

BY

Rev. HENRY N. ELLACOMBE, M.A. VICAR OF BITTON, GLOUCESTERSHIRE

“ I MADE ME GARDENS AND ORCHARDS, AND I PLANTED TREES IN THEM OF ALL KINDS OF FRUITS." - ECCLESIASTES.

JOHN LANE: THE BODLEY HEAD LONDON \& NEW YORK MDCCCCII 
Printed by Turnbull \& Spears, Edinburgh 


\section{P R E F A C E}

THIS little volume may be considered a sequel to my former book, "In a Gloucestershire Garden." All the chapters in it have already appeared as occasional papers in the Guardian, Pilot, and Gardener's Magazine, and I have to thank the proprietors of those papers for their courteous permission to publish the papers in book-form.

\section{HENRY N. ELLACOMBE.}

Bitton Vicarage,

November I901. 
y 


\section{Contents}

CHAP.

PAGE

PART I.-IN My Vicarage GaRden

I. The Flowers of Early Spring . . I

II. Flowers of Late Spring . . . IO

III. Flowers OF Summer $\quad$. $\quad$. 19

IV. Flowers of Autumn $\quad$. $\quad$. 28

V. The Mixed Garden . . . 38

VI. A Backward SPRING . . . 46

PART II.-ELSEWHERE-VARIOUS

VII. Sunshine and Shade in the Garden • 59

ViII. Carpet Plants . . . . . . 66

IX. The Garden under Snow . 72

X. THE ROCK GaRden . . . . $8 \mathrm{I}$

XI. YORK AND LANCASTER ROSES • • $9 \mathrm{I}$

XII. Plant Names $\quad . \quad$. $\quad . \quad$. 98

XIII. The Scents OF Flowers . . . 108

XiV. Medical Properties of Flowers . 120

XV. Railway Gardens • . . . $\quad$. 133

YVI. OUR National Gardens • • • 145

$$
\text { vii }
$$




\section{Contents}

CHAP.

XVII. Flora of England I800 Years Ago • I6o

PART III.-ELSEWHERE-SWITZERLAND AND SHAKESPEARE

XVIII. IN Wild Swiss GardenS • • $\quad$ - 177

XIX. PIORA

XX. Shakespeare AND Architecture • 206 


\section{PART I \\ IN MY VICARAGE GARDEN}

\section{CHAPTER I}

THE FLOWERS OF EARLY SPRING

WHEN does spring commence? And at what exact time of year may we look for our spring flowers?. By most people the answer would be readily given that spring commences with April, or it may be a few weeks earlier in forward localities; and that spring flowers are those that may be looked for in March, April, and May. But the thoughtful gardener may give a different answer; and I am inclined to look for the right answer in Bacon's happy phrase when describing his ideal garden, in which he would have Ver perpetuum. To the real lover of plants, spring lasts from the first of January to the thirty-first of December, and spring flowers are to be found all through the year. To put it in another way, spring is the time at which flowers wake out of their sleep, and the awakening takes place, not according to months, or even to weather, but according to the needs and nature of each different 


\section{In My Vicarage Garden}

plant. And if we take this interpretation we may begin our spring for garden purposes with the New Year; and if we are to have Ver perpetuum that must be the commencement of our gardening year ; and whether the weather is mild or cold the gardener will see signs of the commencement of spring even in what we usually call the depth of winter. I have but a poor opinion of a gardener who is only a summer or fine-weather gardener; and I do not call him a true lover of plants who can only see beauty in fully developed flowers; and that must be a poor garden which cannot show a plant-lover much to interest him in the shortest days; and the gardener, whether master or servant, must be a poor observer if he cannot see growth and progress in what is too often called the dead time of the garden. The garden is never dead; growth is always going on, and growth that can be seen, and seen with delight. Take this year's January (1900). During December there were several days of very great cold, which checked growth, and cut down many things that had survived up to that time. Yet, on the New Year, the garden was full of interest, and even beauty, for any one who knew how to look for it. True, there were very few open flowers, but there were some which were very precious. There were early crocuses, such as C. Imperati and stellaris, and Christmas roses, but, as I said before, the interest of a garden is not limited to flowers. It is really astonishing how little the 


\section{The Flowers of Early Spring}

majority of people seem to appreciate the value and beauty of green foliage, especially in winter. In some gardens it is the custom to fill the empty beds, which were in summer given to bedding plants, with small evergreen shrubs. The effect is seldom satisfactory; the poor little things cannot throw off the miserable appearance which marks them as the damnosa hereditas of summer bedding, and they can give no pleasure to any true lover of plants. But there are many perennial plants which will clothe the surface of the ground as well in winter as in summer, and can be allowed to occupy the ground the whole year without injuring any plants that the gardener may wish to use for the summer decoration of his garden. The hardy cyclamens are most useful in this way. The Neapolitan cyclamen flowers in late autumn, and is at once furnished with most beautiful large mottled leaves, which lie flat on the ground, and remain in full beauty till April or May. The C. Coum forms its leaves a little later, and before the flowers, but it, too, forms a beautiful carpet of close-lying foliage, and, where the soil is favourable, they will increase rapidly, and may be let alone for years. I have some large patches which I know to have been over eighty years in the same place, and they seem to me to increase in beauty every year, and there are few plants which multiply themselves so readily by seed. The stalk, immediately after flowering, twists itself and bends towards the ground, in which the 


\section{In My Vicarage Garden}

seed-vessel, still unripe, buries itself, and the seed germinates so rapidly that I have often found young bulbils fully formed and fit to handle and remove within six weeks of their flowering, the bulbils being snugly covered with one or two inches of soil. Ants and worms are said to be active agents in carrying the seeds of some cyclamens, but I do not know if they do so with these two species. Another plant which will cover the ground closely, especially in dense shade, is the Asarum Europeum, and it will even produce its curious, though inconspicuous, flowers in the depth of winter. There are many other good carpet plants which show their beauty almost more in winter than in summer; but to speak of all carpet plants would require a separate article, and I want to speak of flowers.

I suppose, if anyone was asked to name the special flowers of January he would name the Christmas rose, the crocus, the snowdrop, and the winter aconite. They are all undisputed beauties, and much could be said of each; but I must dismiss the Christmas rose and the aconite with only one remark, that, different as they are, they are very closely allied, and, almost alone among flowers, their many petals are like little twisted spills, and soon fall off; and in both the beauty of the flower is in the sepals, and not in the petals ; and in both the flower is formed beneath the surface of the soil, and the stem forces itself through in the shape of an arch, bringing the full-formed 


\section{The Flowers of Early Spring}

flowerbud after it. But of the crocus and snowdrop I must say more; and when one begins to speak of the crocus and snowdrop, it is hard to know when to stop. The snowdrop grows in many parts of Europe, and certainly grows in Italy, Sicily, and Greece; yet, in spite of its beauty and its being so conspicuous by the time of its flowering, there are no notices of it in Virgil, Theocritus, or Theophrastus. It may be the, $\lambda$ suróiov of Theophrastus and of the Anthologia Græca, but this is uncertain. It is not to be wondered at that it is unnoticed by all our earlier poets, for it is certainly not a native, and was not even known as a garden plant till well into the seventeenth century. This is quite certain from its being unnamed by Bacon in his account of the flowers for the early months of the year; it is not mentioned by Gerard in 1577 , but it is by his editor, Johnson, in 1636 ; Parkinson did not have it in I629, but he had in 1656 . It is the same with the foreign gardeners-Clusius knew it; but it is not in Laurembergius' excellent little book, "De Plantis Bulbosis" (I63I); nor does it find a place in that most delightful of all old books on gardening, the "Hortus Floridus" of Crispin de Pas, published in I6I4. It is very much the same with the pretty name. Whoever invented the name of snowdrop-i.e. earrings of snowdeserved a lasting record; but no one can trace him. Johnson, in 1636 , says that "some call them also snowdrops" - and so the name was 


\section{In My Vicarage Garden}

creeping in ; but it does not seem to have become popular soon, probably because the plant had not become common; but Boyle uses the name in $166_{3}$; and Evelyn in $166_{4}$, in the "Kalendarium Hortense," names among the "flowers in prime" in December, "snow-flowers or drops." And in connection with what I said above of Bacon's Ver perpetuum, it is interesting to note that under this month Evelyn says that so "it is that a Royal Garden or Plantation may be contrived according to my Lord Verulam's design" ; and, I may add, that he begins his account of the gardener's work by saying that "the gardener's work is never at an end; it begins with the year and continues to the next." The snowdrop is now one of our commonest garden plants, and the name is universal, and perhaps no plant is so popular with all from childhood to old age; though it is not granted to all to see in the mixture of colours, pure white, green, and a clear gold below all, purity with an undercurrent of passion, as Forbes Watson and Christina Rossetti were able to see in them. But then we are not all able, as they were, to see moral qualities of the highest or the lowest order in our flowers, or to read our own thoughts into them.

I must not trust myself with the crocuses-the subject is too large. The names alone, crocus and saffron, are a study, and fill many pages of appendix in that masterly account of the family, "The Genus Crocus," by G. Maw, the best plant 


\section{The Flowers of Early Spring}

monograph in the English language. But it is with the crocus as with the snowdrop. The headquarters of the family are in Greece and in Eastern Europe and Asia Minor, yet very little notice of it is taken by Greek or Roman writers ; and the early English writers have little to say of it, except for the medical and culinary virtues of saffron. But I know of few flowers that will better repay close attention than the crocus. There are many distinct species, and for any one wishing for a simple introduction to botany, the crocus is a very good plant to study, especially because the parts of the plants are so easily examined, and though to most people all crocuses are alike except in colour, the botanical differences between the species are well-marked and interesting.

Besides these humble plants there are many good shrubs in flower in January. The beautiful evergreen Clematis cirrhosa may be classed as a shrub, and in a mild January is often covered with its delicate spotted flowers; but it is a southern plant, and the flowers cannot stand much frost. There is the curious Garrya elliptica from North America, which, when covered with its long catkins, looking like a lot of small handbells strung together one over the other, is quite an ornamental shrub, and is so unlike any other plant that for many years it was put into a separate family all by itself. There are the two wonderfully-scented shrubs, the Chimonanthus 


\section{In My Vicarage Garden}

fragrans and Lonicera fragrantissima, with which may be joined on account of its scent the weedy, sweet-scented coltsfoot, with the scent of the heliotrope; while for beauty of flower few shrubs at any time of year can surpass the gorse and the Laurustinus. The winter-flowering gorse is the dwarf species $U$. nanus, very abundant in many parts, but local, and in flower sometimes very abundantly all through the winter from October to March. The Laurustinus, in spite of its name, is no laurel, but is a very near relation of our Guelder rose. It is the special ornament of the Spanish and Portuguese hillsides, and with us must be reckoned among the very best of the flowering shrubs where it will grow well, but it seldom does well in soil charged with lime; it will live there, but both in growth and flower is very inferior to those grown on the sandstone formations.

An American writer justly reckons among the pleasures of the winter garden that it is so instructive. In spring, summer and autumn the garden may be said to take care of itself, but "the winter garden," he says, "is never finished. One gains every season some new plant to be put on trial, and is pleased if every year it shows some slight gain." And what I have said is enough to show that even in December and January the garden is not, or need not be, all barren. Yet the gardener is always glad when December and January are past. He seems to 


\section{The Flowers of Early Spring}

have got through the worst part of the winter, and February is altogether a delightful month in the garden. Of course, he may have frosts, even destructive frosts; but frosts are not altogether bad either for the garden or the gardener. I am quite sure that for English gardens what Coleridge calls "the secret ministry of frost," is a ministry that cannot be spared; and for the gardener it is a ministry that teaches patience and watchful carefulness. "Gaudet patientia duris," says Lucretius; and he is but a foolish gardener who is always expecting losses instead of hoping for successes. The losses may come, to some extent they certainly will come, but the advice of the elder brother in "Comus" is the truer wisdom-

"Brother, be not over exquisite

To cast the fashion of uncertain evils ;

For grant they be so, while they rest unknown, What need a man forestall his date of grief, And run to meet what he would most avoid?

Or if they be but false alarms of fear, How bitter is such self-delusion !" 


\section{CHAPTER II}

\section{FLOWERS OF LATE SPRING}

THE first four months of this year were to the gardener four months of anxiety, and, to some extent, of disappointment. After the long, dry, hot summer, followed by abundance of rain in the late autumn, there was good reason to expect an early, perhaps an abnormally early, outburst of spring flowers, and so there doubtless would have been but for the frosts in December. They were not very severe, and did not last long, but they were sufficiently severe to alter all the prospects of an early spring. It was really quite surprising how great a change was brought about by even those few days of severe frosts. Instead of an early outburst of flowers we had an unusually late one, and the proofs of this were seen in every part of the garden. In I 898-9 I was able to pick an abundance of flowers of the sweet Chimonanthus fragrans to send away for the Christmas and New Year, and I know of few more acceptable Christmas presents to friends who have no gardens than a few of these deliciously scented little flowers. There is no special beauty in the pale yellow flowers striped with purple, but when placed in a saucer with a little water a few will perfume a room for weeks. 


\section{Flowers of Late Spring}

It is a shrub that should be in every garden, but it requires a wall. It is one of the most difficult of shrubs to propagate by cuttings or layers; but it sometimes produces its curious seed vessels, looking like brown broad beans, and the seeds come up readily. This year, instead of being able to send them away in December and January, I could find none fit for picking before February. It was the same with the beautiful Iris Stylosa, from which in I898-9 I could pick good flowers at Christmas and the New Year; but this year I could pick none before February, when they were most abundant. I wonder this most beautiful plant is not grown everywhere. It is not a rare plant, and can be got in quantity at a very cheap rate; yet I seldom see it except in gardens that have a fairly large collection of plants. There are many varieties, all beautiful; but one, to my mind, stands above all, a very rich deep blue with broad petals; I believe it has some special name which I do not know.

Altogether it was a late season; and it showed itself to be so in many ways. In 1899 Easter was a week earlier than this year, yet for the Easter decorations of 1899 it was very difficult to get daffodils in any quantity; in some, parts they were quite over. This year it seemed at one time very doubtful whether they could be had at all; they did not "take the winds of March with beauty," and just before Easter the milder weather and bright sun brought them all out at once, but 


\section{In My Vicarage Garden}

they did not last very long. It was natural to suppose that this short life of the flowers was owing to the powerful sunshine that we had at that time; but I cannot help thinking that, though the flowers did not open, the work which the flower has to do was not altogether delayed, and that the formation of seed was to some extent going on, so that when the flowers fully expanded their work was half done, and there was nothing left to be done by them but the finishing the work and then passing away. It is known that this is the case with the high Alpines; their work of perfecting their seeds must be finished before a given time: and if owing to a late melting of the snow the flowers are late, yet the seeds are not proportionally late, and are perfected in good time. I do not say that this is the case with all high Alpines, but it certainly is with some; and I have little doubt that it is so with many other plants and was so with the narcissi this year. There is no need to recommend daffodils to English gardeners; they are everybody's flowers, and have been so for generations; but I suppose they were never grown to the extent they are now. And for those who like to study their history there is much interest. It is very doubtful whether our daffodils are the narcissus of Homer and Theocritus ; they may be, and it is pleasant to think that they are; and if they knew the plant at all it is probable that they knew the Tazetta daffodils. Theophrastus describes a narcissus, but as it had green flowers 


\section{Flowers of Late Spring}

and flowered in September, it cannot be any of our daffodils. If the flower was as abundant in the South of Europe in former times as it is now, it is very surprising that so little notice is taken of it by Latin writers. Virgil names it, but as he describes it as sera comantem, it must be very doubtful whether it can be our favourite flower; but Pliny's description of it as "a white flower with a purple cup or bell within" seems to point to the poet's narcissus; and it is worth noting that he discarded the fable of the connection of the flower with the boy Narcissus, for "it took the name in Greek Narcessus, of Narce, which betokeneth numbednesse or dumbnesse of sense and not of the young boy Narcissus as the poets doe faine and fable." But I must leave the narcissus, for there is no limit to its interest, and it needs no words of mine to spread its praises.

The tulips behaved this year very like the narcissus. They delayed their time of blooming till the weather was genial, and then they all burst into beauty at once. I suppose more has been written about the tulip than about any other bulbous plant, and of late years the number of known species has been largely increased from Eastern and Central Asia and Asia Minor. Though we have a very beautiful native tulip, the cultivation of the tulip as a garden flower does not seem to have commenced much before the latter part of the seventeenth century. Bacon mentions an 


\section{In My Vicarage Garden}

early tulip flowering in January and February, and I do not know what he meant by it; the others he places in April. Evelyn also mentions "precoce tulips" as in flower in January. I need not say anything of the rapid rise of the flower into popular favour till it culminated in the tulip mania; but though the flower has never entirely gone out of fashion, it has had more ups and downs than most flowers. Van Oosten, a Dutch gardener, who published an excellent English book on gardening in 1703 , after giving his opinion that the art of gardening could go no further than the tulips which he produced, refused to tell the secret of his cultivation, because "it is a madness to give laurels to an ass who deserveth only nettles"; and he says that, "having been the most beloved object of princes, they are at last become the subject of the scorn of men." There is complete evidence that the name was given by Gesren from the Turkish Cap, and the name, with slight changes, has been adopted in most of the countries of Europe.

I am not now giving a complete list of the many beautiful flowers that brighten our English springtide; I am only picking a few here and there, and among the chief ornaments of spring I reckon the flowering shrubs. This year the shrubs have been clothed with a beauty that few of us have ever seen before. The laurustinuses were sheets of white, but they did not like the cold winds of March and April. The different 


\section{Flowers of Late Spring}

forms of the Pyrus japonica were covered with flowers and defied the winds, and so lasted in flower a long time; Photinia serrulata has a special beauty of its own in its young shoots, which at a very short distance look like fine flowers; but this year my tree had flowers for the first time, though the tree must be quite fifty years old; the flowers are pretty, but not striking. The Forsythias were all beautiful, but with us the $F$. suspensa grown against the house was far the best, and was like a golden curtain at least fifteen feet high. After flowering the whole plant is cut in close, and at once begins to form the new shoots that will bear flowers next year. All the magnolias have been loaded with flowers, and surely no other hardy flowering tree can bear comparison with these early flowering magnolias, except perhaps the horse chestnut. And, to name no more, the pretty Azara microphylla, with its dainty foliage, had the backs of the leaves covered with its little flowers; the flowers are of small beauty, but they have a strong Vanilla-like scent which can be felt many yards away.

I think the spring of 1900 will be memorable in many ways in the garden. I cannot remember a season in which flowers were so abundant on almost every flower-bearing plant-not, however, on all, for the crown imperials in my own garden and in most of the gardens in the neighbourhood were stunted in growth and had very few flowers. Why this grand old plant should this year be 


\section{In My Vicarage Garden}

an exception to almost every other plant, whether tree, bulb, or herbaceous, is a puzzle which I cannot solve. The fruit trees were all as full of flower as they can well carry, and there is a promise of an abundance of fruit of all sorts. The plum-trees were a wonderful sight, as they all burst into flower at once, soon after Easter; and where the orchard was surrounded by a hedge of their near relation or ancestor, the blackthorn, the beauty was much increased. The blackthorn brought with it the usual "blackthorn winter," but it was short and not severe enough to do harm. The season also introduced me to a beauty in tree life which was quite new to me. We have very few wild birches in Gloucestershire ; but I was in Surrey just after Easter, and was surprised to see the birches apparently surrounded with a pale golden mist that I had never noticed before. The apparent mist was produced by the catkins which generally come out with, or even after the leaves; this year they came out first, and so their beauty was not hidden. Another very marked feature in the garden this year is in the seeds. All sown seeds have done wonderfully, whether sown in pots and raised by heat, or sown in the open ground. This naturally comes from the dry sunny summer of 1899 , which fully ripened all seeds. And it was most apparent in the number of self-sown seedlings that have shown themselves, in many cases for the first time. I never before had the pleasure of seeing self-sown seedlings of 


\section{Flowers of Late Spring}

the grand Eryngium Alpinum coming up by the side of the parent plant; nor have I ever before been troubled with seedlings of the globe thistle; this year I have had to hoe down a large patch of them; and I have not till last year known the Japanese Kohlreuteria even ripen its seeds, but it did so last autumn, and dropped them on the ground, on which they lay exposed all the winter, and there are now scores of young plants showing themselves. And so these different points of interest in this spring, the abundance of flowers, the extreme strength and vigour of almost all vegetable growth, and the full ripening and ready germination of seeds show that the beauty of any season does not depend on the weather of the moment; the beauty has been laid up and been matured for us by the weather of many previous months - it may be of many previous years.

I cannot close without a short record of the wild flowers of this spring; they were really wonderful. I have mentioned the blackthorn, which in some parts divided the fields with lines of silver, but in the fields there was such a glory of dandelions, buttercups, and celandine, that one felt ashamed to call them weeds. Primroses and cowslips were unusually abundant and fine, and so were the wood anemones and bluebells, and I never remember such an abundance of the flowers of the wild oxalis, which I think one of the most graceful of our wild plants; but the flowers are very often much hidden by the leaves. If it were 


\section{In My Vicarage Garden}

not a British weed, we should certainly grow it on our rockwork as a special beauty; it soon becomes troublesome there, but I admit the rosecoloured form as quite a little gem. Not only in England, but also in Spain and Portugal this little wood flower is called Alleluia, and it is no strained interpretation that the name was given from a strong religious feeling that the humblest herb or flower declares the glory of God and showeth His handiwork, as well as the heavens and the firmament. If we can learn this lesson from our spring flowers our love and admiration for them will not be wasted. 


\section{CHAPTER III}

FLOWERS OF SUMMER

THE season of summer, meaning especially the months of June, July and August, is to every gardener the most enjoyable of the four seasons. It is the season to which he has been looking forward in all the different processes of cultivation; it is the season of enjoyment ; the season in which, with a few occasional drawbacks from bad seasons, or it may be from wrong cultivation, anxious preparation ends in success; the season of hopes now ended in the reality of sight, when we need no longer hope for that we see not, and with patience wait for it, but may feast our eyes on the beauties which we have waited for, and to some extent have created, and in which we cheer ourselves with the delightful feeling that our labours have not been in vain, and so we will go on the next year as cheerfully and as hopefully as ever. For I hold it as a firm article of faith in gardening that there has never been in any year what can be called complete failure; there are, of course, failures and disappointments in some parts of the garden, but there have been unlookedfor successes in some other parts, and on the whole the compensation has been great enough to 


\section{In My Vicarage Garden}

stop all grumbling. But in this particular year (I900) there has been little or no cause for grumbling, because the failures have been so few, while the successes have been so many. I suppose the oldest among us cannot recollect a year in which there has been such a marvellous abundance of flowers, such healthy growth, and such richness of colour in the flowers, and such a delightful season in which to enjoy it all. It has been so all the year. I noted it in what I said of the flowers of spring, and the flowers of summer have carried on the story. The fruit trees were beautiful pictures, with scarcely an exception-beginning with the plums, the pears, apples, cherries, and all the wall fruits were so laden with flowers that if the fruit had been in proportion to the flowers the crops would have been almost too much for the trees; but in this part of the country many of the flowers were abortive, and so the crops, though probably above the average, are less than many looked for.

Then came the roses, and they surpassed themselves. In my own garden I have never seen such a display of the beautiful rich yellow $R$. hemispharica, a rose of which I am very fond, not only for its beauty, but also for its long history and many associations ; for it is one of the oldest roses in cultivation. It is true that it very seldom shows its full beauty, for it forms its flowers very early and they are apt to be injured by late frosts, or even by cold nights some degrees above 


\section{Flowers of Summer}

freezing, and it never fully opens its flowers; but even in its hemispherical state it is very beautiful both in shape and colour; and on one of my bushes, grown against a wall, I must have had nearly two hundred blooms, more or less open at the same time-really a grand sight. It was very much the same with all the roses; they were very abundant, very full-coloured, and very clean, and the dry sunny July has produced an unusual effect among the single roses. They are laden with their handsome fruit (hips) at least a month or even six weeks before the usual time, so that we have this year the beauty of their fruit (which I consider a very great, and, in some species, perhaps even the chief beauty) for a month or six weeks longer than usual. But while the garden roses were so beautiful, I noted that among the wild roses the case was quite different. I cannot say why it should be so, but the absence of our beautiful wild roses in the hedgerows was very marked. I was in Tyrol, chiefly among the Dolomites, during July, and the roses were very few, and those few very deficient in flowers. Among the herbaceous plants, the effects of the fine weather of 1899 were seen everywhere. Larkspurs were very grand, and even such moistureloving plants as the phloxes were quite happy in spite of the drought. The fine summer and autumn of 1899 had given them such vigour that they were able to hold their own in the drought of June and July, and both in size and colour 


\section{In My Vicarage Garden}

they were excellent. It would be too long to go through many more of the herbaceous plants; it is enough to say that, with scarcely an exception, they were all so vigorous that the record of their beauty in the summer of 1900 will be a lasting memory to every gardener.

I must go to the shrubs, for it was in the shrubs especially that the long heat of the summer of I 899 produced such wonderful effects in the summer of 1900 . Wistarias, both white and blue, almost recalled the pictures that we have seen of them as grown in the gardens of Japan, where they are especial favourites; but I was surprised that none of them produced fruit. I have never seen the fruit of the blue Wistaria, but last year my white one had a great many of its pretty bean-like fruits; this year there were none, though the flowers were abundant, and looked so healthy that in such a summer I naturally looked for a crop of fruit. The Catalpas were everywhere loaded with flowers, but in my own garden the beauty both of leaves and flowers was much marred by the strong gales in the beginning of August. The Christ's thorn (Paliurus) was a sheet of pale gold, and was, I think, more beautiful in my own garden than where I saw it in its wild habitats in North Italy; it is a plant that I admire for its beauty as much as for its historical interest, and I wonder it is not more frequently to be seen in English gardens. But if I were to pick out the shrub 


\section{Flowers of Summer}

that has more especially distinguished itself this summer, I should pick out the Rhus cotinus. It is one of the Sumach trees, and is known as the Venice or Varnish Sumach, and is found in many parts of Southern Europe, and may be seen in great abundance on some of the hills round the Italian lakes. Pliny says it is found on the Apennines, and is used for wood inlaying; and it is from him that we have got the two Latin names, while Sumach is from the Arabic. The great beauty of the tree is in its flowering, if, indeed, that can be called flowering where there are no true flowers. The whole shrub is covered with large panicles of abortive flowering stems, in which the true flowers are entirely absent, and nothing remains but the stems. Yet those bundles of flower stems form the most beautiful vegetable feathers, resembling marabout feathers. It is from this wig-like appearance of the tree that it has its French name of Arbre de perruque, and its English name of Smoke Tree. There are two varieties: in the wild form, and in the form usually seen in gardens, the panicles are a dull whitish green, but the far more beautiful form has the panicles a rich rose colour, and this variety is, I think, the most beautiful of shrubs, and as it keeps its beauty for several weeks it is a shrub that all ought to grow. Whoever does grow the shrub should make a point of carefully studying its structure; and he or she will find much interest in it, and will thank me for drawing 


\section{In My Vicarage Garden}

attention to it. For it is absolutely unique in the plant world, with the exception of its near relation the North American $R$. cotinoides, a plant which I strongly recommend for the beauty of its foliage in spring and autumn, but I have not seen the flower. The peculiarity of the structure is that the flower stalks which form the panicle are perfectly smooth when first formed, and remain smooth if they bear flowers; but if, as is usually the case, they bear no flowers, the stems are covered with rigid hairs which add to and even form the wigginess of the shrub; and though botanists have tried to explain the connection between these two peculiar characters of the tree, they remain unexplained and are absolutely unique. There are, we know, many plants which by cultivation have had their flowers converted into what we should call more useful parts; and there are some which man uses before the flowers are formed, such as the caper, the clove, the cauliflower, the pineapple, and others, but all these have been purposely changed by man ; in the wig or smoke tree the work is all nature's.

Coming to bulbs, and speaking of them very shortly, it has certainly been a good year for lilies. My own garden is not very favourable to lilies, but I had some very good ones this year, especially some of the North American lilies, also the martagons, and the fine South European L. pomponium; and the Madonna lily, which is at once the most beautiful and the most capricious of all, has this year, 


\section{Flowers of Summer}

wherever I saw it, been very beautiful and free from disease. For this again, no doubt, we have to thank the long hot summer of I 899, which thoroughly roasted the bulbs, and so made them strong and able to fight against their many enemies.

Another tribe that has been in great vigour this summer is the grass tribe, the Graminea. The Arundo donax, or false bamboo of Southern Europe, has reached a height this year beyond all former years, both in the green and in the variegated state, and it is the same with the bamboos. Like many other plants this year, they started very late; some of them gave no sign of new shoots till the rains of the latter part of July came. For this they waited patiently, and when it came their growth was wonderful. I have a good plant of the Phyllostachys Castillonis, which, with its alternatives of green and gold in the stems, I consider the best of all the hardy bamboos. It is considered a little tender, but it has lived with me many years. Last winter many of the stems died, and though I knew the plant was alive and healthy I was beginning to think that it might not send up new shoots this year ; but after the rain it started into full growth, and in less than one week it has sent up splendid shoots, some over ten feet in length, which will probably be fifteen feet or more before it stops growing.

The richness of the foliage of all plants, whether 


\section{In My Vicarage Garden}

herbaceous, or trees or shrubs, deserves a passing notice. In spite of the drought in June and July, the freshness of the foliage everywhere has been a thing to notice and rejoice in. But I do not want to dismiss the garden without saying something of the weeds, which form so large a feature in many gardens. If we have a fine season for the garden we must expect plenty of weeds; it is part of the price we pay for it ; for the weather that is good for our choice flowers and vegetables is as good for the weeds. I am one of those who think that weeds in a garden are, within a certain-limit, not altogether an unmixed evil; and certainly I would rather see a flower border with a mixture of flowering weeds than with a few plants and large continents of bare soil. But in a well-kept garden weeds have no place, and when the garden is not surrounded with fields there should be little difficulty in keeping them at bay, even with a small staff of gardeners; where it is surrounded by fields it becomes almost impossible. But it can be done, and I will finish my paper with one useful hint on the subject. I should class the plantain as the worst of all weeds, especially to a good lawn. There are many plans for destroying it, such as specially made spuds, instruments for inserting sulphuric acid or other poison into the plants, etc., and none of them succeed completely. But a complete remedy can be found in common table salt. Place a piece about the size of a hazel nut on the very middle of the plant in hot, dry 


\section{Flowers of Summer}

weather. Don't spread it, and don't make a hole in the plant, but leave the salt on it, and in two or three days the leaves will blacken, and the root will so completely perish that I have known a hole left in the grass of two or three inches diameter. This soon fills up, and the plant will not appear again. Experto crede. A very few years ago I had large carpets of plantain on my lawn; they are all gone, and in their place are carpets of rich turf. If any of my readers tries the experiment, I hope he may be as successful as I have been. 


\section{CHAPTER IV}

\section{FLOWERS OF AUTUMN}

THE general idea of autumn is that it is the season of decay, and the passing away of the beauty of the garden. I do not think so; I prefer to look on autumn as the season of full maturity, the time of year when the life of the plant reaches its full perfection. To the real student of plant life the sleep of winter, the resurrection of spring, the full-blown flowers of summer are only so many steps towards the final stage of the ripened fruit, which is the great point at which all plants gradually arrive, and which is really the true object of their existence ; and it is not till the final point has been reached and passed that real decay sets in. Looking at our garden with this mind the autumn is not a time of sadness; it may even be a time of rejoicing at the fulness of life which autumn shows, and more than that, a rejoicing in a fulness of beauty. ${ }^{1}$

For a fine autumn is a time of great beauty, and it is certainly not a time when our gardens are bare; there are still a vast number of beautiful flowers to be seen which will bear comparison

1 Pulchrorum Autumnus Pulcherrinus.-BACON, Of Beauty. 28 


\section{Flowers of Autumn}

with the flowers of midsummer. Putting aside such flowers as dahlias, China asters, chrysanthemums, and other tender plants which yet add much to the gaiety of the garden in autumn, there are good hardy herbaceous plants and shrubs which give brightness to the garden till the frost comes. Chief among these are the different species of perennial sunflowers (helianthus) and the asters or Michaelmas daisies. Asters are found in almost all cold and temperate countries; one species, the Marsh Aster (A. tripolium) being found in England all round the coast, but delighting chiefly in the saltmarshes of the estuaries : the flower is a poor one, and the plants scarcely deserve being brought into the garden. But there are two in Europe which may be reckoned among the best of the family, the dwarf $A$. Alpinus, so well known to all travellers in Switzerland, and the $A$. amellus, a native of many parts of Southern Europe, including Switzerland. There seems no reason to doubt that this is the Amellus minutely described by Virgil :-

Aureus ipse ; sed in folüs quae plarima circum

Funduntur, violae sublucet purpura nigrae.

GEORG. IV. 27 I.

where the ipse is the central disk, and foliis the petals or ray. This aster is with me the earliest to flower, and the most beautiful, and more than any other flower it is a great attraction to butter- 


\section{In My Vicarage Garden}

flies and moths; this year it was crowded with Red Admirals and occasional Humming Bird moths. Most of the other Michaelmas daisies come from America, and the proper determination of the many different species has been a sore puzzle to all American botanists; but they were taken in hand by the late Asa Gray, who brought them into good order; yet even he, though so great a botanist, hesitated for some time to undertake to clear up the confusion, and when he did so he has left a record. "Never was there so rascally a genus; they reduce me to despair." The difficulty has arisen from the fact that they hybridise very easily, and there are, besides the garden hybrids, many natural ones. Of these garden hybrids many are very beautiful, but I really think that none are better, or even so good, as the types; and in most small gardens it would be well for the gardener to confine himself to a dozen or, perhaps, even half a dozen. These if grown well, i.e. well fed and looked after, would give all he would want. There are some which I should on no account leave out, such as $A$. amellus, $A$. ericoefolius, $A$. Nove Anglice (blue and red), $A$. longifolius ramosus, $A$. versicolor, $A$. turbinellus, and $A$. grandiflorus. This last one is a most desirable plant; in colour it is even a deeper blue than $A$. amellus, and it has the great advantage of flowering so late that in mild seasons it will give good flowers in December and even at Christmas; and the older gardeners recommend 


\section{Flowers of Autumn}

that it should not be allowed to flower out of doors, but that it should be picked in bud and brought indoors, when the flowers would gradually open and remain in full beauty for many weeks. But it is a little tender, for it is a native of the Southern United States, and in a severe winter it is apt to disappear. But among autumn herbaceous plants, I think none surpass the autumn crocuses. There are many species mostly from Eastern Europe, and all are beautiful; but all are not very easily grown, for they are capricious, and in many gardens the only ones that can be grown easily are $C$. speciosus and $C$. nudiflorus, and these are really the handsomest, and when they are once established they increase rapidly. In my garden the one that has made itself most at home is $C$. pulchellus, a lovely pale blue with white anthers-this sows itself, not only where it was planted, but in the turf near it.

Autumnal flowering shrubs are a great feature in the garden, but I can only mention a few. The autumn roses are in many cases, especially among the hybrid teas and Chinas, superior to those in summer; certainly they have been so this autumn, and where roses are grown in large quantities, I think it a good thing to sacrifice the summer blooms for the sake of the increased beauty in the autumn flowers. A very pretty autumn shrub is the Abelia Chinensis; it seldom flowers before the middle of September, but it lasts in flower six weeks or more; and the com- 


\section{In My Vicarage Garden}

bination of the reddish-brown stems, and the abundance of the small white flowers, each set in a pale-brown starry calyx, gives a combination of colour that is exceedingly pretty. Another halfshrubby good autumn flower is the Phygelius Capensis, and the arrangement of the flowers is worth noticing. Each flower-stem or petiole starts from the main stem at a right angle, and from this the flower hangs at a second right angle, so that the main stem, the petiole, and the flower form three sides of a square. The arrangement for the fertilization is very elaborate, but if it should fail, the flower as it falls is like a tube open at both ends, and in falling to the ground the bottom ring forces together pistil and stamens, and so produces fertilization. I also strongly recommend the despised fuchsias as among the best of autumn decorative shrubs. They are rather more popular now than they were some years ago, when it was considered an artistic heresy to admire them, but they are still seldom seen; yet they are quite hardy, though most of them die down in the winter, and in the autumn they give an abundance of flowers borne on bushes that are never unsightly.

The fruit-bearing trees and shrubs of autumn add largely to the beauty of a garden. I do not know why so few people grow the Japanese Persimmon (Diospyros Kaki), but I seldom see it in the open ground. Yet it is quite hardy, has very handsome foliage, and when the tree has a good 


\section{Flowers of Autumn}

crop of fruit it is a really striking object, for the fruit is as large as an orange, of a bright gold colour at first, gradually turning, as it ripens, to a rich crimson. The sea buckthorn-Hippophee rhamnoides-is another shrub very seldom seen, but always admired; the contrast between the pale grey foliage and the orange-coloured fruit is unusual and beautiful. It is a native of Great Britain, along the sea-coast, delighting in sand dunes; but it is a diœecious shrub, so that it is necessary to have a plant of each sex. And, taking the word "fruit" in its full botanical sense, i.e. the part that bears the seed, it would be wrong not to mention among autumnal fruittrees the common traveller's joy, that is now so beautiful in every hedgerow. Few wild plants have been so noticed as this, and every European country seems to have given it a separate name, proving its popularity. Gerard claims to have given it the name of traveller's joy; before his time the English name was hedge vine, or downy vine, for "the hedges in summer are in many places al whyte wyth the downe of thys vine" (Turner). It is this "down" which has given it so many names, as "old man's beard," "angel's tears," etc., and it is this down which gives to it its great autumnal beauty. The wild one is too rampant a plant to be admitted into gardens, but I can strongly recommend two species that should be in every garden. One is $C$. paniculata, a Japanese plant of recent introduction, a very 


\section{In My Vicarage Garden}

rapid climber, and producing an abundance of sweet-scented flowers in October, somewhat resembling the South European C. flammula, but with much handsomer foliage; the other is C. orientalis, or graveolens, with pale yellow flowers, or in the variety Tuganica, golden yellow, followed by very beautiful heads of seed, as large or larger than the Traveller's Joy, but much more silky. Before leaving the flowers of autumn I feel bound to say something about the autumnal gorse ( $U$. nanus), because in writing about it among early spring flowers I was taken to task for confusing between the common and dwarf gorse; my critics saying that the dwarf gorse is the flower of summer, and the common one of winter and spring. I cannot fully go into the question, but I may say very shortly, and I hope without rudeness, that I was right; I have lately seen the dwarf one in full flower, and so it will remain till after Christmas, in many places nestling under its taller relation.

I have left myself too small a space for the colours of autumn; it is a very large subject, and the more I study them the more I feel how little I know about them, and the more also I feel surprised that so little account of them is ever taken in scientific descriptions. To me it seems that the autumn colours of tree foliage are as absolutely a fixed mark of the tree as the colour of the flowers, and to some extent even more so. But scientific botany will not allow of it. Long 


\section{Flowers of Autumn}

ago Linnæus laid it down as a canon that colour could not be used as a differentia-it is too changeable; color in eadem specie mire ludit hinc in differentia nil valet; and we must agree that so it must be. Yet differences of colour are noted in flowers, and it is not easy to say why they should not be noted in leaves, but they are not. This year the autumn tints were very late, and in most cases very poor. In the Thames valley the beech showed no change of colour even in the second and third weeks in October, and in my own garden, the Parrotia Persica, often a marvel of many colours, showed none this year. On the other hand, the Salisburia was as beautiful as ever, but very late and for a very short time; and, as in former years, the Rhus cotinoides was by far the most beautiful of all autumnal shrubs. The thin leaves allow the light to shine through them, and when so seen I can only compare their colour to the richest old cathedral ruby glass; the mixture of deep crimson, with a suspicion of gold, is almost peculiar to this fine North American shrub. I must not dwell further on the autumn tints and colours except to say that every year I see something of fresh interest and beauty in them. This year I note two things that I had not noted before. In the Salisburia the rich colour begins at the lowest branch of the tree and works upwards; with most other trees the course is different; and in Cotoneaster horizontalis the deep red of the leaves begins 


\section{In My Vicarage Garden}

close to the central stem of the branch and works outwards, so that close to the stem the colour of the branch or branchlet is deep red on the inside and pure green on the outside. One other remark on the colours and I have finished with them. In America the autumn colours are of a brilliancy of which we know nothing here; I have not seen them, but all the accounts agree in giving the prevailing colour as red or scarlet. With us they are more or less yellow, probably really so for the most part, except in the beeches, but with the poets they are always yellow. Shakespeare talks of "the sear and yellow leaf" and of "beauteous spring to yellow autumn turned"; and he describes autumn as the time

When yellow leaves a few or more do hang

Upon those boughs which shake against the cold,

Bare ruined choirs, where late the sweet birds sang,

and other poets follow suit. But one essential feature of our country scenery is wanting in colour of any sort, and this I have never seen noticed in any author. Our hedges get no colour; they are simply brown lines skirting the fields, except in very old hedges, where the planted hawthorn has been covered, and sometimes even destroyed, by a natural growth of maple, hop, night-shade, and bryony. Then they show a rich picture of many colours.

I have said enough to show that to me autumn is not a dreary or cheerless season in the garden, 


\section{Flowers of Autumn}

and if we may learn a parable from the season I should say it is not, or need not be, a dreary season in human life. If a man will of set purpose lament over the approach of his autumn or its actual arrival, living only on past remembrances and fading memories, it is open to him to do so, but he must take the consequences on himself and blame himself more than the unavoidable time of life. To those who like to look on the bright side of things, I would recommend a very beautiful chapter, entitled, "l'Automne," in the "Connaisance de l'ame," of M. Gratry. It gives in a very striking way the advantages and disadvantages of the autumn of our lives, with a large balance in favour of the advantages. No, I cannot allow that the "calm decay" of autumn is altogether dreary; true it is that the flowers have passed away, and the swallows are gone: but flowers and swallows do not make up the whole of life, and "Time will bring on Summer," and the swallows will return. 


\section{CHAPTER V}

\section{THE MIXED GARDEN}

I Do not wish to enter into the vexed question whether "bedding-out" and "carpet-gardening" are worthy of the name of true gardening. The question is a very old one, and has often been debated with unnecessary warmth. For I hold that there is no such thing in gardening as fixed canons binding on all, but that a garden is, indeed, "the greatest refreshment to the spirits of man," and if one man is more refreshed by the stiffness of a bedded-out garden, and another by the greater freedom of a mixed garden, let each please himself in his own way: "let every man," as Parkinson said, "if he like of these plans, take what may please his mind, or out of these or his own conceit frame any other to his fancy, or cause other to be done as he liketh best." Yet I must say that bedded out gardens give me very little pleasure; the monotony of the same patterns and colours for four months of the year, and then (very often, though not always) bare earth for the remainder, is to me wearisome and oppressive. That there are advantages in the system I do not deny. Where a gardener or his employers have no real love of flowers, or little knowledge of 


\section{The Mixed Garden}

them, and only require that the ground should be "furnished" during the summer months, the bedding-out will exactly do for them what they want. The order is to supply "a blaze of flowers," and if a blaze of flowers is the test of good gardening then a bedded-out garden in the summer months shows the perfection of gardening. And in some places it seems almost necessary. As a foreground to large, stately houses the bedded-out parterre forms a fitting ornament; and it also seems in its right place in front of such buildings as the great palm-house at Kew, where all the immediate surroundings are stiff and artificial. Even where the circumstances are not such as these, I would leave it to each man's taste to arrange his garden as he thinks best. I am not bound to follow his example, but I certainly have no right to impute want of taste to an arrangement which does not please me. Within certain limits I can admire the stiffest bedded-out garden-the individual flowers at least have their charm, though the standing rule of bedding-out is that the individual is to be sunk in the mass ; but there is one limit to my admiration. In no way can I admire the so-called carpet or cushion beds, in which certain patterns are worked out as flat as possible. Such beds I can in no way call gardening. They represent the maximum of labour with the minimum of healthy results ; they are the degraded successors of the "knots" of our forefathers, and can only 


\section{In My Vicarage Garden}

be passed by with an averted eye. I am told they represent rich mosaics, or Oriental carpets. If that is the object, and if we are to have mosaics and carpets on our lawns, I should prefer a bed of encaustic tiles, or a carpet. This would produce the same result with less labour and less expense, and at times would be useful.

But I have spoken too much on this. My subject is the mixed garden, or the garden of mixed borders. The name is a modern one, though the thing is old. It is, in fact, the facilis hortus of Martial, which he contrasted with the villa :-

"Otiosis ordinata myrtetis,

Viduaque platano, tonsilique buxeto."-III. 57.

and an amusing description of one, in which the principle is carried out to an absurd extent, is given in the Spectator, No. 477. (The supposed writer says he is one who is looked upon as a humorist in gardening.) The name is a modern one, because it was found necessary to invent some name which would show that the garden was no longer wholly given up to bedding-out, but it has different meanings with different writers, and by most it is taken to mean a border of large herbaceous plants (usually a shrubbery border) in which old-fashioned plants may be allowed a home, but on which very little care or thought is spent, while the real labour of the garden is given to the smart and formal portion 


\section{The Mixed Garden}

where the bedded-out borders are in all their splendour. Such is not my idea of a mixed garden. I mean a garden which is entirely made up of mixed borders, except in the case of very large places, where a formal garden may somewhere easily find its fitting place. And such a garden may be of any size, from the three hundred acres or more at Kew (probably the finest mixed garden in Europe), to the small square that forms the back garden of most suburban villas. But whatever the size, the less formal it is, and the less uniform in the positions and shapes of the different borders the better. Milton described the river of Paradise as-

"Visiting each plant, and fed Flowers worthy of Paradise, which not nice art In beds and curious knots, but nature boon Poured forth profuse ;"

and Sir Henry Wotton laid down the rule that there was " a certain contrariety between building and gardening; for as fabricks should be regular, so gardens should be irregular, or at least cast into a very wild regularity." It is this "wild regularity" which forms to my mind the real charm of a good mixed garden; and it is this, and not the large collection of different plants in it, which distinguishes it from other gardens, because plants grown in such a way may be allowed to grow in their fullest vigour, and to develop each its own shape, colour, and character, without any fear of its transgressing the lines of 


\section{In My Vicarage Garden}

any well-devised plan, because there is no such plan to which they must conform.

My ideal of a good mixed garden is one in which the borders are always full, in which there is no repetition, so that there can nowhere be found one yard like another, and which in every month of the year and in every week can show a different set of plants in flower. Of such gardens we have already good and pleasant records in Miss Hope's Gardens and Woodlands, in Bright's Year in a Lancashire Garden, in E. V. B.'s Days and Hours in a Garden, and in other books; and all of these are records of gardens of limited extent. My own garden, including everything, is less than two acres, and I have very little glass, so that almost everything must be hardy; and yet there is no difficulty in carrying out the principles I have just laid down. Every border must be full; and for this purpose no border is given up to any one class of plants; there is a mixture of shrubs, herbaceous plants, bulbs, and ferns all joined together, without any respect to uniformity of outline, or fancied harmonies in colour, or studied variations in heights, but each placed where it grows, because that particular place was supposed to be best suited to its wants, or sometimes for no better reason than to fill a vacancy. But even when thus filled blanks will often occur. Spring bulbs will die down, and early summer flowers will require to be cut down even where they do not disappear after 


\section{The Mixed Garden}

flowering; and the greenhouse plants then become most valuable. Geraniums, begonias, heliotropes, calceolarias, verbenas, etc., fill up blanks in the most satisfactory way, and most of them having very small roots can, with a little care and much watering, be transplanted to where they are wanted all through the summer; begonias especially are most kind and patient under such treatment, and can be removed from one place to another with very little difficulty. Annuals are equally useful for the same purpose, and many of them are very beautiful, but they are not so patient under removal.

But I can best illustrate my meaning by giving an example; and I will give it from my own garden, not boastfully because mine is better than others of the same sort (I have seen many that far surpass my own), but because I can write more correctly from the example close before me. I am fortunate in having a long wall facing south, and I am fortunate in having a good alluvial soil, though too full of lime to allow me to grow many plants which otherwise I should like to grow. In front of this wall I have a border about eight feet wide, edged with rough stones placed on, and not sunk in, the ground. I will take about a dozen or fifteen yards, which I suppose to be about the length of the front borders in most of the detached suburban villas. In this distance trained to the wall I have Plagianthus lyalli, from New Zealand; Fremontia Californica; 


\section{In My Vicarage Garden}

clematis coccinea, from Texas ; Budleia Lindleyana, with trusses of curious purple and grey flowers, from China; abuliton vexillarum, from South America; and physianthus albens, from Buenos Ayres. Close under the wall, but not trained to it, are the so-called Australian daisy, which, however, comes from Mexico; the beautiful Caper plant (capparis spinosa), from South Europe, which requires an exceptionally fine summer to flower; crinum capense and Powelli, from the Cape of Good Hope; opuntia, from Brazil ; amaryllis ackramanni, the most gorgeous in colour of all amaryllises, also from Brazil; teucrium fruticans, from south of Europe; and fuschia excorticata, a very curious species, from New Zealand. In the border are yucca angustifolia; olearias from New Zealand; Arum Jacquemonti, a remarkable hooded arum from the Himalayas; cercocarpus, a shrub from (I believe) South America; and some cistuses, aguilegias, penstemons, etc., while the edging is taken up with different sorts of iberis, Iceland poppy, aubrietia, lychnis, teucrium aureum, sempervivum, sedum, saxifrage, and I say nothing of some of the commoner plants, or of the spring bulbs which are dormant and unseen. This particular length of border is no better than any other part; indeed I could have selected some parts which would contain more, and perhaps more interesting, plants. I only choose this as showing how in a very small compass a great variety may be 


\section{The Mixed Garden}

gathered together from all quarters of the world, varying in their time of flowering, but so arranged that the border is never dull or empty, but can at all times of the year show something that is interesting not only to myself or to a botanist, but also to unbotanical friends and visitors.

To such borders two objections are commonly made. They are said to be untidy; but they need not be so; and one-tenth of the care required for a large bed of geraniums would be sufficient for a much larger mixed border. They are said, too, to be lacking in colour, or to have their colours mixed together without harmony. The lack of colour depends on the plants selected ; there are plenty of bright flowers to be found. The want of harmony in colour I deny. Plants whose flowers will not (theoretically) harmonise may be planted in close contact, if only they are allowed to grow naturally. The colours of the flowers in a field or wood or hedgerow or Swiss pasture are mixed together without any respect to the laws of colour-harmony-yet there is no discord; the green leaves and the green grass sufficiently guard against that-the herbescens viriditas (Cicero's happy phrase) harmonises all. 


\section{CHAPTER VI}

\section{A BACKWARD SPRING}

I CANNOT recollect so backward a spring as the present $;^{1}$ everything in the gardens and the fields is a full month, and in some parts quite six weeks later than the usual time. It is now the first week in April, and instead of being able to say with Gonzalo, as we can in ordinary years-

"How lush and lusty the grass looks! How green!"

we see nothing of colour in the fields but a dull, uniform, dirty yellow. This has come not only or chiefly from the bitter weather of December and January, but still more from the second winter of March. The few bright days that we had in February caused some plants to start into growth, but the nights were too cold to allow of much growth, and then came the fearful blizzard week, followed by much cold all through the month of March; and that second winter seems to have been more disastrous to the gardens than all the bitter weather of December and January. And so it has come to pass that the fields are bare; there were very few primroses for Easter, 1 Written in 1891 . 


\section{A Backward Spring}

and as for the daffodils, they did not justify their name of Lent lilies, and are still very scarce. Their proud boast that they-

"Come before the swallow dares, and take The winds of March with beauty," 1

will scarcely hold true this year. Probably the swallows will be late, but they are often seen in the first week of April, and some will even dare a few days sooner; but with the exception of a few of the wild daffodil ( $N$. pseudo-narcissus) and its varieties, the narcissi are not yet even showing their buds, and in some sorts the leaves are only just above ground. I suppose, however, that Shakespeare was thinking of the wild daffodil, and so he still is right.

Yet the garden is not all barren. The kitchengarden is sadly bare, and I hear on all sides that the market-gardeners have grievous losses; but the flower-garden even now has many beauties, and a walk round the garden can give much pleasure. Let us look at the shrubs first; there are not many in flower, but what there are are very welcome and interesting.

Banksia roses are barely showing their buds. I have often had good bunches even at an early Easter; but the Forsythia suspensa is fairly in flower, and I know of no shrub more to be recommended as a spring-flowering shrub than this Japanese climber. It is perfectly hardy, so

${ }^{1}$ The swallows came on April 5, and the daffodils had then made no progress. 


\section{In My Vicarage Garden}

hardy that it does not require a wall, and would probably do well trained up a tree; but it deserves a wall, and being a fast grower it will very soon cover a large extent of a high wall. The beauty of it lies in its long, graceful wreaths of golden flowers; wreaths six feet long are not uncommon, and after the flowering it should be pruned, and then it has a good appearance all the summer. Close by in a sheltered corner, but not trained to the wall, I have the Japanese hawthorn, Photinia serrulata. It is not in flower; it seldom flowers in England, but I value it for its beauty in spring. At all times it is a handsome shrub, with its bright, shining leaves (hence its name), but at this time of the year the young shoots at the ends of the branches are of a deep crimson colour, so that at a little distance the shrub looks like a fine flowering shrub with its flowers half-expanded. Then there is the Rhododendron Davuricum, one of the earliest shrubs that flower in the open ground (the cheimonanthus and the Lonicera fragrantissima are earlier, but require a wall). This is a shrub well worth growing. It is supposed by some to be a geographical variety of the Alpine rose ( $R$. ferrugineum), but for garden purposes it is very distinct. Coming from Siberia, it is perfectly hardy, and is not so particular about soil as other rhododendrons; but I cannot say it is so pretty, as the flowers stand singly at the ends of the branches, and the whole plant has rather an untidy habit; but the flowers come very 


\section{A Backward Spring}

early (it has been in flower here quite six weeks), and the leaves are covered with curious glandular dots, which make them pretty objects under the microscope. Another shrub or small tree that much interests me is the Parottia Persica, from the Eastern Caucasus, and apparently as hardy as an elm. It is one of the most beautiful shrubs for autumnal foliage, but it is interesting also for its flowers, which appear in this month or earlier. The tree does not flower till it is of some age, but then it seems to flower freely, and the flowers are curious and pretty. They are little balls about the size of a nut, composed entirely of bright crimson anthers. On my own tree there are only these male flowers; the female flowers I have not seen, and know nothing about them. Close to this I have a shrub of the Cornus Mas. Mine is the variegated form, and it is usually grown for the sake of the variegated foliage, and deservedly so, for sprays of the short branches are excellent for picking, as they last a long time, and are bright and clear in colour. I have found them very useful for altar vases, but at present there are no leaves, yet the shrub is pretty from the multitude of little golden starry flowers with which it is covered. The Garrya Elliptica is very shabby this year, and it would be difficult to gather a good catkin from it, so I pass it by. The Daphne Mezereon is in full flower, and where it does well a large bush is a pretty object, and the scent of the flowers is delightful; but I have never suc- 


\section{In My Vicarage Garden}

ceeded with it, though it grows easily in many of the cottage gardens of the neighbourhood. This exhausts the flowering shrubs now in flower, with the exception of the peaches and nectarines, which I think we should grow for their pretty flowers, even if there were no fruit to follow, and with the exception of one other which deserves a paragraph to itself.

I have on my lawn an old circular bed permanently planted with a broad band of the diwarf S. European heath, Erica carnea, and inside that another band of the old yellow crocus, the remainder of the bed being carpeted with the beautiful leaves of the autumn cyclamen, $C$. hederaefolium. In summer the centre is gay with an old plant of fuchsia globosa, and some Japanese maples. The heath and crocus in ordinary years would have passed away long before this, but they are still in great beauty, and have been for some weeks; the heath was in blossom in the beginning of February. I wonder this heath is not more grown. As far as I know, it will grow in any soil; it is very inexpensive, and if cut in close after flowering it forms a rich green cushion all the year. To bees, too, it is very attractive; I always see on it the first bees of the year. I am sorry to say it is equally attractive to pigeons. Two years ago the pigeons ate off every bud as soon as it appeared, yet last year and this year they have not touched it; and why they should have stripped it one year and 


\section{A Backward Spring}

left it untouched the next is a puzzle. And I mention the bed because it is a good instance of a bed kept for many years in beauty, with very little trouble. The crocuses must have been there more than twenty years; the heath has to my certain knowledge grown there for more than forty years, while the original cyclamen plants from which the rest have spread were planted in 1817.

I will now go to some of the herbaceous and bulbous plants in flower. These have fared much better than the shrubs, having been for six weeks completely covered by a thick blanket of snow. During that time I think the ground was never frozen. I did not try it with a thermometer, but I often thrust a stick through the snow into the ground, and I always found it soft and unfrozen. I pass by the daffodils, except to say again how thoroughly they have this year belied their traditional character, which all our poets have loved to dwell on. Many may like to renew their acquaintance with one only, Aubrey de Vere, whose exquisite ode to the daffodil begins :-

"O love-star of the unbeloved March,

Thou comest when first the spring

On winter's verge encroaches :

When gifts that speed on wounded wing

Meet little save reproaches."

and ends :-

"To-day the spring is crowned a queen, but thou

Thy winter hast already; 


\section{In My Vicarage Garden}

Take my song's blessing and depart, Type of true service-unrequited heart ;"

for it seems likely that the daffodils this year will almost last into the summer. Nor must I stop long with the Christmas roses. There are still a few of the true ones (helleborus niger), but they are poor and ragged, and I have scarcely picked a good one all the winter. Yet they always have their interest. I have been looking into their history, and I cannot believe that our white Christmas rose is the Hellebore of Theophrastus and Pliny. It differs in many respects, and is not found at Anticyra, and I think their Hellebore is our Veratrum. Yet all the old writers identify it with the classical plant, and speak very positively about its virtues; though they seem to have little ground for the belief beyond the "signatures," which taught them that a plant with black roots must be good for the black bile, melan-cholia. Burton, in his Anatomy of Melancholy, has a long chapter on the plant, and evidently believed in it as a cure for melancholy; and Cole, in his Adam in Eden, I657, goes still further, affirming it to be not only "effectual for melancholick, dull, and heavy persons, as questionless it is by signatures," but further " neither is it without great efficacy to cure those that seeme to be possessed with the Devil." These virtues it has long lost or never had; it is used as a medicine in some parts of Europe, but is not admitted into the English Pharmacopœia. 


\section{A Backward Spring}

But if the true Christmas rose has failed this year, the hybrid varieties have been loaded with flowers, and I admire them much. They lack the pure beauty of the Christmas rose, but their great flowers have been well compared to gigantic apple-blossoms. They will not bear picking, or if picked they soon fade, but the leaves that come after the flowers are very handsome; and a large clump makes almost an evergreen bush; and as the leaves, unlike the flowers, last well in water, they are very useful among cut flowers. Another plant, also named from its "signatures," is the Hepatica, or liverwort ; though its likeness to any part of the liver is very far-fetched. It has no value in medicine, and even by Cole "the noble liverwort is prized more for pleasure to the senses than for helping any disease," and "for pleasure" they are most valuable at this time of year, though Parkinson puts them among the flowers of January. They are too well known to require any description; I would only say of them that it is well never to disturb them; the older the plant the better will it flower; and I would mention one curious point - that while the single flowers are among the easiest to cultivate, the double blue is in many gardens almost an impossibility, and the double white is so rare that many doubt its existence. I never saw it, but I was assured by the late $\mathrm{Mr}$ Wheeler, of Warminster (an excellent gardener, and one of the few nurserymen that are accurate botanists), that it only occurs as the 


\section{In My Vicarage Garden}

autumnal form of the single red. And a third plant, also named for its "signatures," is the lungwort, or Jerusalem cowslip (Pulmonaria), which is now a great ornament in the garden, and has always been a special favourite in English gardens. There are many species, but none more beautiful than the British $P$. angustifolia, which is found in the Isle of Wight and in some parts of South Hampshire. I found it once near Beaulieu, in the New Forest. Nor must I leave unmentioned the lovely dog's tooth violet, now in great beauty, and certainly one of the most graceful ornaments of the spring garden in its different colours of pink, white, or yellow, and as easy to grow as a crocus. And when I have named the spring cyclamen (C. Coum), which still carries a few flowers, and a few anemones where there ought to be a multitude, I think I have nearly exhausted the list of herbaceous plants now in flower, though in most years April would be able to show many more.

Of bulbs there are not many in flower, but the few are gems. Snowdrops and crocuses have almost passed away, and in ordinary seasons would have quite disappeared, and, as I said before, the daffodils are only just beginning to appear. But the squills are at their best, and I don't know which to admire most, the blue or the pure white. The white is one of our best spring flowers, and a good clump with its shiny white stars is very attractive. It likes to be let alone 


\section{A Backward Spring}

and so do all the squills; indeed, I have never been convinced of the good of constantly taking up and drying my bulbs ; in some soils it may be necessary, but I think it is entirely a question of soil. The grape hyacinths are also now in flower, most of them not so bright in colour as the squills, but the white variety is very pure. The chionodoxas increase in beauty as well as in number every year, and this year they are especially fine, but I will say no more of them now, except that their complete hardiness has been well proved this winter, for they pushed up their lovely flowers through the snow.

Certainly, in spite of all we have gone through, the garden is not barren, and, like everything else in this world, the bad weather has, to some extent, brought its own compensation. If we had a flowerless February and March, the flowers have not been lost, and we are having them now, and shall probably see in May many more flowers than are usually seen in that month. The prospect is really very hopeful; judging by the plants that have already flowered, and by the buds that are now appearing, it seems likely that there will be an abundance of flowers; and for that we shall be indebted to the growing summer and brilliant autumn of last year, and perhaps in some measure to the retarding power of the long, severe winter. I do not pretend to be a weather prophet, but if we can put any trust in averages and proverbs we must expect a wet summer, which will not be 


\section{In My Vicarage Garden}

without its use to the plants that have been badly injured by the winter and are making a struggle for life. The old proverb says-

" There is no debt paid so nigh

As the wet pays to the dry ;"

and taking the twelve months ending the 3 Ist of March there is a debt of twelve inches of rain. But all this is uncertain; and does not this very uncertainty form one of the chief pleasures of gardening? It would be tame work if it wás always successful and if we could have it all our own way. And is it not our uncertain and much-abused English climate, with all the difficulties and disappointments that it brings with it, which has made our English and Scotch gardeners among the very best in the world? 


\title{
PART II \\ ELSEWHERE
}

\author{
VARIOUS
}





\section{CHAPTER VII}

\section{SUNSHINE AND SHADE IN THE GARDEN}

I AM sure that half the science of gardening consists in knowing where to place different plants. A man may receive a bundle of new plants, most of which he may never have seen before, and it may easily be a sore puzzle to him to decide in what places it would be best to plant. The gardener of much experience, even if he may not have had to do before with the particular plants sent, will yet, by a sort of intuition, be able, by the appearance of many of them, at once to decide on their right places; but it requires a long experience, and the longest experience will sometimes make mistakes. The beginner finds himself face to face with a real difficulty. $\mathrm{He}$ may be told the country from which the plants come, but that very often will not help him much ; and he may be told that some are quite hardy, while others are more or less tender, but even that does not solve his difficulties. He wishes to do the best he can for his new arrivals, and he determines that they shall have all the advantages that a good position will give them; but he often makes fatal mistakes, and one of the first that he will be sure to make will be to place many of the 


\section{In My Vicarage Garden}

tender plants in the brightest and sunniest place he can find-it seems to him nothing but natural kindness to do so. But he soon finds out his error; the tender plants may be so tender that they cannot stand the full blaze even of an English sun; and though they may be subtropical, they ask to be protected from bright sun. In their own country they may have a warm, perhaps a hot climate; but the fact is that a very large proportion of our exotic plants are in their own countries wood plants. This is markedly the case with the plants of Switzerland and other parts of Southern Europe. They are found wild in woods chiefly, many of them in the open glades, but many also in the dense shade of the fir woods.

How such plants seek for shade and protection can be seen in the nearest hedgerow. An old hedgerow is a close mat of plants of all sorts with scarcely a single open space; the whole surface is covered with brambles, nettles, deadly nightshade, dead nettles, and many others, and yet through the thick mass, and nestling under the most unlikely bushes we find delicate flowers of many sorts growing vigorously, and apparently most happy in their surroundings. And even wild plants which are not in hedgerows, but grow in the open fields and meadows, apparently exposed to the full blaze of the sun and the full blasts of cold wind, are yet largely protected by the herbage among which they grow. Their 


\section{Sunshine and Shade}

roots are protected; the close herbage prevents a rapid evaporation of moisture, and the roots, except in a very prolonged drought, are kept cool and moist. High Alpine plants give a very good example of this. Many a plant-lover in his search for the distinctly Alpine plants comes upon or sees at a distance a bare-looking hillside in which it seems hopeless to search for any good plants. But perhaps it is these unpromising-looking places that will yield him the richest harvest. I had a good lesson in this point in the Tyrolese Dolomites, going from Predazzo to San Martino by the Rolle Pass; where about a mile or more on each side of the top of the Pass, was a very barren-looking Alp which seemed as unlikely a place for good plants as possible. But from its elevation ( 6600 feet) and other appearances, I felt sure it would be worth a visit, and I went to it more than once. It was a carpet of high Alpines; it will be enough to mention ranunculus thora and rutifolius, phyteuma serratum, erigeron uniflorus, veronica bellidoides, soldanella alpina, and many others, including rare saxifrages and gentians and a curious carpet of Edelweiss, not two inches high and almost stemless; while a little higher up was potentilla nitida and rhododendron chamocistus, and the whole Alp was thickly set with arnica montana, which in a short time would be a mass of gold. Now all these plants were fully exposed to sun and wind, but not one of them was standing alone in a place all to itself; they 


\section{In My Vicarage Garden}

were growing out of a turf of short grass, which, though short, gave protection and shade to the roots.

The same lesson of the value of shade and protection was taught in other ways. One of the most graceful of the clematises, and, as I think, quite the most beautiful of all wild climbers, is the blue atragene alpina. It is abundant in Tyrol, but it is always growing amongst the fir trees, up which it loves to climb. Another lovely plant that always rejoices the heart of the man who sees it wild for the first time is the ladies' slipper (cypripedium calceolus). I saw this abundantly near San Martino, and, wherever I saw it, it was forcing its way through the lower prostrate boughs of pinus mughus; it is, I know, found in other positions, but it was only in that position that I found it. It was the same with the aquilegia alpina, of which I found several at Piora ; but in every case the flower was coming through the alpenrose. It is quite possible that in both these cases the plant would grow elsewhere, but the pine and the alpenrose protected them from the cattle and the goats; and it showed that such places were quite fitted for their perfect growth. The same thing often occurs in gardens; every gardener knows how apt weeds are to come up in the very midst of his pet plants ; groundsel delights in the close neighbourhood of other plants; and the wild violet and the dandelion have a most objectionable habit of sowing them- 


\section{Sunshine and Shade}

selves in the centre of good plants, from which it is often difficult to get rid of them. In these cases, too, it is possible that the seed is sown elsewhere also, but those sown in the middle of other plants are protected from or overlooked by the birds, and so come to the perfection which we do not ask for. But beyond protection given by one plant to another, I feel sure that all plants are more parasitical than we are generally inclined to fancy. I do not mean that they are parasitical in the same sense that the mistletoe, dodder, broomrapes, toothworts, and epiphytal orchids are parasites, actually living on, and in many cases destroying, their hosts; but they are parasites in the sense of the better class of Greek and Roman parasites, not necessarily sponges, but with a liking to live in company; they dislike solitude.

Indeed, the whole subject of protection to vegetation is curious and far-reaching, and I saw a remarkable instance of it lately. In I 899 there was a very remarkable landslip at Airolo, which practically brought down a large side of the mountain, exposing a bare surface over a great extent. I saw it in 1900, and it was curious to note that in some parts fir-trees were standing upright on the bared soil, even in large patches ; but wherever these patches occurred, the trees had been saved by the presence of a rock more or less large, the size of the rock determining the size of the saved patch below it. Now this meant that 


\section{In My Vicarage Garden}

in those patches vegetation will regain its full power many years before the unprotected patches, and the value of protection will be proved for generations.

To bring this matter into practical gardening. It is now perhaps forty years or more since the discovery was made that the best, perhaps the only sure way, of growing Lilium auratum was to grow it among bushes, especially rhododendrons, and the same thing is now found to be the best way of growing bamboos, which rejoice in shaded roots with a power of bringing their long shoots into light and sunshine. The same rule, also, is found to hold good with many tender shrubs; nearly all the Chilian shrubs, and many others, are found to grow easily on a north wall, i.e. a wall facing north, and will perish on a south wall; I mean especially such plants as Lapageria, Tricuspidaria, Solanum jasminoides, Ficus repens, Stauntonia, Mitraria, and many others. And in all the best gardens the value of shade and protection is now fully recognised. At Kew there are many very attractive beds composed of one shrub, and with lilies and other plants coming up in their midst. Mr Wilson's celebrated garden at Wisley owes, I think, the greater part of its success to the abundance of shade which he is able to get in his wood. In Miss Jekyll's equally celebrated garden at Munstead the most interesting parts are those in which she so cleverly cultivates her plants in a thin wood. It has come to be recognised that a garden without trees and 


\section{Sunshine and Shade}

shrubs is not only ugly in itself, but it loses the great help in the cultivation of plants which trees and shrubs will give.

I do not mean to say that gardeners should avoid putting their tender plants in the sun altogether, and there is one class of plants to which I would give all the sun I could find for them. These are the early spring flowers. In their own country they may be wood or marsh plants, but with us they are all the better for, and fully deserve, the sunniest spots we can give them. I mean such plants as the spring cyclamens, early irises, crocuses, snowdrops, etc. But the point I wish to bring out is not only that a shady garden is not a garden in which gardening can only be carried on under difficulties, but that shade and protection, whether from trees, shrubs, or walls, are great helps to the gardener, and that without them it is really hopeless to make the garden a thing of delight.

The old writers, and some modern ones, have loved to moralise on the beauties of living under the shadow of a protecting power. Spenser has a short fable about a bramble that resents the neighbourhood of a great oak; but when the oak was cut down he was "naked left and disconsolate" and died ; and Shakespeare says :-

The strawberry grows underneath the nettle,

and draws a moral. But the moral is too obvious to require me to dwell further upon it.

E

65 


\section{CHAPTER VIII}

\section{CARPET PLANTS}

I WISH to say something more on the "Carpet Plants," which I mentioned in my paper on the Flowers of Spring. ${ }^{1}$ A short paper will be enough for the purpose.

By carpet plants, I do not at all mean the plants that generally compose the so-called carpet beds. These beds are, in my view, the worst form of summer bedding, being generally composed of stiff, parallel or concentric lines of sempervivums, echeverias, and other plants, so arranged as to give the impression of a small carpet or rug. They are dearly loved by many gardeners-even many good gardeners-and are the especial delight of nurserymen; but I cannot admire them, while I do very much admire a good use of carpet plants. For these carpet plants the following points are necessary: they must be evergreen, that is, they must not only clothe the ground in summer and autumn, but all through the year; they must be of a soft, tender nature, so that such bulbs as snowdrops, crocuses, squills, chionodoxa, etc., and such plants as ane-

$$
1 \text { P. } 4 .
$$




\section{Carpet Plants}

mones, and dog's-tooth violets may come up through them without doing or receiving injury; they must be very close-growing, shallow-rooted, and spreading in every direction without laying bare their centres. There are many such plants, but they have to be well chosen and carefully looked after. The ideal carpet plant for English gardens is our lawn grass; it is the plant that makes all the difference between English and continental gardens; but it is only good as a lawn plant; if allowed to wander into the flower beds it very soon becomes a pestilent weed. Not only has it the habit of placing itself in the very midst of good plants, and so choking them, but, like all other grasses, including the bamboos, it is such a gross feeder that it soon takes to itself all the moisture and good food that it can reach; so as a carpet plant for the flower beds it is worse than useless.

About forty years ago a plant was introduced which promised to be not only a rival of the grass for lawns, but also a beautiful carpet plant in our borders. It was a Sagina, but whether $S$. procumbens or $S$. pilifera I am not sure. It was first grown to a large extent in a garden at Sydenham, and there I saw it. The garden was a small one of the usual suburban type, enclosed by the house and three walls, and, as far as I recollect, the whole space was carpeted with this Sagina, and a most beautiful carpet it made, having such a likeness to a rich green velvet-pile 


\section{In My Vicarage Garden}

carpet that one felt almost loath to tread on it with dirty shoes, and of an even texture throughout, nowhere above half an inch high, and with no vacant spaces. It had a rapid sale, but it was soon found to degenerate, and in many cases to die completely, and I have never since heard of its being used either as a carpet or as a rock plant. About the same time another plant was introduced with the character of being a perfect carpet plant. This was the Chrysanthemum or Pyrethrum Tchihatchewii, from Russia, and though not so close in habit as the Sagina, it was undoubtedly a plant that in some places might be useful, where a coarse carpet would suffice. But it soon proved itself to be very capricious, doing fairly well in some gardens, but refusing to grow at all in others, and it was, I believe, found to be useless under or even near trees; so it had to be given up, though where it grows well it makes a very pretty rockwork plant.

But there are many plants of real beauty which make beautiful carpet plants, answering all the conditions that I have laid down. I place among the very best the Campanula Portenschlagiana, from Dalmatia. It is so perfectly hardy and evergreen that I never knew it the least injured in the hardest winter; and with me it keeps a uniform height during the winter, not above two or three inches, and without any bare, brown places. Then, in the summer, it is a mass of 


\section{Carpet Plants}

lovely pale blue flowers, which last a long time, and it does not object to a crocus or two coming up in its midst, though it would not like a thick mass. Altogether, I think it one of my most useful plants for growing in full sun, and though I call it a carpet plant, it is excellent also as what I may call a curtain or tapestry plant. I know an old brick kitchen-garden wall in Devonshire on the top of which a plant of this campanula had found a suitable home, and from the top of the wall the plant has spread downwards, rooting and sowing itself in every coin of vantage till it has covered the wall for several yards in length.

I reckon many of the acænas among good carpet plants, if only the winter is not too severe; but in a very severe winter the plants are apt to become bare in places and so lose their beauty for a time, but they generally recover it soon, and one of them $A$. pinnatifida will generally be a close green carpet through even a hard winter. These acænas are mostly from South America and New Zealand, and are of very various colours, one very hardy one, $A$. inermis, being of a decided slate colour; and they all produce burs, with thorns of different shapes, but all more or less clinging to anything that touches them; and it is on account of these burs that the plants get their name from the Greek "ँx $x$ เva, a thorn or goad.

I have not space to speak of many other good 


\section{In My Vicarage Garden}

carpet plants, and can do no more than name a few. The mossy saxifrages are more cushion than carpet plants, and are very apt to get brown patches which are unsightly. All the thymes are good for the purpose, especially the pure white and the dark red. Arenaria Balearica is a firstrate carpet plant for stones in damp places, but it is somewhat difficult to establish. Hutchinsia Alpina makes an excellent dark green very close carpet, and when covered with its pretty pure white flowers is one of the best flowers of spring. Many of the low-growing Veronicas, especially $V$. repens, are almost as good, and I will close the list with Herniaria diandra, which, though only an annual, will often cover a considerable space, and keep green all the winter.

This, of course, is not a complete list of the many good carpet plants that we may use, but it will be enough to show that we have many good plants which will cover the ground for us, and soon make a brave show of greenery at all times. There is one point in the cultivation of these plants which may be worth mentioning. A good carpet cannot be made in one season, even by planting several plants together, for I have found by experience that one plant allowed to spread and increase in its own natural way makes the best mass in the end. Gardeners are often too apt to try to get perfection at a stroke; they 


\section{Carpet Plants}

would like their gardens to be "like Adonis' gardens,

That one day bloomed and fruitful were the next," Henry VI., Act I, s. 6, but for permanent good results such haste does not make good speed, or good work; and in the end patience wins the race in gardening as in so many other paths of life. 


\section{CHAPTER IX}

WHILE THE GARDEN IS UNDER SNOW

FOR nearly a month the garden has been completely closed; in such a December as we have just been passing through all out-of-door work is necessarily stopped. ${ }^{1}$ Yet the gardener is not, therefore, entirely without work, or without even pleasant work, and if he is fortunate enough either to have a good botanical library himself, or to have ready access to one, his time may indeed be pleasantly occupied, and in a way which will bring good results when he can again take up his usual work.

I suppose no one who loves his garden is entirely without books on his favourite subject; and, indeed, I have always found that a lover of gardens and flowers is also more or less a lover and reader of books. In our country villages the chief applicants for books from the lending library are the gardeners, and the more they love their gardens and their flowers the more they wish to read about them; and the more they get to know from books the more they desire to know; and when cut off from their gardens by snow and

${ }^{1}$ Written in January $\mathbf{1} 89 \mathbf{1}$, but altered in some places. 


\section{The Garden under Snow}

frost they still find plenty of employment and pleasant work in reading of their favourites; and the best gardeners are the greatest readers, for Sir Thomas Browne's saying holds good with gardening and botany as much as in other pursuits, "They do most by books, who could do much without them."

And the gardener has no lack of choice. $\mathrm{Mr}$ Baydon Jackson in I88I put the number of botanical works then existing at over eight thousand; since that time the number has been much increased; and as several of the works are in many volumes there must be certainly over ten thousand volumes now to choose from. Many of these are sumptuous books of great price, such as Sibthorp's Flora Graca, which is said to have cost $£_{\mathrm{I} O, 000 ;}$ and some are of excessive rarity, such as Rudbeck's beautiful Campi Elysii, of which only one perfect copy is known, now in the Sherardian Library at Oxford. Such books can seldom be seen out of public libraries; but we have many such libraries in England, and there are probably few better botanical libraries than can be seen any day at Kew, or at the South Kensington Natural History Museum, or at the British Museum, or in the Lindley Library, in charge of the Horticultural Society. But the gardener wants books of his own, that he can study by his own fireside, in the long winter evenings, or when all outside work is stopped by frost and snow. He will be fortunate if among 


\section{In My Vicarage Garden}

such books he can reckon the Botanical Magazine, for I should consider it as almost, if not quite, the first work to be desired in a botanical library. With its 127 volumes, containing 7800 plates of flowers, it is a library in itself; and though its early volumes are more than a hundred years old (it commenced in 1787), yet it has always been conducted on the same lines, and the older volumes are especially interesting. Mr Bright, in his Year in a Lancashire Garden, records for his December work :-

We have been looking over old volumes of Curtis's Botanical Magazine, and have been trying, not always successfully, to get a number of old forgotten plants of beauty, now of rarity.

It has been my good fortune always to have had access to Curtis, and it has been my pleasure, too, to hunt up in it the old plants which were a pleasure to our fathers and grandfathers; and I never look through a volume without learning something new. The entire work is expensive, and not easily procured, but the fifty-two volumes of the first series can be bought cheaply, and odd volumes are often on sale for very little, and as each volume is complete in itself, I know of few more useful books to give to a young gardener than a few volumes of the Botanical Magazine.

Another excellent book of about the same age is Miller's Gardener's Dictionary, a book often seen on the bookshelves of good libraries, but not often read. Yet it is full of information from 


\section{The Garden under Snow}

beginning to end, and I know of no book so useful in its particular way. For the history of the plants and the old plant names given by the older writers it is most valuable, and the cultural directions are excellent. Though the last edition in four folio volumes was published nearly a hundred years ago, I know of no book that has supplanted it as a botanical and gardening dictionary, and, as it can be bought for a few shillings, I can safely recommend it to all.

Different gardeners will, of course, be attracted by different books. Some will only be satisfied with purely scientific botany; others will be attracted by books treating of geographical and geological botany; others will only care for books which tell how to grow and improve flowers; and each and all will find abundance of books to their different tastes. My own taste has always been for the old writers, especially those of the seventeenth and early part of the eighteenth centuries; and without denying the excellent work done by many foreign writers of that date, I have always taken a special delight in our own English writers. There were many English writers on botany before Gerard; but his work is really the first English work that popularised botany. It is not truly an English work, for it is a translation from Dodoens, and the plates are taken from Tabernaemontanus. Still there is a great deal of original matter, and the English is Gerard's own, and is very quaint and 


\section{In My Vicarage Garden}

pleasant reading. The drawback to one's pleasure in reading him is that $I$ am afraid he was not an honest man. His method of compiling his book was not honest, and his editor, Johnson, often corrects him, and not to his advantage. Thus Gerard, in his account of the pœony, says that he found it wild "upon a conny berry in Betsome, being in the parish of Southfleet, in Kent, two miles from Gravesend, and in the ground sometimes belonging to a farmer there called John Bradley;" but Johnson says :-_ "I have beene told that our Author himselfe planted that Peioniee there, and afterwards seemed to finde it there by accident." For this reason, among others, I much prefer Parkinson. His Paradisi in Sole Paridisus Terrestris (i.e. "Park-in-son's Earthly Paradise") is altogether a delightful book, and from beginning to end there is a thoroughly honest ring about it. You feel that he is telling you nothing about his plants but what he has himself seen or done, and the woodcuts are drawn from the living plants, without the least exaggeration. The collection of plants in the two books, the Paradisus and Theatrum, is really a wonderful collection, and his descriptions of them are given in strong vigorous English which leaves nothing to be desired. Take his description of the seed vessels of the Pœony, which I have just named; first, however, taking a modern botanical description of the plant, "Follicles 2-5, downy recurved, with many seeds and covered 


\section{The Garden under Snow}

with the bilamellated stigmas." This is quite accurate, but Parkinson gives us an exact portrait :

"The seed vessels are divided into two, three, or four rough crooked pods like hornes, which, when they are full ripe, open and turn themselves down one edge to another backwards, showing within them divers round black shining seeds, which are the true seed, being full and good, and having also many red or crimson grains, which are lanck and idle, intermixed among the black, as if they were good seed, whereby it maketh a very pretty show."

I should like to stay longer with Parkinson, but space forbids, and there are many other writers of the same date all worth consulting, if only to see the flowers that were then most grown and prized; but there is rather a monotony among them, and they are all to some extent spoiled by the large admixture of medical virtues which it was then thought necessary to give in the description of every plant. It was the fashion of the times; if a plant had no medical virtue, it was scarcely thought to be worth growing, and so too often the virtues were invented, and were chiefly grounded on the then fashionable doctrine of signatures. The same desire to force all botany into the service of medicine was shown in the practice of calling botanic gardens physic gardens. The fine old garden at Oxford was so called within the memory of many of us, and the Chelsea Garden still later.

In the early part of the seventeenth century a 


\section{In My Vicarage Garden}

grand style of flower-books became the fashion, chiefly in France and Holland. The books were simply picture-books, but the plates were beautifully engraved on copper, from perfect drawings, the flowers being often of the natural size. I allude to such books as the Theatrum Flore, Florilegium Renovatum, Jardin du Roy, and above all the Campi Elysii, which I have already named. These are fine folios, but there are some others of a smaller size, such as the Hortus Floridus, with exquisite engravings by Crispin de Paas of flowers arranged in their seasons. But I will say no more of these beautiful books, as I wish to confine myself to English works ; but every lover of flowers would do well not to let any opportunity slip of securing these books.

There are two very special pleasures in looking through old books of flowers. One is the pleasure of finding that, except in really very few instances, the same flowers which now delight us were the delight of our fathers and grandfathers. It is almost amusing to read of prizes and first-class certificates being given to plants as novelties, which may be found well figured in the old books. The Campi Elysii is a case in point. There is no reason to suspect the absolute fidelity of the plates, and there are narcissi there equal to or better than any of the fine ones which have been produced in late years as novelties; and in the same book there are many others which are quite lost to us. Another pleasure is the recalling to our memory 


\section{The Garden under Snow}

good plants which we ourselves have had and lost. As I look through the Botanical Magazine, or the Botanical Register, or Sweet's Flower Garden, I recognise many a flower which I once had and prized, and which perhaps I may never have again; but having once had it, I look with double pleasure on the old plate that recalls it. And I knew one good old gardener who loved to tell of the so-called yellow cabbage rose ${ }^{1}$ which when he was young grew upon his vicarage walls; and though he lived to a good old age he never saw the plant again; but whenever he saw the plate in the Botanical Register it all came back to him with something perhaps of regret, but still more with pleasant memories.

Thankful as I am for books at all times, I feel doubly thankful for them in such a winter as this. I am afraid we are all of us too much inclined to say with Shakespeare's Archbishop Scroop, "Past and to come seem best, things present worst," but there is no doubt the present winter is so far one of the worst on record. Shakespeare gives us the proverb, "As humorous as winter," and we know what he means; but in this winter there are no "fitful humours;" it is one unbroken spell of snow and ice. For three weeks I have not seen the green grass of my lawn, and I fear the effects in the garden must be disastrous. Yet there are gleams of hope. The fine autumn had well ripened the wood of all shrubs, and the deep

1 R. hemisphærica. 


\section{In My Vicarage Garden}

snow has protected the herbaceous and bulbous plants, and the frost has come early, before plants had started into new life. And of course the ice and snow have their uses even to the gardener. If he loses some plants, he will have some pleasant surprises in the survival of others, and if he is watchful and careful he may learn much of the effects of frost and how to guard against it ; and so he may be taught many a useful lesson, though he learn it per damna, per cades. We have been spoiled by a succession of mild winters, and were becoming too venturesome. The check has now come, and for the time it is very unpleasant, and the effects may be woeful ; but we shall not therefore give up our gardens in despair :-

"Deus hæc fortasse benigna Reducet in sedem vice." 


\section{CHAPTER X}

THE ROCK GARDEN

PERSONS going to the Alps, and seeing plants growing there in what look like uncongenial places, and then bringing them home and planting them in their good soil and sheltered gardens, are apt to think that they have done all that is necessary to have at home the bright colours and the vigour of Alpine plants which they so much admired in Switzerland. No doubt they have done all they could, but the end is not far off. In new gardens especially, plants sometimes put on a marvellous luxuriance, and we are tempted to think that we shall succeed, and even do better for our favourites than in their native homes; but it does not last long. Little by little they dwindle away, smothered by weeds or by seedlings from their neighbours, and the end is that many of us have to confess that Alpines from the higher Alps cannot be grown except in a few favoured places or under glass. And this is not only the case with the plants of the high Alps; it is equally the case with many other Swiss plants. I cannot grow the Arnica montana; but has any one ever seen it in England growing with anything approaching 


\section{In My Vicarage Garden}

to the luxuriance of growth and brilliancy of colour that it has in Switzerland in July and August? The Astrantia minor covers the rocks and short grass in many places in Switzerland, but I never knew any one who had really succeeded with it in England. Even the Campanula barbata, which covers acres and acres with its lovely blossoms at many different elevations, will do well enough for two or three seasons, and then will gradually disappear. The fact is, as I suppose, that we can easily give our plants the soil they require, but we cannot give them the climate and atmosphere; and climate and atmosphere are of as much importance to their well-being as carefully selected soil.

But the title of my paper is the Rock Garden, and the growth of Alpines is with most people closely connected with rockeries; yet I wish to speak of them not only or chiefly in connection with Alpines, but with many other plants. I do not entirely agree with those who say that nothing is uglier than a rockery, for I have seen many which were not only beautiful in themselves, but beautiful and most useful additions to beautiful gardens. But there are also many, and perhaps the majority, which are absolutely hideous, but even so they are, or may be, useful, and in some form or other every one who wishes to grow a good collection of plants must have them, for in no other way, generally speaking, can he get the protection, the shade without darkness, and the 


\section{The Rock Garden}

uniform moisture that many plants love. Perhaps the best way in which I give my own ideas as to what a rock garden should be will be by first stating what it should not be; when a person clearly knows what to avoid he has more than half learned the lesson of success.

The rock garden should never be near the house; it must always more or less partake of savagery and wildness, and so is quite out of harmony with studied lines of architecture. And yet the most successful rock garden I have known was close to a house in the suburbs of Worthing. The house is the ordinary suburban villa, with a slip of garden in front, and behind the house another garden of the same width as the house, and about double the depth. The whole of this space is filled with what I can only liken to a miniature meadow in front of but rather below the windows of the house, and surrounded with what looks like the entrance to a small Derbyshire dale. Not a portion of the boundary walls can be seen behind the rocks which have been formed out of the rubbish of old houses pulled down in the neighbourhood, and piled up and covered with flowers and shrubs by the almost unaided labour of an old lady and gentleman, both over fourscore. The naturalness of the scene was complete. In no part could you see anything that suggests that it is all artificial, and it is a grand proof of what can be done out of the most unpromising materials, if there is only skill and enthusiasm. But this is 


\section{In My Vicarage Garden}

an entirely exceptional case; the usual suburban villa is not complete without its rockwork, and the rockwork is almost always a triumph of ugliness. The usual process is to make near the front door a heap of earth of some regular shape, generally oval, four or five feet high, and to place stones of different sorts, spar for preference, at equal distances all over the heap. The likeness to a cake studded with almonds is complete, and the initial error is the erection of the rockwork rising out of level surroundings, and wherever the ground is level round a rockwork its artificial character is at once revealed. A still worse form of rock garden finds great favour with the suburban gardener, and this is to cover a bed with blocks of stone, or coloured glass scoriæ, if he can get them, placed at equal distances all over the surface. I saw such a bed once at Southsea, quite bare except for large blocks of coarse coke placed carefully on the surface with mathematical accuracy. Nature is very generous in hiding anything that is ugly, and filling up every vacuum, but she will find it hard to change such a bed as that into a thing of beauty; and I once saw near Chester a noted rock garden of really good design, and one on which much money and labour had been spent, but which was completely spoiled by too great neatness and trimness. Not only was every shrub carefully clipped, but every stone was twice a year thoroughly scrubbed and scraped, so that though it was more than twenty years old when I saw it 


\section{The Rock Garden}

it looked as if made yesterday; nature and time had done all they could to soften its hardness and to clothe its bare surfaces, but the gardener was able to defy them. So here is another rule-to avoid everything that suggests artifice; or even to suggest man's labour. Of course there must be artifice and there must be human labour, but they should be kept out of sight as much as possible.

There is another form of the rock garden which must be noticed; for it is very scientific and very ugly. This is the pocketed garden, which was first started by $\mathrm{Mr} \mathrm{M}$ 'Nab at the Edinburgh Botanic Gardens about thirty years ago. It consists of a collection of squares placed side by side, and one above the other, the sides of the squares being formed of thin flat stones, of which two-thirds at least are below the surface of the soil. When $\mathrm{Mr}$ $\mathrm{M}$ 'Nab first showed it to me I was bound to confess that I had never before seen anything in garden work quite so ugly; it suggested nothing so much as a gigantic counter in a corn exchange for the display of samples. But at the same time I was bound also to confess that it would probably be a great success for the cultivation of plants, especially Alpines; for it gave such plants just what they require, shelter from the extreme heat and glow of the sun, separation from other plants which would choke them, and a moist, cool surface for the roots to run in without fear of stagnant water. The result has shown that $\mathrm{Mr}$ $\mathrm{M} \cdot \mathrm{Nab}$ was right; the plants have done excel- 


\section{In My Vicarage Garden}

lently well, and as they have been allowed to go their own way they have covered up the hard angles and hidden the ugly stones, and so it has been an undoubted success, and excellently suited to a botanic garden, but to no other. I should be sorry to see it much imitated ; the principle of pockets with deeply sunk stones behind which the plants can find shelter from sun and wind can be easily adopted without converting the garden into a gigantic chess-board.

What, then, will make a rockwork which will form a happy home for plants, and be at the same time beautiful in itself and a beautiful adjunct to a garden? I have already said that a rockwork which rises above the level of a flat surface at once proclaims itself to be artificial ; on a sloping ground, especially if very steep, rocks may naturally crop out, and will be useful to keep up the soil, and they are very natural borders to a path at the bottom of sloping ground; and a very little management will give plenty of good places for plants near such rocks. In many gardens there is an old quarry from which the stones were taken for the building of the house; and these always make excellent rock gardens, being below the surrounding garden, with different levels, and generally with a good floor, more or less flat, and sometimes sufficiently moist to form a bog garden. I think it best that a rock garden should not be seen till you are immediately above it or in it; one that obtrudes itself from a distance is in every 


\section{The Rock Garden}

way a mistake, and the best rock garden I have known was a disused slate quarry in a small wood in a very good garden near Plymouth. It was quite invisible till you were actually in it, and then the disintegrated crumbling slate, through which there was a dripping of water, made a very paradise for ferns, and not for ferns only, but for many other good plants that loved shade and moisture. This is the secret of the success of the rock garden at Kew. The surface of Kew Gardens is almost a dead level, but when the time came to make a large rock garden, it was wisely determined not to place on the level a huge mountain of stones, but the happy thought was acted on to imitate the dried-up bed of a stream through a rocky soil, of which the banks would form the rock garden. The exigencies of a public botanical garden forced them to do some things that it would not be well to imitate, e.g. the wide gravel walk in the centre, while the flatness of the surface obliged them to show a flat bed to the stream; if they could have had this on a gentle slope, and if they could also have made some side-paths leading into it, as if they were connected rivulets, the effect would have been better, and they would have had a greater variety of aspects; still it is a decided success, and, having a liberal supply of water, they are able to keep it always fresh, and the plants look thoroughly comfortable.

There is one form of rock garden (if we may so call it) which I think might be often used with 


\section{In My Vicarage Garden}

great effect. I have already written on garden walls, ${ }^{1}$ but I did not mention that in many gardens, especially where the surface is flat, a dwarf wall, built of large stones unmortared, but filled with earth in the interstices, and with earthen tops, will make an excellent home for many good plants, and though it will of course look artificial, it need not look ugly or out of place. The Cornish walls will give a good idea for such walls, and it is the common way of growing plants in the gardens of Portugal, and other parts of South Europe and North Africa. In Mr Crawford's charming book, Through the Calendar in Portugal, after telling us how the Portuguese love flowers, but despise trimness, florists' flowers, or novelty in flowers, and only ask for vigorous growth, rich colour, and sweet scent, he describes the distinguishing feature of the Portuguese garden :-

"A survival of the old Moorish times is the wall running by the garden paths faced with painted tiles. Along the top of the low wall is scooped a deep furrow to be filled with garden mould, and planted mostly with carnations, pinks, and gilliflowers, or the dwarf scented purple iris of Portugal. All these plants like the drought, and so set the flowers can be plucked or smelled to without bending the back-an ingenious device of the ease-loving Oriental."

In the rock garden don't be afraid of shrubs, not only dwarf shrubs, but tall and large ones; nothing will more help to give it a natural ap-

${ }^{1}$ Gloucestershire Garden, p. 203. 


\section{The Rock Garden}

pearance, and to hide what is artificial; and among shrubs I am fond of yuccas for such a place, they naturally grow among rocks, and they look well, whether placed at the extreme top, or in any other part. But avoid all root-work; it looks rather well at first, but it soon becomes a harbour for vermin of all kinds, and as it rots away it very seriously disarranges the whole of the garden, however carefully it may have been put together. Avoid also all such things as fragments of old buildings, old pinnacles, bits of Gothic windows, and, above all, such things as plaster casts, glass balls, glass scoriæ, or any other scoriæ, statuettes, and such like, and if you must have labels (and they are almost unavoidable) have them as inconspicuous as possible; all such things (except the labels) suggest that the whole thing is a sham, and the more natural and wild the rock garden can be made, the better. For this reason I would, if possible, use only one kind of stone, and place the stones, if I could, in their natural positions. All this will involve labour and thought, and doubtless many a good rock garden has been made in a more haphazard manner. I am only giving a counsel of perfection, and much good work may be done without reaching to that.

Nothing is uglier than many rockeries, perhaps the majority of them, but I contend that they are necessities in a good garden, and that they need not be ugly, and may be made quite beautiful; and so I am more inclined to agree-or rather 


\section{In My Vicarage Garden}

I do entirely agree-with Ellwanger in the Garden Story :-

"Of all forms of cultivating flowers, rock-gardening is the most interesting. Within a small space you may grow innumerable dainty plants, which would be swallowed up or would not thrive in the border-delicate Alpines, little creeping vines, cool mosses, rare orchids, and much of the miniature and charming flora of the woods and mountains." 


\section{CHAPTER XI}

YORK AND LANCASTER ROSES

THERE are many roses with variegated petals, but two only rank as York and Lancaster roses. The others I dismiss at once, for though $\mathrm{Mr}$ Rivers speaks favourably of Village Maid or La Villageoise, Eillet Parfait, Perle des Panachées, and Tricolor de Flandres, they have never obtained a footing in English gardens, and from my own experience of them I should not think it likely that they ever will. I shall confine my remarks, therefore, to the two kinds which are best known, and it will be better to begin with the description of them, and then to say something of their history and literary associations.

Of the two kinds one has certainly been known in England more than three hundred years. It is a variety of Rosa Damascena, but its old name was $R$. versicolor. It is an upright rose, often growing six feet high, and in good seasons bearing a large number of semi-double roses, of which some are white, some are pink, and some white and pink combined. The flowers are not large, but it is a very pretty rose, very hardy, and can be increased by cuttings or suckers; it produces a 


\section{In My Vicarage Garden}

few red pear-shaped hips, and I believe, though I have never tried, that it comes true from seed.

It is not a very common rose now, though I fancy it was fairly common in old English gardens, but it has been supplanted by the more showy rose, which I call the second sort of the true York and Lancaster roses. This is a variety of Rosa Gallica, but I have not been able to find any account of its introduction into England, and it is generally said to have been first raised in England, but of this there is no certain proof, but it seems to have been chiefly noticed by English writers. I can find no earlier notice than in Gilbert's Florists' Vade Mecum, I682-an excellent little book. His description seems to imply that neither the rose nor the name were novelties at that time. He describes it thus :-

"Rosa Mundi, the Rose of the World for Scent and form like the common red one, but the colours differ to admiration, were it not by its great increasing grown too common, are in this flower for the most part of a pale flush-colour, diversely spotted, and finely marked with great flakes of the same red as in the common red Rose, making it through the double flower the loveliest thing to eye of its species" (p. 77).

It was well figured by Miller in I 758 as Rosa Pranestina variegata flore pleno; by Miss Lawrence in I796 as Rosa Mundi; and in the Botanical Magazine in 1816 as Rosa Gallica versicolor or $R$. Mundi. All these names are certainly wrong; there can be nothing to connect the York and Lancaster rose with Pliny's roses of Praneste, of 


\section{York and Lancaster Roses}

which he gives no description, but Clusius doubtfully gave the name to the older form, and Miller adopted his name for the later one; Rosa Mundi was also Ray's name for the older form; and Rosa versicolor was also Parkinson's name for the same rose. The name now generally accepted is Rosa Mundi, and as it is so figured in the Botanical Magazine, it is better that that name should be given to the more modern, reserving the name of $R$. versicolor for the older one. By whatever botanical name it may be called, its popular name will always be York and Lancaster, and it well deserves the name, its bold mixture of bright red and pure white making it very conspicuous and attractive. A few years ago it was very scarce, and could only be found in a few old-fashioned gardens, having been pushed aside by the hybrid perpetuals; but now that a love for the oldfashioned flowers has revived, it has been again brought forward, and promises to be as popular as ever. It has an untidy habit, but it is very hardy, and increases freely by suckers, which are apt sometimes to come up a long distance from the parent plant, but it is not easy to strike from cuttings, and I am told that it is very difficult to increase by budding. In some years it produces abundance of hips and seed. I have never sown any, for I have been credibly informed that not more than one in a hundred will come true. Of the history and literary association of this rose I have nothing more to say; but in the history 


\section{In My Vicarage Garden}

of the other there are some very interesting points.

It would be very interesting if we could find out when this rose first appeared in England. There is no certain record of it, but I am inclined to think that it was not seen in English gardens before the latter part of the sixteenth century. Before that time all roses are described as either red or white. Bartholomæus Anglicus, in the fourteenth century, distinctly says that all English roses were so, entirely red or very white (omnino rubra vel omnino albissima); and this is curiously shown by the fact that in all the descriptions of female beauty before that time the pink of the face and lips is always derived from the rose, but the white from the lily, but after that time the variegated rose is naturally used (as by Shakespeare) for the more perfect similitude. The only poet or writer, as far as I know, that mentions the red and white rose earlier than Shakespeare is the Scotch poet, Dunbar, who wrote at the end of the fifteenth and beginning of the sixteenth century, and he says :-

Nor hold none other flower in sic dainty As the fresh rose of color red and white.

Dunbar was a traveller, and may have seen the rose in foreign countries, but I think it doubtful, and think the "rose of color red and white" may mean red and white roses, and not red and white in one rose. But towards the end of the century 


\section{York and Lancaster Roses}

the rose must have been well known and popular. Shakespeare decides this, for he certainly mentions the rose three if not four times:-

For flesh and blood, sir, white and red, you shall see a rose; and she were a rose indeed.

Pericles, Act iv. sc. 6.

The roses fearfully in thorns did stand, One blushing shame, another white despair ; A third, nor red nor white, had stol'n of both, And to his robbery had annexed thy breath.

Sonnet xcix.

I have seen roses damasked, red and white, But no such roses see I in her cheeks.

Sonnet cxxx.

More white and red than dove and roses are.

Venus and Adonis, iv.

Pericles was probably only written in part by Shakespeare, but whether by him or a contemporary it matters little to my present purposei.e. to fix a date for the introduction of the rose. The sonnets were published in I609, but probably written at least ten years earlier. ${ }^{1}$

I may now go to the botanists. The first description of the rose is by Clusius, in I60I. I omit his botanical description that I may find place for Parkinson's, but he tells us that he first

1 To these passages may perhaps be added the whole scene in the Temple Garden, I Henry VI., Act ii. sc. 4. The text will quite bear the interpretation that the different white and red roses were all plucked from the same "thorn" or "briar." 


\section{In My Vicarage Garden}

heard of it from John Restan, of Cologne, in I600, and had a plant from him, but it had not flowered. He gave it, however, the name of $R$. versicolor, which it has since retained. Gerard does not mention it at all in I597, nor is it mentioned by Johnson, the editor of the second edition in 1633 , so it is probable it was not much known in England then. But in 1656 Parkinson described it, and his description is so good that I am tempted to quote the greater part of it :-

The flower (being of the same largenesse and doublenesse as the damaske rose) hath the one half of it sometimes of a pale whitish colour, and the other half of a paler damaske colour than the ordinary; this happeneth so many times, and sometimes also the flower hath divers stripes and markes in it, as one leaf white, or striped with white, and the other half blush or striped with blush, and sometimes all striped or spotted over, and other times little or no stripes or marks at all, as nature liketh to play with varieties in this as in other flowers.

But if I am puzzled to say when the flower first came into English gardens, it is still more difficult to say when it first got its excellent name of York and Lancaster Rose. Hoffman, in his excellent Lexicon, I698, after describing the Wars of the Roses, says that on the union of the two houses a double red and white rose formed part of the English Royal insignia, but he gives no authority for the statement, and I do not remember to have seen it elsewhere; but if it was so it would be natural to call the new rose after the existing insignia, and it would be 96 


\section{York and Lancaster Roses}

a natural and obvious compliment for the courtiers of the time of Henry VIII. and Elizabeth to say how Nature had shown the excellence of the union of the houses of York and Lancaster by joining in one fair flower the white rose of the one to the red rose of the other. But the first notice I can find is in the heading to Parkinson's description, just quoted, "Rosa Versicolor: The Party-coloured Rose, of some York and Lancaster." This shows that the name was a common name in Parkinson's time, and was not invented by him. About the same time Cleveland, the poet, wrote :-

\section{Her cheeks}

Where roses mix ; no civil war

Between her York and Lancaster.

I can get no nearer to the origin of the name than this. It was probably a chance name happily chosen, which at once took the public fancy, and so has remained with us. I will finish my paper with an epigram which is well known, but is clever enough to bear repetition :-

If this pale rose offend your sight

Laid in thy bosom bare ;

'Twill blush to find itself less white,

And turn Lancastrian there.

But if thy ruby lip it spy,

And kiss it thou may'st deign,

With envy pale 'twill lose its dye,

And Yorkist turn again. 


\section{CHAPTER XII}

\section{PLANT NAMES}

Plants must have names, and most of the names which are now so fixed have gone through many changes, and I do not intend to tell how they have changed and how they have become finally fixed. That has been done by many writers on botany, and can be well studied in a small compass in Professor Earle's excellent little book on English Plant Names, in the Introduction to which he gives the account of the progress of plant-naming from Theophrastus to Linnæus and Jussieu. What I rather wish to do is to show that however unattractive at first sight the study of plant names (I mean their scientific, botanical names) may be, there is in them a fund of instruction and interest which will well repay the labour spent upon them. That there must be such names, joined or not with popular English names, is an absolute necessity in botany, as in every other science ; for "the first necessity for science," says Professor Earle, "was to know the objects, and to know them by their names." In botany these names are certainly very often long and cumbrous, uncouth and unclassical, and to many 


\section{Plant Names}

who use them they can convey no meaning at all, and I have often listened with wonder to men and women with no classical education whatever, and without the slightest knowledge of Greek or Latin, using a multitude of these long words (sesquipedalia verba), and using them accurately and, in many cases, with a real knowledge of their meaning, though with no knowledge of their derivation; in such cases, their use of these words shows a wonderful power of memory, which is no way helped by tracing the fitness of the name for the plant.

There is now, and there always has been, a desire to use for plants popular names only, and the long scientific names have been mercilessly held up to ridicule, and have given occasion for many harmless jokes. Yet it is not easy to see why botany should have been so specially singled out for abuse and ridicule of its scientific names, except that perhaps the study of gardening and botany is the most popular of the sciences, and is followed up by a larger number of half-educated people. Rocks and stones, butterflies and moths, and especially birds, are as much common objects of the country as trees and flowers, and the different sciences of geology, entomology, and ornithology make use of scientific words not only as difficult to understand as the scientific names of plants, but much more difficult, because there is not the same connection between the names and the objects that there is in botany; and yet 


\section{In My Vicarage Garden}

in these sciences the names are not laughed at, nor any attempts made to do without them in common use. Take the case of entomology, and especially that part of it which deals with butterflies and moths, probably the most popular partcertainly the part that is first taken up by young people. Many of these have popular English names, and some of them are fairly descriptive of the insects, but the collector is soon taught to ignore them, and to keep steadily to the scientific names; and when he does so he must be often puzzled to find any reason for the names given, or to trace any connection between the name and the thing. I take up the Accentuated List of the British Lepidoptera, and in the first page I find the following names of butterflies:-Pieris, a muse; Daphlidoce, one of the daughters of Danaus; Colias, a surname of Venus; Edusa, a Roman divinity; Hyale, a nymph in the train of Diana; Argyunis, a surname of Venus, etc. Such names can give the student no information about the nature of the butterflies so named, or induce him to try and find out from the names something of the history of the insects. In botany the case is quite different. I believe it would be hard to find among plants a single plant name that had not a meaning; in every plant name, not only the specific, but the generic name as well, there is something that tells of the history of the plant, either its discoverer, or its native place, or its structure, or its appearance as distinguished from 


\section{Plant Names}

its near relatives. And it is this history which, as I contend, lifts the most forbidding-looking botanical names from their apparent uselessness and dryness, and gives them an interest which adds largely to the other interests of the garden.

I can illustrate what I mean by a few examples, taken partly from the native plants, and partly from exotics. The greater number of the names of our native plants have been adopted from the oldest writers. In some cases, no doubt, they have been given to very different plants than those of the old writers, but always with good reasons; but it would be too long a task to enter into this part of the subject. What I want to show is how every name draws our attention to some peculiarity in the particular plant which distinguishes it from all others. Take our meadow cranesbills, very common in many parts of England, and of a rich blue colour that is not surpassed by any. There are three families closely allied-the geranium and the erodium of our own country, and the pelargonium chiefly of the Cape, and entirely so but for one curious outlier in Asia Minor ( $P$. Endlicherianum) and two in New Zealand. The three names are all pure Greek- $\gamma^{\prime}$ fpavos the crane, spworo's the heron, and $\pi \varepsilon \lambda \alpha \rho \gamma^{\prime} s$ the stork, and they all three at once draw our attention to the long sharp-pointed seed-vessels so closely resembling the long, sharp bills of the crane, the heron, and the stork. Having got so far, the specific names point out to us how one differs from another: 


\section{In My Vicarage Garden}

that one is phoeum, or dark-flowered, while another is sanguineum with red flowers; one is sylvaticum, of the woods, another pratense of the meadows, a third maritimum of the seashore, and a fourth Pyrenaeum, having its headquarters in the Pyrenees, while the structure is shown in one, being Nodosum, with knotty joints, and another Rotundifolium with round leaves, and so on. This will show what I mean from our native plants; in exotic plants the scientific names often tell us a great deal of the geography or discovery of the plant, and so often give valuable help to the cultivator. If he gets a plant having for its specific name Javanicun, Brasiliensis, Benghalensis, Madagascarensis, Aethiopica, etc., he knows at once that it is a tropical plant, which can only be grown in a hothouse; if it is labelled Chilensis, Chiloensis, Magellanica, Mexicana, Capensis, or Novae Zealandiae, he knows at once that it is probably half hardy, and may be worth trying as a hardy plant; if the specific name is Japonica, Siberica, Tartarica, Canadensis, borealis, or Arctica, he has little scruple in trusting it out-of-doors, being well assured of its hardness, though for some mysterious reason it may defy cultivation in England; if the name is Himalaica, Atlantica, Caucasica, Alpina, or montana, he knows at once that it comes from a high elevation, and must be treated accordingly to the best of his powers; while on the other hand he will reject a plant which reveals its low level nature by the names paludosus, lacustris, aquatica, 


\section{Plant Names}

or hydrophilon, unless he can give it a pond or a bog. He will get the same help when a plant bears the name of its discoverers if he has any knowledge of the travellers; a plant named Douglassii is sure to come from California, Wallichei from the Himalayas, Sieboldi or Fortuni from Japan or China. In these different ways I contend that a knowledge of the scientific names will tell much that is useful to know, and so will add largely to the interest and pleasure of the garden.

Nor is this all. Many of the scientific names, especially the older names, contain much of history and folk-lore. A large number still preserve their old medical names, which pointed out to the student for what complaint he was to use them, though they may no longer be so used now. The paronychia was a cure for the whitlow, and Herniaria for ruptures; aegopodium podagraria would be administered for the gout, and Campanula trachelium for a sore throat. Old folk-lore is preserved in a large number of names, but two or three will suffice. Morsus diaboli preserves the old legend that to destroy the wonderful effects of the plant the Evil One bit off the root; Carduus benedictus claims by its name to have received a special blessing which gave it the virtues of a heal-all; while the passiflora, or flos passionis, recalls the story of the old missionary's joy in finding in heathen lands a beautiful flower in which he could discover all the emblems of the 


\section{In My Vicarage Garden}

Passion. One extreme instance will show that even in our own times a name may be given which in time to come will perpetuate the history of a savage custom now happily passed away. In the Fiji Islands there grows a solanum (very like our tomato) which has obtained the ghastly name of solanum anthropophagum. As long as the name lasts it will tell the story that the Fijians were once cannibals, and grew this vegetable specially for their cannibal feasts, human flesh being, according to the reports of Dr Leeman and Professor Moseley, very unwholesome unless eaten with certain vegetables, grown for the purpose, of which the solanum was in most request. The Fijians are no longer cannibals, but that they were so once will always be told by this plant.

I would then recommend to all lovers of a garden to learn all they can of the scientific names of their favourites, just as I would recommend them to learn all they can of their structure, their botanical affinities, and their geography, for the simple reason that the more they learn the more they will wish to learn, and the more they will find to study with loving admiration. But it does not follow from this that I think lightly of the common English names of our plants. Our old English names are full of a special charm, and I have always delighted not only to trace them through our literature, but to preserve them in every possible way, and to use them in preference to any others. They will make for any 


\section{Plant Names}

one a separate study by themselves, and a very delightful study, and the many books which have been written about them show what a fascination they have had even for great scholars. I doubt if there is anything in our English country life, or in our English home life, which has come down to us so unchanged as our common plant names. Professor Earle, in his English Plant Names, extracted all the names given in the glossaries from the tenth to the fifteenth century. Since that the Epinal Glossary, supposed to be of the beginning of the eighth century, has been published. In this glossary there are I 23 names of plants, of which a few have no English translation; but there are more than ninety in which the old English names are exactly the same as the names of the present day; so that we may say that for more than I 200 years the names have remained unchanged. During the last few years attempts have been made largely to increase the number of English names for exotic plants, and even to insist that none but English names should be used by English botanists. I have no wish to enter into the discussion of this vexed question; I will only say that I think the attempt is both unwise and mischievous, and if adopted by other nations would lead to a woeful confusion, and, instead of knowing our plants by the one accepted scientific name which would be good in every civilised nation, we should have to learn the different names adopted in each separate country. 


\section{In My Vicarage Garden}

Baron von Mueller, the energetic Government botanist for Victoria, in his account of tropical plants useful in manufactures, etc., has given good reasons against this. In writing the book he says that -

"Vernaculars have been but sparingly used, being so often of duplicity or even multiplicity in their application, and so frequently also misleading. We should strive to simplify nomenclature, and should reduce popular names to such solitary and logical expressions as most readily can be understood in each instance. Thus it is as easy to say Casuarinas as the very objectionable appellations Sheoak and Heoak."

I know that there are some, but not many, I should think, who profess to love flowers, but who say they care nothing for the names, whether English, Latin, or Greek. They will quote from Shakespeare that "a rose by any other name would smell as sweet," or Tennyson's description of the baronet's garden, in which-

"Flowers of all hue and lovelier than their names Grew side by side."

With such I have no sympathy; it is a real pleasure to me, and I know it is to many others who are not only botanists, but good garden masters, to hunt up the history of a plant name; to trace it from Theophrastus, Dioscorides, and Pliny till I get the helping hand of Gaspar Banhin, who in the seventeenth century summarised for me in his great Pinex Theatri Botanici all the names that had gone before; and then Miller, in his Gardener's Dictionary, will do much I 06 


\section{Plant Names}

to fill up the gap between Gaspar Banhin and the nineteenth century. I should, indeed, like to go back further than Theophrastus, for plants must always have had names, and I should like to know where they are first mentioned. ${ }^{1}$ I suppose the earliest names in the Bible would be those in the Book of Job, and I have been told that very old Egyptian names have been discovered, but I am very ignorant of Egyptian literature. The earliest distinct mention that I have found of the use of plant names in a garden is in the Odyssey. When Ulysses is making himself known to Laertes, who in his doubts asks for some sign, he very simply tells him that he will show him in his garden the trees that he gave him as a boy, and at the same time taught him their names:-

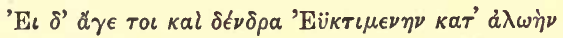

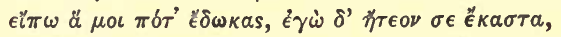

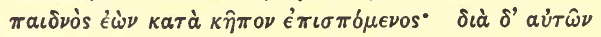

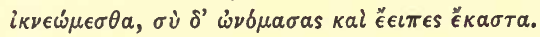
-xxiv., $335-33^{8}$.

"I'll tell you, too, the trees (in goodly frame Of this fair orchard) that I askt of you Being yet a child, and followed, for your show And name of every tree."-Chapman's Translation.

1 We are told that "Adam gave names to all cattle and to the fowl of the air and to every beast of the field"; but according to Milton the naming of the flowers of Eden fell to Eve ;

$$
\text { " O flowers, }
$$

Which I bred up with tender hand

From the first opening bud, and gave ye names."

-Paradise Lost, xi. 277. 


\section{CHAPTER XIII}

\section{THE SCENTS OF FLOWERS}

THERE can be no doubt that the whole subject of flower scents is a very interesting one, and that no botanical student can altogether leave it out of his studies. The subject, so far as it concerns the perfumer only, was well treated of by M. Eugene Rimmel, in his Le Livre des Parfumes, published in I 870, with an introduction by Alphonse Karr, and an enlargement of The Book of Perfumes, published in I 860 ; and the same subject from the same point of view has been thoroughly worked out by Mr J. C. Sawer in his Odorographia, I 892 , I 894, and his Rhodologia, I 894. But there is a great deal more strictly botanical connected with flower scents on which there is much to be said, and a great deal also which we can only call unsolved mystery.

The scientific and botanical interest range round the question, "What is the use of scent in plants?" It is not many years since this question would have been answered at once, and without the slightest hesitation. The answer would have been that owing to their delicate scent plants became more pleasant food to all the animals that feed I 08 


\section{The Scents of Flowers}

upon them, and still more, that the scents were a delight to man, and for that purpose especially they were created. To think otherwise would have been considered heresy and unbelief; by a distortion of the text which gave to man "Every green herb of the field for meat," it was argued that the ultimate object of every part of every green herb of the field was to fit it for the food or for the delight of man. We now think differently, and give our answer as boldly. While we thankfully acknowledge that the beauty of flowers, their scents and flavour add largely to our enjoyment of them, we say now without hesitation that it is not for us especially that the beauty, scents, and flavours of flowers have been produced. Our present creed is that every colour and every shade of colour in a flower, every arrangement of cell, root, fibre, stamens, pistils, calyx, corolla, etc., all and each have the one object of perfecting the life of the plant, and helping it to reproduce itself. And if this is true of other parts of the plant it must be true of the scents. In some way or other the scents must be an essential part of the life of the plant; they must perform some special duty which nothing else could perform. And in speaking of the scents of plants and their function in the life of the plant, it will not do to confine our research to sweet scents ; for it is quite certain that evil scents-evil, that is, to us-are as essentially necessary to the plants in which they are found as rich, pleasant scents are to other flowers. 


\section{In My Vicarage Garden}

Speaking generally it is now assumed, and by many is supposed to be proved, that scents, especially sweet scents, attract moths and other insects whose help is necessary to the perfecting of the plant, while evil scents help-like thorns, prickles, and stings-to keep away animals, especially browsing animals, from plants which would thus be destroyed. This may explain some small portion of the uses of scents to the plants, but it is far from explaining all; it gives no explanation, for instance, of those cases where the scent is only found in the roots, or in the seed, nor of the cases where the scent is very strong in the leaves, and where the flower does not require insect agency as in the lemon-scented verbena; nor of the hundreds of cases of exotic plants grown in England, where the scent is very powerful, but the plants never produce seed. And though this explanation is often spoken of as one of the discoveries of modern science, it is not so; it is at least as old as Lucretius; though his explanation refers more to the food of the animals than of the plants :

"Aliis alius nidor datus ad sua quemque

Pabula ducit, et a tetro resilire veneno

Cogit ; eoque modo servantur secla ferarum."

De Rer. Nat. iv. 687.

Lucretius was so fond of giving examples of natural objects that supported his theories that it is a pity he did not give us examples from his own observations of plants whose scents either 


\section{The Scents of Flowers}

attracted or warned off different animals, but he did not do so. There is no difficulty in finding hundreds of examples, and the common buttercup is as good an instance as any of the way in which animals are warned from dangerous plants by this very acute sense of smell. To us the scent of a buttercup is almost imperceptible, but to the cow the scent is sufficiently strong to protect the plant from being eaten. It is most curious to examine a field full of buttercups in which cows are grazing. In some years the field seems to be nothing but buttercups, a veritable cloth of gold, yet the cows go through it, eating all the grasses but leaving both the leaves and flowers of the buttercup untouched. In this way the life of the buttercup is preserved, and as far as we can see it owes its preservation entirely to its scent. The colour would not deter the cows, for they eat many yellow flowers, nor would the acrid taste or shape of the leaves deter them, for from the relative position of the eyes and mouth of the cow when feeding it is certain that they cannot see the actual plant they are feeding on, and so it can only be by the scent that they are warned from it. And if animals are deterred from some plants by their scent, it is by the scent that they are attracted to others. It is not known for certain how night moths are attracted to flowers whether it is by sight or smell, but it seems most probable that they are attracted in some cases by sight and in some by smell, and in some by both 


\section{In My Vicarage Garden}

combined. It may be that they are attracted first by sight, for it has been often noted that a large proportion of the flowers visited by night moths are white, but when so attracted it would seem that their sense of smell tells them whether the flower is good for them, and indeed whether it is the very flower they are seeking for. For all insects seem to have their own special flowers, and all flowers their own special insects. There are, of course, cases of flowers being attractive to more than one family of insects, and there are insects, such as bees, which do not confine themselves to one flower only; but they all work within certain fixed limits, and there are cases when, if the particular insect does not come, the flower cannot perfect itself. The common red clover is a well-known case in point, which so much requires the help of humble-bees-and no other bee can help it-that Darwin believed that if humble-bees became extinct in England the red clover would wholly disappear; and in New Zealand it was necessary to ship a large quantity of humble-bees from England before the red clover produced any seed. A less known and almost more curious instance occurs in the yucca, which in Texas is fertilised by the small moth pronuba yuccassella. In England the yucca at night is much more attractive than by day; the flowers, which are bell-shaped by day, open and become bright stars by night, and the delicate scent is more perceptible; but all the attractions are in vain, the pronuba is not 


\section{The Scents of Flowers}

in England, and though seed vessels are formed, perfect seed is never produced here, for apparently no British moth can or will do the required work.

A large volume might be written, and more than one has been written, on the different attractions which different plants offer to the insects which are necessary to them, and among these attractions scent holds a chief place. But this does not prove, and as far as I know it has not yet been proved, that scents are formed in flowers to attract or ward off insects and other animals, and, to my mind, the explanation goes a very small way to account for the existence of scents, which, as I have already said, seem to me to be so far essential parts of the plant that in some way, which I cannot in the least explain, the plant is imperfect without its own peculiar scent, so imperfect that the life of the plant cannot be completely carried on if the scent or the glands containing the scent are absent. Yet I do not suppose from this that scent can ever form a scientific differentia between one genus and another, or between one species and another, for we must allow that nothing can form such a differentia which is impalpable to the touch or invisible. Lucretius, indeed, held that odours, though invisible, had bodily substance, and in his desire to explain everything in nature he proved his point by the assertion that odours strike the nostrils :-

"Omnia corporea constare necesse est Natura, quoniam sensus impellere possunt ;" 


\section{In My Vicarage Garden}

but modern science does not admit this, and Linnæus pointed out how erroneous it is to attempt to separate species by their odours from the familiar example that a dog will pick out his own master in a crowd of other men, not by sight but by smell, and so his canon was, "Odor speciem nunquam clare distinguit." Yet, in his love of classification, he classified the scents of flowers, and divided them into six classes-(I) Ambrosiaca, such as musk, sweet-scented geranium, etc.; (2) Fragrantia, such as the flowers of pinks, jasmine, violets, etc., and the leaves of lavender, thyme, balm, etc. ; (3) Aromatica (similar in taste and smell), such as cinnamon, camphor, orange, etc.; (4) Graveolentia, subdivided into Alliacea, such as onions, garlick, asafœtida, etc., and Hircina, such as herb Robert and others; (5) Tetra, such as hemp and elder; and (6) Nauseosa, producing sickness, such as veratrum, colocynth, and tobacco (!) This is a curious arrangement of flower-scents, and it is open to the objection that the same scents are very different to different people, so that scents which would range themselves to some under tetra or nauseosa would be ranged by others under fragrantia or aromatica.

There are many curiosities connected with the scent of flowers, but there is none more remarkable than the way in which different persons are affected by them. In some the sense is entirely wanting, as in Dean Stanley, but in others who 


\section{The Scents of Flowers}

have a keen sense of smell the scent of flowers does not seem the same in any two persons. I have heard, indeed, of a school inspector who tested, or tried to test, the capacities of some unfortunate school-children by telling them to describe not only the colours, but the scents of certain flowers; but the ways of school inspectors are wonderful. And it has been gravely asserted that none but those with a long pedigree can detect the smell of strawberry leaves dying in the autumn, though Bacon classed their "most excellent cordial smell," with violets and roses-i.e. with the most common flower scents. If we may judge from his silence, Homer seems to have known nothing of the scents of flowers, for he never mentioned them ; and, indeed, they are not much mentioned by any Greek or Roman writer, though both Greeks and Romans extracted the scent for perfumes and ointments. The Bible, as might be expected from its Oriental connection, has frequent references to sweet smells, especially of fruits and flowers, from Jacob's "smell of a field which the Lord hath blessed," to St Paul's " odour of a sweet smell" and "sweet-smelling savour," to which he compares acceptable works. And English writers of all ages have rejoiced in the scents of gardens and flowers; Shakespeare is full of his enjoyment in "the garden of sweet flowers, that dainty odours from them threw around," and Milton's appreciation, which was probably increased by his blindness, is shown in a very 


\section{In My Vicarage Garden}

curious way. He had a deep love for the ipsissima verba of the Bible, and in most cases keeps as close as possible to them. But in his description of the Fall, he goes beyond the text, which tells how "the tree was good for food, and that it was pleasant to the eyes," and he makes the chief temptation to lie in the scent. Satan first says that-

"From the boughes a savorie odour blown, Grateful to appetite, more pleas'd my sense Than smell of sweetest fennel."

Then in Eve there "waked an eager appetite, raised by the smell so savorie of that fruit"; and then she brought to Adam-

"A bough of fairest fruit that downie smil'd, New gathered and ambrosial smell diffused."

And, I believe, Milton is the first writer that called the fruit an apple- " that crude apple that diverted Eve"-though he may have used the word in its old generic sense, by which almost any fruit was called an apple.

Another curious thing in scents is that while some flowers give out their scents voluntarily, in others it has to be searched for. Of course, this is so with plants whose scent is in the root or seeds only; but it is also the case with numberless other sweet-scented flowers; they have the scent, but they keep it to themselves. Among flowers which are "fast flowers of their smells" Bacon reckons roses, bays, rosemary, and mar- 


\section{The Scents of Flowers}

joram. Among flowers that are not so fast in their smells the chief are limes and violets. In a wood you may smell violets before you see them, and rejoice in them; you may also in the same way detect the presence of ransoms or wild garlic, but without the same enjoyment. I believe that nearly all night-scented flowers give out their scents voluntarily; it is so certainly with the night-scented stock, the night-blowing cereus, the lychnis, and many others, and this would be very useful in attracting the moths. It is well known how strong is the scent of the sweetbriar after rain ; this is supposed to arise from the breaking of the scent-glands by the rain, which is also the explanation of the strong scent of mint, thyme, and other low-growing herbs when trodden on. How large a part in the structure of some plants is filled by these scent-glands may easily be seen by holding up a myrtle leaf to the light ; the transparent dots are the glands containing the scent.

Another curious thing in flower scents is that, however strong the scent of some plants is, it is quite imperceptible to some persons, who yet have the full gift of smell. I knew a gardener who was very sensitive to evil smells, but he told me he could detect no scent whatever in any flower, except the lemon-scented verbena (the leaves of course) and some tea roses, but he was a great snuff-taker, and he fancied that had altered, but not destroyed, the sense of smell.

The commercial value of flower scents is very 


\section{In My Vicarage Garden}

noteworthy. The manufacture of otto of roses, which was brought to Europe from Persia, was confined till very recent years to certain valleys in Bulgaria, where it was carried on in a very rude but picturesque fashion; it is now carried on more scientifically and with large profits in the south of France and in some parts of Germany. And it is the scent alone that gives a commercial value to some other plants. The orchid family is, with the exception of the compositae and gramineae, the largest botanical family, as it is one of the most beautiful. Perhaps, too, more money has been spent on orchids than on any other tribe of plants, yet its strictly commercial products are confined to the sweet-scented seed-pods of the vanilla, for the small production of starch and salep from a few other species is scarcely worth mentioning. In the same way in the "poor man's orchid," or Iris, the only commercial product is derived from the violet-scented orris root, which is made from Iris Florentina.

Flower scents, like everything else, are amenable to education; but they have this peculiarity, that I know of no instance in which education, if we may so call the high cultivation of some plants, has increased or improved the scent; but there are many cases in which it has been quite destroyed. We now have scentless roses, which seems almost a contradiction in terms, and scentless carnations; but I believe that if these were to be so neglected as to degenerate, they would 


\section{The Scents of Flowers}

gradually recover not only their old shapes, but their old scents ; but on this I must speak doubtfully. I suppose this destruction of scents is analogous to the destruction of the poisonous qualities of plants by cultivation, as in the wellknown cases of the carrot, parsnip, and celery; and I suppose it is also analogous to the way in which the unpleasant properties of plants are dispelled by cooking.

And among the most curious and the most delightful properties of flower scents is the way in which, more than anything else, they help to recall days that are past, and places and friends that are far distant. "I can shut my eyes and think about gardens and that," said a child in a children's hospital, when a bunch of wallflowers was given to her. But on this part of my subject, pleasant though it is, I must here say nothing, because I have already said much in a former paper on "Garden Associations," 1 and because I must bring my paper to a close. I will do so by expressing a hope that from the little here said some will regard flower scents not merely as an adjunct of flowers formed to please the nose, as the shapes and colours please the eye, but as something which the life of the plant requires. That we cannot tell everything about them is of very small consequence; they add to the delight of our gardens, and, none the less so, because they are mysteries.

1 "In a Gloucestershire Garden," p. 269. 


\section{CHAPTER XIV}

THE MEDICAL PROPERTIES OF FLOWERS

By "their medical properties" I mean that every plant has either in its juices, or in some other definite part, certain qualities which not only determine its taste, but which also make the plant wholesome or unwholesome to man or beast ; and I consider that these qualities, though not sufficient to create a scientific differentia either in a genus or species, are yet so distinct in each plant that they are essential in some way or other to the life and well-being of the particular plant in which they are found.

In the medical properties of plants there are two extremes; in the one extreme every part of the plant is a deadly poison to man and beast; in the other, as in the date palm, and the bamboos, there is no part of the plant that is not useful to man, and is conducive to his health and comfort. The existence of the very poisonous plants is a great puzzle to those who can only estimate the value of a plant by its usefulness to man; for a plant which in its normal and natural state is fatal to man can hardly be considered useful to him, however it may be modified by dilution or otherwise 


\section{Medical Properties of Flowers}

into a medicine. But when it is recognised that in some way or other what we call the medical properties of a plant are essential to its life and well-being, then a good reason for its presence in the plant is established.

But though I feel sure that the medical properties of plants are necessary and essential parts of them, yet they cannot form a scientific differentia either in a genus or species. As with scent, so with the medical or other uses of a plant, Linnæus condemned their being named to distinguish genera or species, though he allowed the medical names to be used as synonymous ; but his rule was, "Vis et usus differentiam Botanico vanam subministrant", and he even said that genera established pharmacopeorum gratia were contra leges creatoris. The medical properties of plants may, therefore, take the rank in scientific botany that the scents do; but there is one very important difference, and it is on that that I wish especially to speak in this paper; and the difference is this, that in a very large number of plants the good or bad qualities of a plant can be distinguished by the growth, shape, colour, etc., of the stems, leaves, or flowers ; so that even without a deep knowledge of botany, almost any observer can say of a plant that it is good for human use or bad.

This is a very old opinion, and it reached its height in the sixteenth and seventeenth centuries. The old doctrine was, Millia sunt mala, millia etiam remedia, and it was a matter almost of 


\section{In My Vicarage Garden}

religious faith that though man was subject to endless diseases, there was for every disease a certain remedy; and more than that, it was believed that the Creator, in His pity for suffering man, had so marked different plants that every sufferer could easily discover for himself the plant that would meet his special need. This was the doctrine of signatures, of which a great deal was written that was both silly and false, but which was firmly held not only by those who were themselves silly or false, but also by many who were really good and learned men. According to this doctrine you had only to look at a plant, and if you could find anything that in shape or colour resembled the part of the body that was diseased or the disease itself, that was at once a proof that the plant was good for you; it was nature's own prescription, which could be safely followed; for in every plant there was good or evil or both; they were all "baleful weeds or precious-juiced flowers," and by their signatures each could be placed in its proper rank. Without going into this at any length it will be enough to say that a heart-shaped leaf was supposed to be good for heart disease, a spotted leaf (like pulmonaria) was good for diseased lungs, a plant with swellings at the joints was good for gout, while the extremes were reached in the walnut and the fern: the walnut, with its outer skin, its hard, brittle shell, and its peculiar kernel was a sure remedy for all diseases of the head, whether of the skin, the skull, 


\section{Medical Properties of Flowers}

or the brain, and the fern, from its absence of flowers and apparent want of seed, was the chief or only ingredient in making invisible garments.

We now laugh at the doctrine of signatures; and in this, as in many other matters, we flatter ourselves that we are better and wiser than our fathers. But with them it was no laughing matter; it was held in all sober seriousness, and was freely quoted as a striking proof of the love and goodness of the Creator. And now it is found that though they were wrong in the working out of the principle, yet that the principle itself is not altogether wrong, for the modern botanical arrangement of plants, the natural system, has clearly established the fact that a knowledge of the structure of plants, and even a very limited knowledge, will go a long way in determining whether a plant is wholesome or baleful. This was not the intention of those who worked out the system, nor is it an essential part of it; but it has arisen naturally, and the result has been that certain families of plants, and those among the largest, carry in their outward structure distinct marks of their medical values and other useful or hurtful properties. A very short glance at some of the principal botanical families will show what I mean.

The first great family with which an English botanical student has to make himself acquainted is the large family of the Ranunculaceae. The family is very easily distinguished by the many 


\section{In My Vicarage Garden}

stamens surrounding but lying under the ovaries or ovary, and it is a large family containing more than 500 species, and is remarkable for the abundance of plants produced in almost every one of the species, and every genus and every species of the family is more or less poisonous to man ; every individual in the family bears upon it a sure signature that it is not good for food; and that every preparation made from it must be used with caution.

Another family is as clearly marked and as easily recognised - the great family of the Cruciferae, with its four petals always arranged in the form of a cross and no bracts, has over I 200 species, and it contains many of the plants most useful for human food - the turnip, radish, cabbage, cress, seakale, mustard, and many others, all belong to this family; and we are not surprised to find that the old herbalists easily recognised this peculiar character, and that the old emblem-writers seized upon it to enforce the lesson of "in cruce salus."

Another large and important family, equally well-marked for good, and as easy to distinguish, is the family of the Labiates-always with square stems, opposite leaves, and irregular flowers. No family is more easily recognised, and as a further help the aromatic scent of the plants will give a sure sign, for throughout the whole family, numbering 2600 species, I believe there is not one species without this fine aromatic scent either 


\section{Medical Properties of Flowers}

in stem, leaves, flower, or seed, and sometimes in all, and not one species which can in any way be called hurtful to man or beast. It is in this family that we find mint, thyme, lavender, marjoram, peppermint, basil, sage, balm, and a host of other similar plants, many of them also among our most beautiful garden flowers.

I have taken three families in which the harmful and wholesome properties are distinctly marked; I will shortly take one in which they are combined and yet are curiously separate, and are also distinctly marked. There is no need to dwell on the distinctive marks of the rosaceae ; they (almost universally) have regular flowers of five petals, the leaves with stipules, many stamens, and in the great families of the roses (roseae), the apples (pomeae), and the plums (pruneae), of which only I will speak, with the seed-vessel, or fruit beneath the calyx (ovary inferior). To this large family we are indebted for our best and most wholesome fruits - pears, apples, strawberries, peaches, apricots, nectarines, plums, raspberries, blackberries, cherries all belong to this family; and there is nothing unwholesome to man or beast, with some curious and well-marked exceptions. Where the fruit is a fleshy pome, as in apples or pears, or in many combined drupes, as in raspberries and blackberries, the plant is altogether wholesome and good. But when, as in another branch of the family, the pruneae, the fruit is in single drupes, with the seed or kernel 


\section{In My Vicarage Garden}

enclosed in a hard shell, as in plums and cherries, the fleshy part of the fruit is wholesome and refreshing, but in the kernel and in the leaves there is a large quantity of prussic or hydrocyanic acid. This mixture of wholesomeness and unwholesomeness in the same plant was a great puzzle to the old herbalists; but they could not resist the fact, and Friar Laurence, in his pleasant moralising on the virtues of plants, did not pass this by:-

"Within the infant rind of this small flower

Poison has residence and medicine power;

For this, being smelt, with that part cheers each part ;

Being tasted, slays all senses with the heart."

And then he pleasantly traces the analogy of good and evil in us, "in man as well as herbs, grace and rude will."

Space forbids my going much further into this question, but I must name, though very shortly, two more families, which I can scarcely pass by altogether, for they stand out from all other botanical families by the large number of the species they contain, and by the strong characters which so easily distinguish them from all other plants. The two families I mean are the compositae and gramineae. The merest tyro in botany knows the general appearance of a composite plant, of which the daisy, the dandelion, and the groundsel are such familiar instances; but the most learned botanist will confess that the family is full of puzzles and difficulties, which 


\section{Medical Properties of Flowers}

few would boast to have altogether mastered, for the family consists of more than 1000 genera and 8000 species, of which the groundsels alone claim over 500 species, and they are scattered all over the world. Yet of these 8000 species there is not one that can be called absolutely hurtful; it is true there are not many that are of much use to man, but it is something to know that at least they will not hurt him. The other great family, the gramineae, do not contain so many species - they are between 4000 and 5000-but in abundance of individuals they surpass all other plants. They are to be found everywhere, in all climates, arctic, tropical, or temperate; they are in every geological formation; they are easily distinguished from every other plant, and there is not a single member of the family from the minutest grass to the most gigantic bamboo, that is not useful to man. Sir J. Hooker well sums up the properties of the family - "Nutritious herbage, and farinaceous seed; stem and leaves useful for various textile and other purposes."

I have only mentioned six families of plants, but they are good representative families, and I have selected them because they are easy of recognition; but I could easily have gone much further and have shown that what I have said of these six families is, more or less, true of all plants; and the point that I wish to establish is that our fathers were not so foolish as they might appear in their doctrine of signatures; there is 


\section{In My Vicarage Garden}

such a doctrine, different from theirs, but perfectly true; and that it is true is, I think, a very remarkable fact, because the present arrangement of plants was carried out with no reference whatever to the medical or economic uses of plants; yet these uses do so range themselves under different families that a knowledge of the structure of the plants in any family is a great help in arriving at a knowledge of the uses. In some cases the qualities of a plant are shown not by the stem, leaves, or flower, but by the juices; as in the Euphorbias and Asclepiads, where the white, clammy juices at once give a warning that the plant is to be suspected. And there is one curious case in which a very small difference in the form of the leaf is enough to show its qualities. Senna is produced from different species of Cassia, and in the imported drugs leaves are sent which are very like the true ones, but which are useless. The difference, however, is easily detected by sharp eyes. The Cassia has compound leaves with very small leaflets, and in the leaf of the true Senna the two sides of the leaflets are unequal, one side being very slightly shorter than the other; if the sides are quite equal the true drug will not be produced.

Now the question naturally arises-Is there really any connection between the structure of a plant or colour of a flower and its medical uses? Is it possible that the aromatic scents of lavender or thyme can only be produced by a square 


\section{Medical Properties of Flowers}

stem, opposite leaves, and irregular flowers? Or that dangerous qualities cannot exist in such a formation, but require something very different, such as is found in Ranunculaceae? Or that true senna really depends upon a slight irregularity in the leaf? Such questions may be multiplied ad infinitum, and to each the same answer must be given that we cannot explain the connection but that it certainly exists; the facts are there, and we should not be much wiser if we could explain them, and we cannot.

But with respect to poisonous plants it may be well to note that a plant may be very dangerous in one state and quite harmless in another. Many of the poisons are very volatile, and disappear when the plant is dried, and in many cases when it is cultivated or cooked. In a hayrick many very poisonous plants can be found, all quite harmless in the dry state; and I suppose this is the explanation of the harmlessness of the large quantity of colchicum in the Alpine meadows. The colchicum is closely allied to the very poisonous veratrum, and when eaten fresh by grazing cattle it is very injurious to them; but when dry the poison may be destroyed. And not only can poisonous plants be thus made harmless, but in many cases they are fatal to man but not to beast, and fatal to some beasts and not to others. Pheasants will eat the acrid and poisonous roots of the buttercup, so that the author of The Pheasant, in the "Fur and Feather" 


\section{In My Vicarage Garden}

series, says that he dissected a cock pheasant in the month of June and found the crop full of the roots of the common buttercup. Lucretius noted this, and having said-

"Quod ali cibus est aliis fuat acre venenum"-

proved it by the statement that hemlock and veratrum were poisonous to every other animal, but that goats fattened on them, and that veratrum was also a fattening food for quails. I cannot say how far this is verified by modern observation, though I have asked for information from many; but I do not know in what part of Italy Lucretius made his observations.

It is an obvious truism that people are differently affected by poisonous plants, but it is hard to explain why it should be so. Leaving out of the question poisons taken knowingly for special reasons, many are variously affected by them in other ways. Some persons have been made seriously ill by sleeping under or near yew trees; and others have been still more distressed by even passing through tracts of the California bay, a bush with a very pungent scent, which in my own garden I have seen produce very unpleasant effects to some people, while to others it is nothing but a pleasant smell; and the poison oak of America will give headaches to some passing at many yards' distance, and to many has been quite fatal, while on others it has no effect; but it has such a decidedly bad character that I always 


\section{Medical Properties of Flowers}

advise its destruction whenever I meet with it, in spite of its beautiful autumnal tints.

It would be too long even to mention many other poisonous plants, however full of interest they may be ; but the upas tree cannot altogether be left out. We can many of us remember the dreadful accounts of this tree, which we were taught was one of the wonders of Java, and certainly the account of it, which was given by the Dutch Surgeon Foersch about a hundred years ago, was so circumstantial in all its details that it is not surprising that it was fully believed. Darwin naturally seized upon it, and in the Loves of the Plants gave a full account of it, beginning with-

"Fierce in dread silence on the blasted Heath Fell Upas sits, the Hydra Tree of death,"

and in the appendix he gave Foersch's account in full. But it is now known that the greater part was pure invention, and what was true in it was much exaggerated. Still there is such a tree in Java, Antiaris toxicaria, of the same family as the bread fruit and very poisonous; and the "blasted heath" in which it was said to grow is not altogether imaginary, for the trees grow in valleys which are unwholesome and even fatal to animal life, not by reason of the upas tree, but of the mephitic volcanic vapours escaping from crevices in the ground.

The Preacher reckoned among the qualities of the wise man "certain knowledge of the things 


\section{In My Vicarage Garden}

that are ... the diversities of plants and the virtues of roots," and on that high authority I think no apology is needed for writing on the scents of flowers, their virtues, and their uses. The more I study plants the more I feel that there is no part of a plant that is beneath our study, and whenever I meet with a brother gardener I like to tell him that, however successful he may be in growing plants and bringing them to high perfection of flower and fruit, yet he knows little of his flowers if he is content to stop there ; and that he misses a great deal of pleasure if he refuses to examine as far as he can every part of every plant he grows; and while I never met with a gardener who regretted spending some of his spare time in learning the minute history of his plants, I have met with many who have found in it not only much real pleasure and interest, but much also to help them in the practical cultivation of their plants. 


\title{
CHAPTER XV
}

\author{
RAILWAY GARDENS
}

THERE are two sorts of railway gardens. There is the railway-station garden, with which we are all so familiar, the long strips running parallel to the platforms, often wonderfully bright with flowers, and showing very good specimens of gardening under difficulties. For it is a very difficult thing to manage a garden often more than a hundred yards long, and perhaps not a yard in width, with a soil that in many cases is little more than rubbish shot there when the railway was being made, and always liable to ill-treatment and thefts from trippers and other thoughtless travellers. Yet in spite of difficulties there is scarcely a country station that does not show a pleasant and often quite a wonderful show of flowers, and wherever the stationmaster shows himself anxious to make his station smart and beautiful with flowers, he is sure to meet with ready help from the great gardens at the hall or the smaller gardens of the parsonage and other neighbours. There is another person besides the stationmaster who is gradually taking possession of railway-station gardens. Little by little nurserymen are finding out that it is a good 


\section{In My Vicarage Garden}

advertisement to take in charge the strips of garden on the platforms; and very bright they make them for us, and keep them so more or less all the year. I believe this originated in Scotland. Twenty years ago or more a large nursery garden near Dumfries station was allowed to overflow its bounds and to fill the side approaches to the station with gay fllowers; and English nurserymen are slowly following the example, to the great advantage of -English travellers, and, we may hope, to their own advantage.

But it is not of railway gardens planted and kept in order by stationmasters and porters, or by nurserymen, that I now wish to speak. My subject is railway gardens planted and kept beautiful by nature. These gardens are getting well-established all over the country, and if as we travel we will note the flowers on either side of us we shall often see much to delight and interest us, and in many instances we shall see some results that are very curious.

What I mean is this. When a railway is first made, the line is bounded either by the sides of a cutting, or by an embankment falling away from the line, or by a broad, flat verge; but whether it is a cutting, or an embankment, or a verge, the result is raw, bare, and often ugly. But nature does not allow it to remain so for long; in a very short time the bare sides get clothed, and often before a year is past the surface is fully covered 


\section{Railway Gardens}

with a vegetation entirely of nature's planting. In a few cases, where the ground is treacherous, the sides are planted with plants of different kinds that will help to hold up the shifty soil; but in the greater part of the line the clothing is all natural. And then this curious result followsthat the sides of a railway are found to be safe places for many plants which in other places have to fight their way against many difficulties; for the sides of the railways are not eaten down by cattle or sheep, and they are very little trespassed upon, and so plants get a good chance of growing and getting well-established; and railway gardens are formed, planted by nature, and often furnished with plants that are unknown to the immediate neighbourhood, and that are in some cases rarities in the British flora-and these are the railway gardens of which I wish to say something.

It is, indeed, marvellous how very soon the bare, raw face of a railway cutting or embankment will get fully clothed with plants. On the Midland Railway, between Bath and Bristol, a deep cutting showed a vast cliff of red sandstone known to be of very great depth, and butting up against it was a series of liassic formations of various ages, such formations not lying horizontally, but forming a succession of concavities lying one upon another, and with the intervals filled with liassic clays. It was easily seen, was visited by many geologists, but only for a short time; within 


\section{In My Vicarage Garden}

eighteen months the whole was so covered with vegetation that for geologists the view was closed.

Now in all cases of railway sides covered by vegetation the commencement is made by seeds blown from the neighbouring fields and hedges, which find soil ready for them, and being undisturbed, grow up speedily and vigorously. But there are a great many which cannot be thus accounted for, many which are new to these fresh localities, and many which will, in time, alter the floras of different neighbourhoods, and in some cases have already done so. Some of these instances of plants appearing in new places I will now give, confining myself to the railways.

One of the most curious instances is the case of the London rocket (Sisymbrium irio). It appeared abundantly in London after the Great Fire, and then disappeared. The only other place in which it had been constantly noted was at Berwickupon-Tweed, where it still exists on some rubbishheaps outside the town. Earth from the rubbishheaps has constantly been carted on to the different fields, but the rocket never appeared in them, but-

"In I847 a large quantity of earth was taken from an adjoining field, where the irio was never known to grow, and used to make the embankment on which the station of the North British Railway partly stands. The irio grew up in front of the bank in great profusion immediately."Johnston, Botany of the Eastern Border.

It did not remain many years in that particular 136 


\section{Railway Gardens}

spot, but I am told that it still at times appears on other parts of the railway embankment; otherwise it is quite confined to the rubbishheaps.

In a cutting on the North Kent line, near Gravesend, the sides of the cutting for nearly two miles are completely covered with wild Valerian. When they are in flower it is a most beautiful sight, and almost worth a special journey to see it. The flowers are of all shades of red, from the palest pink to deep crimson; white specimens have been reported to have been found among them, but I have not seen them. The same valerian clothes very prettily a deep cutting near Chepstow, but there it is mixed with other plants, and so the mass of colour is less, but it is sure to increase, and may in time fill the whole cutting. This valerian is a British plant, and fairly common, so that it is not surprising to find it on almost any place; but my two next examples are something of a surprise.

On the London Chatham and Dover Railway there is a cutting near Sole Street station, not very deep but with steep rocky sides: these sides being, of course, rather roughly hewn have several narrow ledges and other "coigns of vantage." These have been taken possession of by the garden Canterbury Bell, both white and blue, though the name "Canterbury Bell" was originally given to our wild plant, $C$.trachelium, because " it grows very plentifully in the lowe woods and 


\section{In My Vicarage Garden}

hedge rows of Kent" (Gerard). Yet it is more generally applied to the garden Canterbury Bells, C. Medium, and this is the plant which is so abundant in the Sole Street cutting. It is not a British plant, but is found chiefly in the south of France, and is also found in Italy and in Turkey. There seems no reason why it should not become perfectly naturalised in its new railroad home, though it may be a great puzzle why it has not found a congenial home long before this, for it has been a favourite in English gardens for three hundred years, having been grown both by Gerard and Parkinson. I do not know the reason for the name given to the plant by Linnæus, $C$. Medium, but the name of one fine British bell flower, $C$. trachelium, is directly from

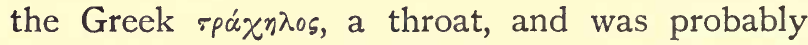
adopted from its older English name, throatwort, "because they are excellent good against the inflammation of the throate and uvula" (Gerard). Another foreigner has completely established itself on an embankment of the Great Western, near Bath. This is the giant parsnip (heracleum villosum), a native of the Caucasus, and in this case it is known to have been an escape from the garden of the engineer who made that part of the line. It is a grand plant, and seeds very freely and is a troublesome weed in gardens, but on the railway embankment it is a great ornament.

On a rough barren piece of ground near one of the stations of the Midland Railway, between 


\section{Railway Gardens}

Bath and Bristol, I have this year seen with much pleasure a goodly patch of the viper's bugloss (Echium vulgare). This plant is not uncommon in many parts of England, especially in the chalk districts, but it is a very rare plant in the Bath and Bristol flora, so rare that only two stations are given for it, and in those stations it is far from abundant; yet it has found a suitable home on this railway bank, and will very probably increase and multiply there. When I say that I have been much pleased to see it, it is because I consider it one of our most beautiful British plants; the union of azure blue, with red in the same flower, is very unusual and very beautiful. The spotted stem suggested a viper's skin, and the seed was supposed to be like a viper's head, and hence the name, and in the days of the doctrine of signatures it was considered a safe remedy against the bite of vipers, as it still is in Spain and Portugal.

We cannot suppose that plants can in any way choose their habitats, but we can easily see that if by chance a seed should light upon a spot which was at the same time not easily reached by man or beast and had suitable soil it would there at once take root and flourish, and this must be the explanation of the occurrence of plants in unexpected places, as railway banks and cuttings, and there flourishing with unwonted vigour. The finest bee orchis I ever saw was at the top of a deep cutting through a sandstone rock; it was 


\section{In My Vicarage Garden}

not exactly a railway cutting, but it was a road cutting made to divert a road for a railway, and so may find a place here. Orchids seem especially to look for a quiet and undisturbed place; they dislike removal, and require great care in growing after being removed from their old quarters, and such quiet places they seem to find in railway embankments and cuttings. I have seen good plants of $O$. pyramidalis in a cutting on the Great Western between Bath and Bristol, and this orchis is very scarce in the immediate neighbourhood, though it is abundant in some parts of the Cotswolds, perhaps twenty miles distant. In the same neighbourhood I have seen the handsome large butterfly orchis growing close to the rails. This grows in woods near at hand, but not abundantly; and I never saw one outside these woods till this one found a quiet resting-place that suited its wants as well as the quiet of the woods.

In another way it may happen that in years to come the railway will be a record, and, perhaps, the only record, of the nature of the country as it originally was before the railway came to it. I know of one piece of railway that passes through an old common. Little by little the common is getting covered with cottages, and the flora is getting entirely destroyed by donkeys and other animals, and by constant traffic. But between the two hedges of the railway the old flora of the common has well established itself, and is spreading in such a way that there is little fear of its 


\section{Railway Gardens}

being destroyed; and what a few years ago was bare earth and rubble is now covered with the heather, the dwarf autumnal gorse, the small campanula, and other heath plants.

These few instances will be enough to show how even railroads may have their uses in preserving to us many plants that might otherwise be lost, sometimes altogether, and sometimes from particular districts ; and I could have added others. Very remarkable is the way in which even our common plants get an increased luxuriance when they find a home within the boundaries of a railway. There are many places in which primroses and cowslips may be found in abundance in the fields and hedgerows, but whenever I see them so growing I fancy that they are always finer when they have fixed themselves on the adjoining railways. I cannot say for certain that it is so, because it is not always possible to make the actual comparison when travelling; but so it has often seemed to me as I pass them, and I have found that fellow-travellers have made the same remark. It is only natural that it should be so ; a plant that is constantly eaten down by cattle will never attain the same luxuriance as one of the same sort that is untouched on a railway bank or in a secluded wood.

How plants have the power of migrating and finding for themselves new and suitable homes in fresh localities is a very good subject for inquiry ; but that they have the power is matter of common 


\section{In My Vicarage Garden}

everyday observation. Where the plants found on railways are the plants of the adjoining woods, fields, and hedgerows, the explanation is very easy. A slight wind or a few birds will soon carry seeds enough to stock a large place; and in some places the wind or the birds have carried the seeds from gardens more or less near, as must have been the case with the Canterbury Bell on the London, Chatham, and Dover Railway, which I have described. But this will not explain it all; and I am sure that the full explanation can be found in the fact that nature seems, as it were, always on the look-out for places in which plants can find an abiding home. If plants were confined to cultivated spots only, or if they depended on man only for their dispersion and cultivation, there would indeed be more tracts barren and desolate than of well-clothed country ; but, as Sir Thomas Browne said, "the whole earth is the garden of nature, and each fruitful country a paradise," and there are more gardens and paradises planted by nature than by man. And Sir Thomas Browne also noticed how independent of man nature is when he said :-

"The seminal powers of plants lie in great part invisible, while the sun finds polypody in stone walls, the little stinging nettle and nightshade in barren, sandy highways, scurvygrass in Greenland, and unknown plants in earth brought from unknown countries."

With a slight modification "earth brought from unknown countries" explains the existence of 


\section{Railway Gardens}

many plants found on railways. Embankments are often made of materials brought from a great distance, and the embankment is of a very different nature from the surrounding ground on which it is raised; and in the materials are often the beginnings of the vegetation which in time will clothe the embankment either in the shape of roots or buried seeds. Then comes in the other great factor of success in the full growth of the vegetation so commenced, that it is from the very first undisturbed, not grazed on by cattle, and little trespassed on by man.

Geologists have long recognised that one of the greatest helps to geology in recent times has been found in the railways. During the last seventy years wonderful geological sections have been brought to light which would, but for the railways, have been entirely buried; and from these sections many new lessons in geology have been learned, and if many old theories have been destroyed, many substantial truths have taken their place. The service which railways have given to botany is different. They have not revealed new plants, but I am sure they are doing much to preserve old ones, and this result is none the less pleasant because it was unexpected and unintended. When contractors complete a railway, nothing can be much uglier in all the parts where old soil has been disturbed, or new brought in; but the railway is not completed when the contractors leave it-Nature then takes it in hand, and, with its 


\section{In My Vicarage Garden}

dislike to all that is ugly, it seizes on each vacant piece of ground, brings to it from every quarter seeds and even roots, and in a very short time clothes it with beauty that, being undisturbed, will be the inheritance of the railway as long as the railway itself lasts, and will make our railways as happy hunting-grounds for the botanist as they have been for the geologist. ${ }^{1}$

${ }^{1}$ A writer in The Globe (in 1898 ) confirms this. He says, "A Londoner would have to walk many miles before he encountered such an assortment of wild plants as that which he can inspect along the railway banks, for example, between Gloucester Road and Earl's Court Station. . . . A wealth of plants which are associated with hedgerows along country roads is to be found which somehow or other have fought their way into the wilderness of bricks and mortar." 


\section{CHAPTER XVI}

OUR NATIONAL GARDENS

A VERY busy Londoner once told me that he thought it the duty of every Londoner to go once a week to Kew, not merely to please his eyes, but as the readiest and nearest place of refreshment to his body, with the opportunity of slowly taking in small lessons on many subjects. Such an exodus from London to Kew would overtax even the resources of Kew ; but it is surprising to find how very few Londoners, whether residents or visitors, have any real acquaintance with a place open to all, within an hour's drive of London, and which is unsurpassed by any similar establishment in the world. Many who pride themselves in seeing everything that is to be seen in London, and knowing everything that is worth seeing, have never been to Kew; and I have often found that the real hindrance to their going is in some cases that it does not rank' as a fashionable lounge, but far more from a complete ignorance as to what is to be seen at Kew, and how it can best be seen. I think that some short account of it may be useful, and may perhaps tempt some to see for themselves a part of our national property of which every educated Englishman may feel proud. 


\section{In My Vicarage Garden}

There are, of course, some, and perhaps not a few, who think that to spend the money of the nation on a garden is a waste : they would at once disestablish and disendow all public gardens; but I am sure that such persons are in a minority, and a quite insignificant minority, not only among Englishmen, but among all civilised nations. To establish public gardens would certainly not be the first care of any rising State; but it is found to be almost the first when the foundations have been well laid, and there is nothing that shows that a nation has reached a high state of civilisation and a state of stability as the formation of public gardens. "A man shall ever see," said Bacon, "that when ages grow to civility and elegancy, men come to build stately sooner than to garden finely, as if gardening were the greater perfection ;" but the fine gardens soon follow upon the stately buildings. It does not seem to be known for certain what European State first led the way in the formation of public gardens-i.e. of gardens maintained by the State. Hallam says that the first public garden was founded at Pisa in I 545, and a somewhat earlier date has been claimed for a similar garden at Padua; but, though these may have been public gardens, they were attached to Universities, and do not seem to have been maintained out of national money. Prescott, however, has told us that long before this public gardens of great excellence and beauty were established in Mexico, in which not only were the beautiful 


\section{Our National Gardens}

plants of the country cultivated with great skill and care, but plants were collected from many other countries, and these plants "were systematically arranged by the Aztecs, who understood their properties, and collected them into nurseries, more extensive than any then existing in the old world." In England the Physic Garden at Oxford and the Apothecaries' Garden at Chelsea led the way as public gardens, but they were not maintained or even helped by the public purse.

The beginning and progress of Kew as a public and national garden have an interesting history. A little more than a hundred and fifty years ago the whole property was in private hands, but even then the gardens were reckoned among the best in the country. After being leased to the Prince of Wales, they were bought by George III., and under the able advice of the Earl of Bute and the management of the Aitons the character of the gardens was well maintained, but they were in no sense public property. After some years' neglect they were placed under the care of Sir William Hooker, and to some extent were opened to the public. From that time the progress has been steady; by the liberality of the Queen the size of the gardens has been increased from the twelve acres which were opened to the public in I 840 to more than 300 acres; and under the skilful, and we may say the loving, management of Sir William Hooker, Sir Joseph Hooker, and the present director, Sir W. Thiselton Dyer, the 


\section{In My Vicarage Garden}

gardens have been brought to a very high pitch of excellence, and have been arranged and managed with a constant eye to the instruction and comfort of the public.

Such is a very short account of the rise and progress of the gardens to their present state, leaving untold the many ways by which the gardens and museums have been furnished from all parts of the world by purchases in many cases, but still more by gifts from persons of all ranks and conditions, till it may safely be said that nowhere in the world can the vegetable products of all parts be more easily and more perfectly studied.

But the gardens are not only for botanical students; they contain a wealth of flowers which give pleasure to thousands who have little or no scientific knowledge, while their beauty alone will be a pleasure to many others. Still, as I said before, there are many living within easy reach of Kew who know nothing of it, and there are some, or rather many, who go to Kew and come back without having seen a twentieth part of the garden, and with an ignorance of the contents which may almost be called absurd. But it is a large place, and unless a person goes there with guidance of some sort, and also with some definite idea as to the special objects which he wishes to see, he may come away quite disappointed ; and I have known a clever man who went there and asked for the Botanical Garden, and, having seen the scientifically arranged portion to which he had been 


\section{Our National Gardens}

directed, and which lies near one of the entrancegates, he fancied he had seen everything, and naturally came away with the idea that the great national garden of which he had heard so much was very small and very ugly. A guide of some sort is necessary. If the stranger can go under the guidance of one who knows the garden well, that will be the best; if he has no one who can personally conduct him, he may buy one of the guide-books on sale at the gates, and with some little trouble he may choose for himself the parts that he most wishes to see. But almost every visitor will have a different object in view; and if I was asked to conduct a friend I should not take him to the parts which I most liked myself, but should find out what branch of botany or gardening he most wished to study. If, for instance, he wished to know something of the scientific arrangement of plants I should take him to the strictly Botanic Garden, where plants are arranged according to their families in long narrow beds, each bed representing a particular family, and containing good typical plants of the families; but I should not take any but a scientific student there, for the garden is necessarily stiff and ugly. If he wished to know something of the plants used in medicine or commerce-something of the economic uses of plants or their commercial products-I should take him to the Economic House, in which are grown, but in a very limited space, many of the plants that are most useful to mankind, such as 


\section{In My Vicarage Garden}

fibre plants and plants producing chocolate, tea, coffee, cinnamon, cloves, cotton, ginger, guttapercha, Indiarubber, strychnine, pepper, quinine, sarsaparilla, etc. But I should not consider that I had shown him all he ought to see in this department unless I had also taken him to the museums, in which the many products of the vegetable world are shown in their raw states, in the different processes of manufacture, and in their final results. If he wanted to know the best plants with which to stock his garden for purely ornamental purposes I should take him to the Rock Garden. I consider this one of the great successes of Kew, by which I do not mean that it is the best example of what a Rock Garden should be, and might be, but I consider it a very successful example of such a garden in a public garden, for the requirements of a public and private garden are essentially different. In a private garden the rock garden may be in a retired spot, with small tortuous paths, some of them leading to nowhere in particular, with small nooks and pleasant surprises, ups and downs, and a general wildness. In a public garden all this is impossible. The paths must be wide enough for many at once going, it may be, in different directions ; the plan must be clear and well defined; and the plants named with conspicuous tallies. The idea of the Kew Rock Garden is the dry bed of a small river, such as abound in Spain in summer, of which the bottom forms the path and the sides 


\section{Our National Gardens}

are clothed with flowers. It was made in I $88 \mathbf{I}$, chiefly in consequence of a memorial to the Board of Works from many lovers of gardens, and after some difficulty a grant was made, and, though it was a wretchedly small grant, it has certainly enabled Kew to grow and show to advantage a large number of plants which were grown before with difficulty and were not well shown. Of course, it does not please everybody; objection is taken to the wide and very conspicuous path, to the uniformity in height of the sides, and to the presence of conspicuous labels, which destroy any attempt at an appearance of wildness; but such objectors should remember the peculiar difficulties of such a work in a public garden, and the small amount of money spent upon it. Another excellent addition that has lately been made to the hardy garden is the new Bamboo Garden. It is placed near one of the prettiest parts of the garden, near the dell full of rhododendrons, and very near the river; this, too, though still young, is a great success, and it has already given good object-lessons to the many who now grow bamboos. Not only does it show the complete hardiness and easy cultivation of many species, but it has pointed out a way of cultivation of which many growers were ignorant. It has been quite a lesson to many of us not only that bamboos delight in a large supply of water, but that they are gross feeders, and should have a supply of manure to which there seems to be almost no limit. This 


\section{In My Vicarage Garden}

had been very little done before by bamboogrowers, but when we recollect that bamboos are only gigantic grasses, and that on account of their gigantic character they are very exhaustive to the soil, the reason of the thing is at once acknowledged.

But to return to my imaginary friend. If he was laying out a garden of some extent for the first time, in which he was anxious to grow good trees and shrubs, and was in despair at the monotonous way in which nurserymen contract to lay out gardens, planting them chiefly with laurels or with any other shrub of which they happened to have a supply, then I should say that an afternoon at Kew would give him many good hints. There is sold at the gates a plan of the garden, by which it will be seen that while shrubs of all sorts are dotted about the garden in every direction, yet that there are many large families of which the different species are collected together in near neighbourhoods, so that the visitor can decide not only what is the best species in itself, but alsowhich is of more practical consequence-the best for his immediate purposes. Thus in one part there is a large collection of hollies, all separately named; in another, a collection of maples, much enriched of late years by the Japanese maples; in another, a collection of Berberis, many of them very beautiful; in other parts are collections of heaths, cratœgus, roses in their many species, mostly single, brambles, spiræa, honeysuckles, ribes, 


\section{Our National Gardens}

hydrangea, etc. ; while if he wanted a good collection of climbing plants, there is a charming collection of clematis trained to poles and chains, and a most interesting collection of vines also trained on poles and chains, which will be a pleasant surprise to many whose one idea of vines is connected with grapes.

But even if my friend wished to confine his attention to the hardy plants, I should not keep to the open-air garden only, especially if his own garden was in the south or west of England. I should certainly take him to the Temperate House. This is a large house and a very delightful one, filled for the most part with plants from Australia, New Zealand, China, Japan, the Himalayas, and other parts which produce plants which we can often grow out of doors, but which for the most part are doubtfully hardy. The real delight of the house is in the luxuriance of the growth and the way in which the plants rejoice in the temperature and in the care with which they are watched and treated. The whole space is divided into narrow beds, with good wide paths between them, but there is nothing stiff in this arrangement, for, owing to the luxuriant growth of the plants, it is seldom easy to see more than one path at a time. There may be seen immense tree ferns, palms, fuchsias to the top of the house, a large number of climbing flowering plants, etc., while the beautiful Sikkim rhododendrons, which seem to revel there, are alone worth a visit in their season. 


\section{In My Vicarage Garden}

I am not writing a guide to Kew Gardens ; I am merely indicating a few salient points which an intelligent visitor with limited time at his command would be glad to see. But it is really impossible to see it in one visit, and probably the best way for any one to see it properly would be to confine himself to the out-of-door garden on one day, keeping the houses for another. The houses are quite a day's work by themselves; indeed, no one should suppose that they have seen Kew till they have spent many days both in the out-door garden and in the houses. The Water House is always pretty with different water-lilies, papyrus, Egyptian lotus, hedychiums, and many lovely creepers. The great palm-house is, I believe, the finest of the sort in Europe, and I was once told by a friend who was well acquainted with the tropics, that nothing recalled the tropical jungle to his memory so much as the view in the palm-house from the upper storey; while the conservatory is kept constantly supplied with different flowering plants, many of them giving good lessons in cultivation, and very suggestive for those whose delight is in the bright colours of a well-kept conservatory.

I can say nothing of the many other housesspace forbids; nor can I say what I could have wished to say about the park-like beauties of the outer garden ; many parts of it are equal to some of our best parks, and there are individual trees which are unsurpassed elsewhere. Some of the 


\section{Our National Gardens}

beeches are magnificent; an oak and a Spanish chestnut near the lake are perfect pictures. The Salisburia near the fern-house is one of the largest in England, but the beauty of its shape has been spoiled by its having been originally grown against a wall; and not far from it is a grand hop hornbeam-the finest I know. But to name all the trees worth noticing would be beyond the object of this paper.

I mentioned the museums; they are full of interest, and, as everything is well labelled, they can be examined with comfort; and to most of us the manifold uses to which plants are put would be surprising. The palms and bamboos alone would give good study for an afternoon or more; but among the buildings two must be mentioned. The North Gallery is comparatively a recent acquisition, founded, built, furnished, and endowed by the late Miss Marianne North. The furniture consists of a complete series of paintings of the vegetation of almost the whole world, for the most part of a uniform size, and full of instruction, conveyed in the pleasantest way; and another complete series of polished woods from all parts of the world. The other building I allude to is the Herbarium, in a large red brick building just outside the chief entrance; and I mention it because no account of Kew is complete without some reference to the enormous amount of scientific work that is carried on in that building. It is not so open to the public as the other 


\section{In My Vicarage Garden}

departments, but perhaps there is no part of the institution which does more useful work for the public. Plants are named there for all inquirers in the most patient and liberal way, and though Kew generally is under the Board of Works, yet it is much more in contact with the Colonial Office, which sends to Kew endless inquiries about the colonial products, and depends on Kew to supply the colonies not only with all information that may be useful to colonists, but even with plants in sufficient number to enable the colonies to start and develop new industries, such as tea and cinchona in India.

I said that Kew was now a national garden, by which I meant that the expenses were borne by the nation. To some the amount granted may seem large, but I believe it to be one of the cheapest of our national institutions, when we consider the size of the gardens, the great care skilfully bestowed on them, and the very large amount of national and colonial work carried on there. Chancellors of the Exchequer are bound to keep a tight hold on the national purse; but I never recollect the vote to Kew being disputed in Parliament or objected to when once it had passed the ordeal of the Treasury; and certainly the most economic M.P. would find it hard to suggest any great economies at Kew, or to say that the salaries paid to the officials were overpaid sinecures. And Kew is not our only national garden. Edinburgh has a beautiful garden, in ${ }_{15} 6$ 


\section{Our National Gardens}

which many plants, especially some of the New Zealand plants, are grown in greater perfection than they can be grown at Kew, and Ireland has a very pretty and well-managed garden at Glasnevin, near Dublin.

But because Kew is entirely supported at the national cost, the public think they have a right to growl if everything is not done to their complete satisfaction, and in more than one particular the growling is somewhat unreasonable. I will mention two such. A demand has been frequently made that the garden should be open to all from the earliest hours; it is now open to the public at twelve and to students and others earlier, by permission (easily obtained). One objection to the earlier opening is that it is not only or chiefly a pleasure garden, but above all a scientific establishment, and the earlier opening would seriously interfere with the scientific work. But another objection is that Kew is rapidly becoming a residential suburb of London. Numberless new houses have been built, the population has increased largely, and if the gardens were opened in the morning they would be invaded by children of all ages, with the necessary accompaniment of nursemaids and perambulators, and the interference with the work of the gardens, the greater part of which is done in the forenoon, would be very serious. Another growl may sometimes be heard that people cannot get from Kew flowers or plants to the extent that some think they are 


\section{In My Vicarage Garden}

entitled to. To this the answer is that no public garden could admit such a claim, and that at Kew the officials are not the owners of the plants, but trustees for the nation, and they have no right to give flowers or plants away merely to please themselves by pleasing their friends. But as trustees they have to improve and extend the property, and when they can do so by exchange of plants or by giving plants to others who will help the work at Kew by growing plants which are not easily grown there, or by helping in the scientific study of the plants, they are not found to be illiberal.

It is worth mentioning that gardening is carried on at Kew under great difficulties. The soil is a wretched one-in some places little better than a sea-shore-and the steady increase of houses between it and London is bringing a large supply of London smoke. But in spite of these and other difficulties the work goes on steadily and successfully, and every year it seems to be growing in popular favour; so that on Bank Holidays the numbers are often over eighty thousand, and it is pleasant to record that very little damage is done to the garden, and the conduct of the many visitors is very rarely open to complaint.

From what I have said it may be supposed that I have a very high opinion of the value of Kew as one of our best national institutions; and though I do not go so far as to say that every 


\section{Our National Gardens}

Londoner should go once a week there, yet I am sure there are many who now know it not, but would find much pleasure in a visit; and to all my brother-gardeners I should say, go to Kew as often as you can, but do not go in a fault-finding spirit, or come away with the boast that you can grow many plants better than Kew can; but go to learn, go to enjoy yourself with the sight of many treasures that you can see nowhere else, and you will come away with the boast that England can show a national garden which has no equal anywhere; a garden not only the richest in plants, but one in which visitors are welcomed and helped, and their comfort looked after in a way which they will look for in vain in any public garden outside Great Britain. 


\section{CHAPTER XVII}

THE FLORA OF ENGLAND EIGHTEEN HUNDRED YEARS AGO

IF one of our British ancestors who lived in the year A.D. I o० could now revisit his native land, what difference would he find in the natural features of the country? It is an interesting question, the answer to which may tell something of the way by which the England of our day is what it is ; and I fix the date at A.D. Ioo, because at that time the Roman occupation was fairly established, yet the Roman colonists had scarcely had time to effect many changes, and for the sake of convenience I will limit the question to the country south of the Trent.

Of course, I put aside all human works and buildings, and confine the question to the natural features, and within that limit it will be found that the changes are not so many as some of us might fancy. The great natural features of the country are the same, the hills, valleys, downs, etc. In some places there have been changes of the coast line, a gain from the sea in one place, and a loss to the sea in another, but the effects of such changes do not stretch far inland. Some I60 


\section{The Flora of England}

rivers have silted up, and are no longer navigable, as they were in A.D. IOO and much later; and parts of the country which were at that time large tracts of fen or extensive morasses or marshes, have been converted into good and useful land, either by artificial drainage or by natural silting up. At that time, also, there were immense tracts of forests, which had their uses not only in the production of timber, but also, like the great fens, as natural defences between one tribe and another; and this abundance of large forests must have had its effect on the weather and climate, producing certainly a larger quantity of rain all through the year. In those respects the natural features of the country have been changed, and the drainage of the country and the destruction of large tracts of forest must have had a great effect upon the rivers; for it is certain that more rapid though shorter floods are now the rule, producing the further effect of deepening the rivers, and preventing the long continuance of shallow floods on the low-lying lands adjoining the river banks, and in that way much lessening the cold arising from constant fogs.

These changes of the natural scenery have done something to make the England of the nineteenth century different from the England of A.D. roo, but after all that is said, the changes from this point of view, though important, are not very many. It is very much the same if we compare the fauna of the two periods. Some 


\section{In My Vicarage Garden}

few animals have been lost from the British fauna. It is generally agreed that the great ox or Urusbos primigenius - was extinct in Britain before the Christian era, though it was certainly in existence in the Iron age, and probably later; whether it still exists in our domesticated cattle is a subject upon which naturalists are divided; but if it does, there can be little doubt that in A.D. IOO the domestic cattle were more like the old Urus than they are now. Cæsar described it as still existing in his day in the Hercynian Forest, but whether he had ever seen it himself is not quite clear from his description; but he tells us it could not be tamed. He says it was as big as an elephant, with the colour and shape of a bull, and he says “Magna vis eorum, et magna velocitas" (B.G. vi. 28), and probably Pliny copied from him, describing them as "excellenti et vi et velocitate uros" (H.N. viii. I 5). Altogether he must have been a wild beast that we can well spare from our present fauna. Besides the Urus, three other animals are now missing from our fauna that were in Britain in A.D. IOO, the beaver, the bear, and the wolf. The beaver was probably never abundant, and was confined to a very few rivers, but it is certain that it could still be found in some of the Welsh rivers as late as the eighth century or later. British bears are said by Plutarch to have been imported into Rome, and were much admired, but they probably only existed in the northern parts of the country, where they are recorded as 


\section{The Flora of England}

late as the twelfth century; in the southern parts there is no record of them, and they are now represented by the harmless badger. But wolves were probably abundant; the great forests would have given them all the shelter they required, and when we see how they still live and increase even near the most civilised parts on the Continent, it says something for the vigorous way in which their destruction was carried out in England, that for at least six hundred years they have entirely disappeared, though in Ireland they still remained till the beginning of the eighteenth century. These are the chief large animals that mark the difference between the two periods; all our other mammalia are the same, some slightly altered by years of domestic training as domestic animals, but in the wild animals there is probably little or no difference. In one point, however, there is a curious difference between two animals, looking at them as articles of food, the fox and the hare. By the early Britons the fox was certainly eaten, while the hare was never eaten by them-leporem gustare fas non putant (Cæs. B.G. vi. I 2), as it is still not eaten by the Laplanders; with us the hare stands high as a food, while I believe not even a gipsy would eat a fox. With the birds the case is very much the same; there is very little difference between the wild birds of the two periods. There are some introductions, as the pheasant, the turkey, and the guinea hen, and we now eat the goose and the hen, which the ancient Briton did 


\section{In My Vicarage Garden}

not, though he kept them as domestic pets animi voluptatisgue causâ. I fear we must now look upon the great bustard as a lost English bird, though it has been fairly abundant in some parts within the memory of man, but with that exception I believe we have all the wild birds that our old British ancestors had, and that the birds we now have are identical in every respect with the birds of the first century. This is rather curiously shown to us by the names of our birds, which also show that our forefathers must have been good observers - at least, good enough to name the birds they saw. For nearly all of our birdnames are not only very old names, but they rank among the oldest words of the language; they are old British names, very little influenced by the names of the same birds that were familiar to the Roman colonists of England. It is the same, too, even with the insects ; they are probably exactly the same with very few, if any, introductions or losses; and of the insects, too, the names are very ancient. Many of our insects carry very old names ; "chafer" and "butterfly," for instance, occur in an eighth-century list, and "butterfly" is a name for which even Dr Murray can give no derivation whatever in the New Dictionary; it is a genuine British name without any foreign admixture. It is the same, too, with our fishes and reptiles.

But it is time that I said something of the Flora of Britain Eighteen Hundred Years Ago, I64 


\section{The Flora of England}

for that is the title of my paper. I said that Britain was in many parts covered with extensive forests; for what was said of Buckinghamshire in the eleventh century, abundabant eo tempore nemora spatiosa densa et copiosa, must have been the case to a much larger extent all over England a thousand years earlier, though it is known that the Romans cut down large tracts of forest for military purposes. This abundance of forests no longer remains to us, but the trees of which they consisted are the same. Among these the oak would be, as it is now, the monarch of English trees; and it was probably the most abundant, for it is almost certain that the great forests were oak forests. But the ash must have been almost as abundant, and far more abundant in the country south of the Trent than it is now; this is shown by the large number of places in southern England which get their names from the ash, but in which the ash is no longer the leading tree, and in many of them it is almost extinct. These were probably the two chief forest trees of Southern England in the earlier period I have named; among the less important trees were the birch, the alder, the wych-elm (in the north more abundantly), the maple, the willow, and perhaps the yew. These are generally now considered to be truly indigenous and have old British names; and among smaller trees the holly and the mountain ash were probably abundant, the holly certainly, but the mountain ash more abundant in I 65 


\section{In My Vicarage Garden}

the north than in the south. The great difference in large trees between the two periods in the south of England would be the beech, the Scotch fir, the walnut, the Spanish chestnut, the horse chestnut, the sycamore, and the elm, and all of these, except the horse chestnut, may have been introduced by the Romans. In the south of England the Italian elm, now our common elm, has been the chief agent in disestablishing the ash; and its name, in Old English, "ulm," or "ulme," seems to be an additional proof of its introduction by the Romans, though etymologists now consider that "elm" is rather cognate to ulmus than derived from it. But whenever introduced it does not seem at once to have spread so rapidly as it now does, for in Evelyn's time it was still a scarce tree beyond Stamford. When or by whom the sycamore was introduced into England is not known, but it was fully established in the sixteenth century. It grows wild in Italy, but not far south in any abundance. The horse chestnut is so late an introduction that it is not admitted into the English Flora, even as a naturalised plant; yet it is a European plant, being found in the Pindus range of mountains in Turkey, and it was introduced into England in the sixteenth century from the Levant. Like the sycamore, it found a congenial soil and climate in England, and soon so firmly established itself that Evelyn, writing in I 662, said of it:- "It grows so goodly a tree in competent time, that by this I 66 


\section{The Flora of England}

alone, we might have ample encouragement to denizen other strangers amongst us." It is in no way related to the Spanish chestnut, but the similar appearance of the fruits gave the name, while their uselessness was emphasised by the prefix "horse." The walnut is not even a native of Europe, though there can be little doubt that it was introduced into England by the Romans, and took kindly to the soil, and at once proclaimed its foreign origin by its name of walnut, originally welch-nut, a name which it still keeps in some parts of England. The Spanish chestnut speaks for itself that it is a foreigner, and the two remaining trees, the beech and the Scotch fir, are especially interesting, because Cæsar expressly says that the beech and the Abies are the only Gallic trees that were not in Britain; but what he meant by Abies is by no means certain and cannot be discussed here. What is certain is that we have now large beech woods, especially in the chalk districts, some of which may have taken the place of the older oak forests, and that in the south we have large tracts entirely occupied by the Scotch fir, that, if unchecked by browsing and other means, would very soon overgrow all other vegetation. The extreme rapidity with which the Scotch fir takes possession of a country, when left to itself, is very pleasantly told by Charles Kingsley, in his Winter Garden-(Miscellanies, vol. i.).

"Thousands perish yearly," he says, "but the eastward I67 


\section{In My Vicarage Garden}

march of the whole, up hill and down dale is sure and steady, till as you stand upon some eminence you see stretching to the eastward of each tract of older trees a long cloud of younger ones, like a green comet's tail."

The forest trees have detained me too long, for I must say something of the fruit trees and vegetables. I have already mentioned the walnut and Spanish chestnut as foreign trees, which were certainly not in Britain in A.D. IOO. We can certainly say the same of the almond, apricot, fig, medlar, mulberry, nectarine, peach, pear, quince, most of which were introduced in the sixteenth century, though the pear, and perhaps the fig, may have been introduced by the Romans. The common fruits, apple, gooseberry, currants, raspberries, and strawberries, are all descended from our native fruits.

In vegetables there has been a great change, for the vegetable garden of the ancient Briton must have been very poorly supplied, and probably he paid very little attention to it. The Roman colonists may have made him acquainted with peas, beans, and onions, but the bulk of our present vegetables date from the sixteenth and seventeenth centuries, and it is a curious thing that with all our commerce with foreign countries, and the strong desire to get new things, scarcely one new vegetable has really been established among us since that date. The rhubarb was introduced as a culinary vegetable during the last century, but the plant was grown in England long 


\section{The Flora of England}

before; and for three hundred years no vegetable has been introduced that can in any degree compare with the results, commercial, agricultural, and even political, of the potato. Nor can it even be said that the vegetables as now grown are very different or much better than those grown by our forefathers. In a few instances varieties have been introduced which are more prolific, or in some respects more profitable, but in spite of the nurserymen, whose catalogues announce novelties and improvements every year, the plants practically remain very much the same, and those who can look back fifty years or more are very positive in their assertions that the peas, asparagus, potatoes, etc., which they ate in their youth, were in no way inferior to what they get now; some even will go further, and say that they were superior, for that now everything, flavour included, is sacrificed to size.

I have left myself too small a place to speak, as I should have wished, of the native Flora other than trees and vegetables, but I must not pass it by altogether. I do not suppose that the ancient Briton was much given to ornamental or pleasure gardening. The necessities of life would have compelled him, when he was not hunting the wild animals for food, to give his attention almost entirely to the plants that were necessary for his daily bread, such as wheat, barley and oats. Nor do I suppose that he gave much heed to his native Flora, except so far as he could find plants 


\section{In My Vicarage Garden}

good for food; but he did observe some of the native plants, enough at least to name them, for we still have plant names which are genuine old English, not Roman or Saxon. But if he did observe them at all, he would still find them now, for I believe there is not a single plant that has been completely lost to the British Flora. We hear, indeed, much complaining of the wholesale extirpation of plants ruthlessly dug up for sale, but though such extirpation is very grievous to those who suffer from it, it is confined to a few spots, and the plant as a British species is not lost. The beautiful Cypripedium Calceolus can only be found in very few spots, perhaps only in one, but it never can have been abundant; never sufficiently abundant to make any perceptible effect on the colour or vegetation of its native habitats. It is a most difficult thing entirely to extirpate a truly native plant anywhere; it is almost an impossibility. Nature is very bountiful, and if at any time appearances point to destruction, she is reserving her powers to bring in life again. The appearance and disappearance of flowers is one of the mysteries of plant life. Every collector knows that in some years he will find in fair abundance a plant that he has long looked for in vain; he finds it one year, and then perhaps it is many years before he sees it again. And I feel sure that none of the wild plants which grew in England in A.D. Ioo have entirely disappeared; they have, of course, been expelled from some 


\section{The Flora of England}

places by the growth of towns, and by cultivation, but that is all; they still carry on the battle of life elsewhere. But if the flora of ancient Britain still exists, it has been largely increased. If we go to any good British Flora, such as Hooker's or Babington's, we shall find so many species marked as aliens or introductions, that though I have not counted them, I feel sure that I am right in saying that at least one-eighth or more of the plants which now fairly find a place in British Floras are not really indigenous. These strangers have come to us in many ways. Many are garden escapes, some come from the ballast heaps on the sea coast, some may have been brought by birds, who are everywhere great distributors of seeds, and some, as on the West Coast of Ireland, are waifs from the Atlantic. Without going minutely into these, I will mention a very few conspicuous strangers, to show how our Flora is gradually being enriched. The great evening primrose of the coast of Lancashire is undoubtedly a garden escape, and so is the sweetscented coltsfoot, so valuable as one of our earliest spring flowers. The lily of the valley is a very doubtful native, while the snowdrop is certainly a foreigner, and where found apparently wild is probably a survivor from some old mediæval garden. And I have always felt certain that the white water lily is not a true British native south of the Trent, though a true native in Scotland. My proof is only negative, but I cannot fancy 


\section{In My Vicarage Garden}

that such a flower could have escaped the notice of all our old writers. How could Shakespeare have missed it, if it was as abundant in his time in Warwickshire as it is now? He must have named it, if he had ever seen it in rivers, as one of Ophelia's flowers, or even as one that

"Pulled the poor wretch from her melodious lay To muddy death."

Or how could Isaak Walton have overlooked it when he was writing so lovingly of rivers and of everything that lived in them ?

I come back to the question with which I started. What difference would a Briton who lived in A.D. 100 find in the natural scenery of England if he could re-visit it? He would find many differences, at first sight a great many ; but a closer view would show him that though there were many additions, the Britain of the nineteenth century was not so very unlike the Britain of the first, and he would soon recognise many wellknown and familiar features in the scenery, the animals, and the plants. How would it be with the inhabitants? Would he recognise as his family descendants the Englishmen of the present day, changed as they must have been by admixture with Roman, Danish, Saxon, and Norman parents? I think with a little trouble he might. And to go deeper still, would he recognise in the present moral character of Englishmen any re- 


\section{The Flora of England}

semblance to the character of his own brethren, and relations, and neighbours among whom he lived ? To that I cannot answer. I would rather take refuge in Horatio's evasive answer to Hamlet : "'Twere to consider too curiously to consider so." 



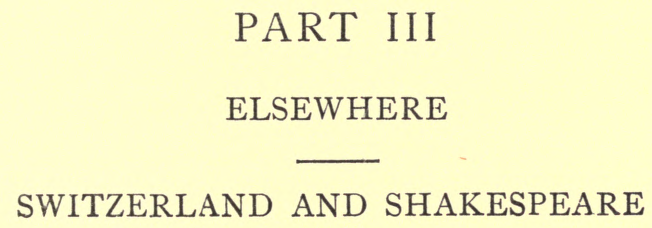





\section{CHAPTER XVIII}

\section{IN WILD SWISS GARDENS}

I HAVE been for a short three weeks in the Bernese Oberland, dividing the time between Thun, St Beattenberg, Grindelwald, and Mürren. Of these places and the glorious scenery I shall say nothing; it is of the flowers that I wish to speak, and with a special object.

Before I left England I was told by many friends that September was much too late for the Alpine flowers; but I did not fully believe this, for I had had a former pleasant experience that there was much to see and admire in the Alpine flora of August, and I felt sure that I should not find September all barren. Of course, I did not expect to see the flowers of May and June; I could not hope for primulas, or even for some of the gentians; but I went in the full faith that there was a goodly autumnal flora, and I have not been disappointed.

As soon as we entered the Jura and had left the dreary plain of France behind us, we were at once greeted by Astrantia major and the rich blue flowers of Mulgedium Alpinum, both growing close to the railway, and as we got amongst M 


\section{In My Vicarage Garden}

the true Alpine pastures it was clear from their colours that they held many flowers. The first true Alpines that we gathered were on our first walk from Thun to St Beattenberg. On the banks of the lake were the elegant Anthericum ramosum in fair abundance and in full flower, and the pretty little Saxifage, S. aizoides, chiefly the autumnal form with orange dots upon the yellow petals, a very handsome little flower and one very easily grown. This bright Saxifrage followed us everywhere; it was on the low grounds near Thun and Interlaken, it was high up even to the snow line, and on the moraine of the glacier of Gsalpenthorn, where the moraine is so shallow that in walking over it my alpenstock frequently struck the ice beneath, there was the Saxifrage with a few other plants, their roots actually touching the ice, and so showing that they loved the moisture more than they dreaded the cold. Through the wood between the Lake of Thun and St Beattenberg I found plenty of orchids past their flowering, and I only found one spike of tway blade; but I knew I should be too late for the orchids. The most abundant plant was the grass of Parnassus, which very much surprised me, for in England I do not remember to have seen it away from marshy and damp places; but in Switzerland it was everywhere, even in the driest places on the edges of precipices. I found it in such abundance all the way up from the Lake of Thun to the top of Gwennenalphorn (6770 feet) 


\section{In Wild Swiss Gardens}

that I am sure I could have picked specimens every yard of the way; our British Prunella vulgaris was almost as abundant, and equally careless whether it grew at a high or a low elevation. The monkshood also has a very wide range : on the lower levels it had evidently long past flowering, but on the higher elevations it was still abundant and very handsome. Just under the top of the Gwennenalphorn I came upon several circular pits, two or three yards wide and perhaps a yard across, caused, I suppose, by some natural subsidence of the soil ; these pits were filled with monkshood in full flower and of a very deep colour, and the circular shape of the pits crammed with the flowers gave them almost the appearance of artificial flower-beds. On the very top of the same Horn I found good flowering tufts of the lovely Saxifraga coesia; some good plants of Achillea moschata, also in flower; plenty of the pretty Astrantia minor, which I look at with envy, for I never succeeded in growing it, and I know of no one in England who has been really successful with it; while the very top was a thick bed of peat carpeted with Azalea procumbeus still carrying a few flowers. Very near the top I found a few good bunches of the Alpen rose, a shrub that always interests me, because, as far as I know, it is the only hardy rhododendron, except $R$. Davuricum (probably only a geographical variety), which will grow in calcareous soil. I have old plants in my Gloucestershire garden, 


\section{In My Vicarage Garden}

which in some years flower well; but though quite hardy it is rather capricious in its flowering. In the flowering season the Alpenrose must be quite the glory of the Oberland, for it seems to be everywhere and to be most luxuriant. In a walk from the little Scheidegg (6788 feet) I must have passed hundreds of acres of it, growing so thickly that I should think it impossible for anything else to grow with it, and, apparently, neither cattle, sheep, nor goats browse on it. Near the same horn (Gwennenalphorn) I was pleased to meet with a few flowers of the Gentiana Bavarica and some plants of the pretty pink umbellifer, Pimpinella rubra, at that height a compact plant, and well worth growing in the garden if it would keep that habit. Of course, there were many plants not in flower, but which it was pleasant to see and recognise, such as Primula auricula, $P$. viscosa, $P$. farinosa, and probably others, Soldanella in abundance, Tussilayo alpina, Maiantheum bifolium, Saxifraga rotundifolia, etc.; but I was surprised at the almost entire absence of the sempervivums and sedums. I had hoped to see plenty of the cobweb sempervivum, which is almost as beautiful without its red flower; but I only found a few specimens near Mürren, and not one of any other species, and their absence surprised me.

I have said that I did not expect to see many gentians; but I have seen more than I expected. Besides the $G$. Bavarica just mentioned, and of 


\section{In Wild Swiss Gardens}

which I found a few more flowers in other parts, the handsome $G$. asclepiadea was abundant in many places, and at its best; and, in a wood on the slopes of the Mettenberg, I met with a very beautiful variety, in which all the leaves were in the same plane, with the flowers on one side only of the flower-stem (technically secund), and of the most delicate pale-blue colour. Close to the upper glacier, between the Wetterhorn and the Mettenberg, I came upon a complete bed of the G. ciliata in full bloom, and I think this almost the most beautiful of the dwarf gentians. Its colour is a deep sapphire, as rich as in $G$. verna, but each petal has a fringe of hairs, from which it gets its specific name, and which adds largely to its beauty. There was in many places an abundance of the annual $G$. Germanica, but its dull colour makes it the least attractive of the gentians. Near the Grindelwald glaciers the ground was in many places quite carpeted with the Dryas octopetala, but the season for flowering had long past; I saw, however, some in good flower near the lower glacier, and still more almost close to the ice of the Gsalpenthorn glacier, and a good many on the high ground near the little Scheidegg, where I also found a wonderful specimen of "English as she is spoke." On a large official board outside the Scheidegg station was a notice in German and English, the English being: "Here is gratis to see the oldest Miss of the world"-i.e. the Jungfrau. 


\section{In My Vicarage Garden}

I said that the pastures showed by their colours that the time for flowers was not yet over. The prevailing colours were blue and pink, the blue given by a campanula, and the pink by a colchicum. The campanula ( $C$. Scheuzeri) is very like our harebell, but it has rather larger flowers, which are nodding and not upright, and it has not the round radical leaves which give ours its specific name ( $C$. rotundifolia), and so is botanically distinct. The pink colchicum is slightly different from our British plant, and is $C$. Alpinum, and it is everywhere in the pastures, and its abundance in them puzzles me. In England the colchicum, or meadow saffron, is considered almost poisonous to cattle, yet in Switzerland, where the pastures are being mowed all the year round, the cattle must eat it in every stage. It is a favourite flower for visitors to pick; they bring in large bunches, which soon fade, and they call them crocuses, but it is not a crocus, and differs in many ways which I need not state particularly; and, according to the Swiss botanist, Dalla-Torre, there is no native crocus in Switzerland. But in nothing does the crocus more differ from the Colchicum than in its medical qualities. No crocus is hurtful, and as the producer of saffron the crocus ranks among the wholesome plants; while the poisonous character of the Colchicum may be gathered from the fact that its near botanical ally is the black Hellebore, or Veratrum, from which the strong narcotic poison, Veratrine, is extracted. 


\section{In Wild Swiss Gardens}

When the large leaves, carrying with them the triangular fruit, appear in the spring, this relationship is more apparent ; in the autumn the pretty flowers look innocent enough, and are a great ornament in the pastures. There is a little external interest attaching to the Colchicum, for its selection by Paley in his Natural Theology as a striking instance of design. I have not the book at hand to refer to, and it is of little consequence, as I am sure there is not a plant that grows from which the same lesson could not be taught. One other plant of the pastures must be mentioned, though it was almost out of flower, a stately yellow thistle ( $C$. spinosissimus), standing about a yard high, which seemed succulent and not out of place in the pastures.

If September is a little too late for an abundance of the wild flowers of Switzerland, we can at least find the flowers turned to fruit, and in many cases the fruits are very beautiful. I found wild strawberries, raspberries, and wortleberries, but not in abundance ; the bright red berries of the bearberry were everywhere, but I have seen bushes better covered in Scotland; the red-fruited elder does not seem to be as abundant in the Oberland as in other parts, and I only found one grand bush in fruit near Mürren; but its place was well supplied by the scarlet fruits of the barberry, which were in great beauty; but the bushes seemed to be much smaller than our English bushes. But there were two plants in seed which were the admiration of 


\section{In My Vicarage Garden}

everybody. One I saw only in the wood through which the queer funicular railway runs from Lauterbrunnen to Mürren, and it had the appearance of long sprays of delicate white feathers covering a largish tract amongst the bushes. They were most beautiful, yet they were only our large willow-herb in seed. It is not uncommon in England, and abounds in some of the valleys of the Cotswold, but I never saw it in such a beautiful state before, though I am told it is as beautiful in some parts of Surrey. The other plant was the dwarf thistle ( $C$. acaulis), which when in flower is simply a purple dwarf thistle of no special beauty, but when the flower is over it is most beautiful. The involucre lies flat upon the grass, a bright, many-rayed star (three or four inches in diameter), with a sheen like burnished silver, and I was not surprised to see that many visitors, especially ladies, picked it in quantity and admired it, though only a thistle. It is often compared to the Edelweiss, but in my eyes it is far more beautiful, for I could never very much admire the Edelweiss, which has always seemed to me something of an impostor that has won for itself a high reputation under false pretences. Its chief claim was the sentimental one that it was so difficult to find that each Swiss youth risked his life to find it and present it to his sweetheart as a proof of his manly prowess; it is now known to grow in many places where any boy or girl can reach it I 84 


\section{In Wild Swiss Gardens}

without difficulty. Then it was said to be impossible to grow it away from its native mountains; it is now found to be easily grown in England, if raised from seed. It is claimed, too, to be a flower of supreme beauty; but the white star, which forms its chief attraction, is not a flower at all, but the involucre which surrounds a number of small insignificant flowers, and it is not a pure white, but in colour, as in texture, it looks like a piece of rather dirty white felt. So, altogether, I prefer the dwarf thistle in seed; and if anyone will take the trouble to pull this to pieces and examine it under a moderate lens he will see that each pappus is a lovely little parachute, of which each hair is a perfect feather of the finest silk. And before leaving the fruits I must mention one more which much interested me, our groomwell (Lithospermum), which I found in some of the woods in great abundance. The interest lay in this, that much of the shagreen from which our grandmothers' spectacle and etui cases were made was a manufactured article from asses' skin, into which were pressed hard seeds chiefly of the Lithospermum. As this is rather a rare plant in England, I never could understand where the supply of seeds came from; but now having seen it in such abundance in the woods of Switzerland, I can well fancy that the supply may have come from thence.

I need not say anything about the ferns; their beauty is to a large extent independent of the 185 


\section{In My Vicarage Garden}

season, and their beauty, variety, and abundance are as great in the autumn as in the summer. Nor do I say anything about the cultivated gardens. The Swiss cottager cares little for a flower-garden; his energies are all spent on vegetables, and his vegetable-garden is generally untidy and ill kept. The only place in which he shows a love for flowers is in his window-gardening, and sometimes this is done very well indeed. I saw in a chalet window near Meringen two large pots of Portulacca which would have won a prize at a London flower show; they were beautiful in themselves, and excellent specimens of good cultivation. But of home gardens I have seen little to admire except at some of the great hotels - at Interlaken especially, but also at Thun. These were really fine specimens of good gardening, and show what could be done in that climate with very little care; the immense bushes of geraniums of all sorts and of Althaa hibiscus were quite magnificent.

There were many other good flowers and fruits besides the few I have named; but even if I named them all I could not, and I do not mean to, say that the Alpine flora of September will bear any comparison with that of June and July. Many of the plants have long past flowering, and of those that remain a large number are also British plants. But my point is that if any lover of plants, and especially of Alpines, should be prevented from going to Switzerland earlier in the I 86 


\section{In Wild Swiss Gardens}

year, he need not give it up altogether under the idea that he will see nothing to repay him for his long journey. He will see a great deal. The grand features of the country; the everlasting hills changing every day and almost every hour, and yet always the same; the mighty precipices; the deeply interesting glaciers; the lovely slopes, rocky or grassy, leading down to blue lakes or green valleys; the sweet woods and the waterfalls-all these will be as good to him in September as in June. And if he has an eye for plants, and a love for them, with just sufficient botanical knowledge to know something of them, even when their flowers are gone and perhaps even when past their seed-time, I can assure him that in every walk he will find something new, something that he has not seen in England, and something that will interest him at the time, and bring pleasant memories to him in days to come. In his walks he will find the alpenstock a very efficient help in taking up plants, and especially in dislodging them from places a little beyond his reach; and I can strongly recommend to him, as a pocket companion, The Tourists' Guide to the Flora of the Alps, written in German by Professor DellaTorre, but translated by Dr Bennett, and sold in London. It is most trustworthy, and its only fault is that it is too concise. It is purposely so, in order to reduce the size; but rather longer descriptions would be welcome, even at the cost of a slight increase in size. 


\section{In My Vicarage Garden}

In one point only-I cannot quite pass it bythe Bernese Oberland is not altogether pleasant to the English Churchman. I was there three Sundays - one at Thun, one at Grindelwald, and one at Mürren, and in all three, neither the buildings or the services are what might be expected from the hundreds of English visitors who come there every year. In this dearth of proper buildings it is a comfort to feel that the whole country is one grand temple in which is preached with no uncertain sound the majesty and the goodness of Him, Whose we are, and Whom we serve. "Altitudines montium Ipsius sunt" is the feeling that can never long be absent from us, and the many references to the hills and mountains and the lessons they teach which abound in the Psalms and the Prophets come back to us with new force and value. Yet the "hills which stand round about Jerusalem" are as rothing compared to the mountains of Switzerland ; even the glory of Lebanon, the Mont Blanc of Syria, though a snow mountain, is little more than half the height of the Mont Blanc of Switzerland, and no Jewish Prophet or Psalmist could have seen or known anything of the wonderful mysteries of the glaciers; they had passed away from Lebanon and Syria long before the day of Prophet or Psalmist, but we know that they were there once, for the cedars of Lebanon now grow on an ancient glacial moraine. 


\section{CHAPTER XIX}

PIORA

IF any readers of the Guardian are in search of a place in Switzerland where they will find quiet rest in the midst of beautiful scenery and abundance of flowers I would recommend them to go to Piora. It is very easily reached. If they are in a hurry they can go from Luzern to Airolo in less than four hours; but if they can spare the time they would be well repaid if they took the route from Luzern to Fluellen and Goschenen, then by omnibus to Hospenthal and walk over the St Gothard Pass. This is a walk that is now very seldom taken, but it is a grand walk and an easy one; and though the two miles on each side of the Hospice are barren and desolate, there is not a yard of the road without some object of interest. The road itself and the Simplon are the finest pieces of road-engineering in Europe, and it is kept in beautiful order, though the traffic must now be very largely diminished since the opening of the St Gothard Tunnel. The view on the southern descent when we first look into the Val Tremola is a view that none will forget when once seen. The long road made in a succession of corkscrew turns has quite a weird 


\section{In My Vicarage Garden}

look, and seems as if a giant had amused himself by making gigantic flourishes on the rocks. But the result of the flourishes is that the walker finds the descent very easy; he has a good road under him, a brawling and beautiful stream-the Ticino -by his side all the way, with grand rocks and good plants. It is not, however, a walk to be undertaken too early in the season; it was the first week in July when I took it, and in many places the road was cut through deep snow; the pretty little Lac Lucendro was unapproachable, and the lake itself frozen over and covered with snow, and the Ticino in many places completely bridged over with snow for considerable distances. The corkscrews of the road are carried on almost into Airolo, but near Airolo they are of greater length, and the short cuts can be taken with safety and ease. At Airolo there is more than one good hotel, but any one who wishes to go to Piora would do well to go to the Hôtel Lombardi, as the landlord, M. Lombardi, is the landlord of the hotel at Piora, as he is also of the hotel at the top of the St Gothard Pass. The ascent to Piora is not for wheels of any sort. Very soon after leaving Airolo we commence to mount by a good mule path, and for the first half of the way the path is not at all steep; but after passing the little villages of Madrano and Brugnasco we reach Altanca, where the ascent begins to be steep, and in some places a little scrambly, but very delightful as it goes by a succession of zigzags parallel 


\section{Piora}

with the pretty stream of the Fossbach, which descends rapidly and in a succession of grand waterfalls from Lac Rhitom into the Ticino. The finest of the waterfalls is close to Piora, and the lover of good flowers will be delighted to see the two steep sides of the gorge studded with white patches, which are the flowering spikes of the finest of all Alpine saxifrages, $S$. cotyledon, that seems only to reach its fullest beauty where it can find bare rocks within reach of the spray of a waterfall. The mount from Airolo took me a little under four hours; a good walker would do it in half-an-hour less, or even an hour less, if he was walking against time, which I was not. Ladies are sometimes taken up on horses or a chaise à porteur; but the walk is quite practicable for ladies, and I found no real difficulty in the walk up or down, though I confess to having been glad when the walk came to its end.

The Hôtel Piora is placed at the very edge of the lake; it is the only house in the neighbourhood, and it is a small hotel, so that those who wish to go there must order their rooms some days beforehand. But when once there the visitor will soon find that it is a place to stay in, and will not be in a hurry to go from it, unless, perhaps, the weather is very bad; and, though I only experienced it for one day, I believe that on many days the place is clouded with mist, sometimes for days together. I would gladly have 


\section{In My Vicarage Garden}

stayed longer, and will now tell what reasons I have for recommending the place.

I said that I should recommend it to those who are in search of quiet rest. It is not suited for those who want to get in the midst of Alpine scenery large tables d'hôte, picnics, and full-dress promenades; they will find what they want better at Luzern or Interlaken. But for those who, like myself, wished for quiet and rest but not solitude, I can imagine no place that will better suit their wishes. The hotel is a small one, and during the week I was there I suppose we were never above twenty; but that is not all. While I was there the company that I met was not only a small company, but to me a very pleasant and very sociable one. Of course, there was the inevitable bride and bridegroom on their wedding tour, who kept themselves apart, but I always rather like their company if there are not too many of them ; and I like to watch them as far as I can do so without distressing them. The watching may have in it some regret for the days that are no more; but it is a pleasure to see two young people so thoroughly all in all to each other, that mountains and flowers are very small items in their happiness; and it is pleasant to think that to them, too, the mountains and flowers are teachers, and that the time is not far off when to them Piora and such like places will be a delightful memory that will beckon them back again; and then, coming with fuller years and larger 


\section{Piora}

interests, the mountains and flowers will give a happiness and teach them many a delightful lesson which they could not see or listen to before. But these formed a very small portion of the company; the rest were all gentlemen and ladies, each with some favourite pursuit carried out in almost a serious way, yet not so serious as to shut out the idea that they were all taking a wellearned holiday, and having a perhaps needed rest. Most were flower-lovers, perhaps all were more or less; and some had a real knowledge of plants ; others were geologists and crystal-hunters; all seemed to have some steady, sensible pursuit, and all seemed to be glad to contribute of their knowledge to the rest. Whatever flower I brought in and could not name, I had no difficulty in getting its name from someone else, and I never got from any the slightest idea that I was troubling them with my questions. In that way the place was to me an ideal place for rest and recruiting; while each went his or her own way on their pursuit they were all ready to help and take interest in the pursuits of others. I may have been exceptionally lucky in the company I met, but I am told that the company at Piora always consists rather largely of scientists, who find there a good field of research.

Another point which to me is a strong recommendation of Piora is that all the walks are within easy distance of the hotel-in fact, they are for the most part close--so that it is not $\mathrm{N}$ 


\section{In My Vicarage Garden}

necessary to walk three or four miles before you come to the object of your walk. The lake is surrounded by fine mountain peaks, each of which will give a good walk. The ascent of Taneda $(8760 \mathrm{ft}$.$) will require the best part of a whole$ day, especially if, as it generally is early in July, the route is blocked in many places by deep snow; and there are many other good points which will require all the time between breakfast and dinner. But for those who do not wish for, or cannot take, such long walks, there are many delightful excursions close at hand. The Fongio rises from the very walls of the hotel, and you may do as much or as little of it as you like; each step is varied both in flowers and view. Within a hundred yards of the hotel door you may be among alpines that will delight any lover of such plants; and you may with ease go on to the top ( $7257 \mathrm{ft}$.), and at each turning in the path the view and the plants will change ; or you may come down after having made half of the ascent wellsatisfied with your walk. I think one of the pleasantest walks I took was all round the lake, making a walk little over three miles. As you look on the lake from the hotel windows, you see, as it is usual in most Alpine lakes, that the south side with a northern aspect is well clothed with trees and bushes, while the north side with a southern aspect is apparently bare and barren-but it is only apparently so; both sides are well supplied with flowers, but of a different 


\section{Piora}

sort. I walked first along the low ground of the south side (northern aspect); it had an undergrowth of Alpine rose with a thin wood of scattered firs; and among this undergrowth was a rich growth of flowers, many of tall growth such as Veratrum, the taller gentians, and monkshood. The top of the lake was a marshy meadow formed in the silt from the mountains, with two small streams. One of these I had to wade, and found the barefooted walking so pleasant that I continued through the rest of the marshy meadow, and made a discovery which I had not noticed before. The river that I waded was icy cold; the grasses and sedges were pleasant but a little rough; but the masses of sphagnum were very pleasant, and perceptibly warm to the feet. This warmth of the sphagnum is a puzzle which I cannot solve. I can only suppose that the hot sun warms the water in the sphagnum, and that it does not readily part with the heat so gained. The marshy meadow was full of good marsh plants. The walk home was along the north side (south aspect) which looks entirely bare and barren; yet every foot has its good flowers, but all of a low growth. I think this ease of reaching good points both for views and plants is a very great recommendation to Piora.

But it is time to come to the flowers; and in speaking of them I feel almost compelled to speak in what might well be called exaggeration and a too great use of superlatives; but it is really 


\section{In My Vicarage Garden}

impossible to speak of the flowers of Piora without using superlatives and what seems like exaggeration. Before I left England I had been told by more than one friend well versed in flowers generally, and especially in Alpine flowers, that in no part should I find such a paradise of flowers as at Piora. So I went in faith, and they really far exceeded my wildest expectations. I took with me Gremli's Swiss Flora for Tourists, published in English by Nutt, in the Strand--a most excellent little book which I can strongly recommend to all who go to Switzerland in search of flowers. I can also recommend, but not so highly, Correvon's Flore Coloriée de Poche, published in Paris. It has some fairly good plates, which are helpful, but it only records the more conspicuous flowers, and is not exhaustive as Gremli's is. Now Gremli describes 2637 Swiss plants, including ferns and grasses, but without the mosses, fungi, and lichens, which of themselves must be a study; and I feel quite sure that within a radius of three miles or less from the hotel it would be quite possible for a good searcher to find more that one-half of these 2637 plants. I was not searching for plants; I simply admired and gathered those that were near the paths in my walks; and yet the number of different plants that I saw-many of them seen wild for the first time-were a constant delight, and a delight that was varied every day and in every walk. It was not only the large number of species, vut it was the large number of the inI 96 


\section{Piora}

dividuals of many species that was to me so remarkable and noteworthy. I will name a few. The Gentiana acaulis was a little past its best, but it was abundant; and I am not exaggerating when I say that during the week I was there I must have walked over acres of the gem-like $G$. Bavarica. I had no idea that I could anywhere see it in such masses; and it seemed to be in no way particular as to its position; it was abundant, and perhaps most abundant, in the damp ground near the lakes, but it was also in many high places. The whole place was especially rich in gentians; besides the G. acaulis and Bavarica, there was $G$. lutea, cruciata, punctata, asclepiadea (not yet in flower), and Germanica. This last one I was especially pleased to see; it is a British plant, and I know it well, especially on the Cotswolds. But there is a great difference between the British and the Swiss plants, and it is a difference which shows how largely the colour of flowers is affected by their soil, situation, and especially, perhaps, their elevation. In England the flower is a pale blue: at Piora the colour is all brilliant as that of G. Bavarica, which it so much resembles at first sight, that it is not till you take the plant in your hands and see that it has an annual root, and that it has many flowers in its little stem instead of the one flower that $G$. Bavarica carries, that you see the difference. As with $G$. Bavarica, so it was also with the bird's-eye primrose ( $P$. farinosa). It was 


\section{In My Vicarage Garden}

everywhere in hundreds, and you could not help treading on the little beauty. I do not think it was finer than I have seen it at Malham and Ingleborough in Yorkshire; but I saw many specimens of a far richer and deeper colour than I have seen in England. The Alpine rose was everywhere, and was in its fullest beauty at that high elevation, though near Hospenthal it was almost past flowering. I delight in the alpenrose, not only for its bright flowers, which give such a colour to so many Swiss hillsides, but because it is the only rhododendron (except $R$. Dahuricum, which some consider only a geographical variety) that will grow on soil charged with lime. To me the faint smell is rather pleasant, though to some it is quite unpleasant; and at Piora I learned two facts about it which I had not noted before. There is everywhere wet, marshy ground on the hillsides, not bad enough to stop a walker, but enough to make his feet damp. I noticed that wherever I could see an Alpenrose the walking was good and firm, though it may have appeared to be growing in a marsh. The other thing I learnt about it was that it gives most valuable protection to many plants. I suppose it is not grazed by cattle, sheep, or goats, and the result is that many good plants come up right in the midst of the bushes, and, I suppose, protected by them. I found many grand specimens of Aquilegia alpina so growing; also Streptopus amplexicaulis and others; and nestling round the outside 


\section{Piora}

of the bushes, and well protected by them, I found Maianthemum bifolium, Pyrola rotundifolia, and other gems. And I think it was worth all the journey to Piora if only to see the St Bruno's lily (Paradisia liliastrum) in flowers. The first flowers were showing themselves when I was there; but I am told that when in full flower the hillsides are white with them, and that they can be gathered in sheaves. I have grown it for many years and admired it, but I never realised its supreme beauty till I saw it on its native hillsides. There surely can be no flower more thoroughly beautiful, while the whiteness of the flowers is the nearest approach to absolute purity that can be conceived. I shall never forget it as I saw it first at Piora. Growing with the St Bruno's lily, and in many other places, was a large quantity of the fine yellow Alpine anemone (A. sulphurea), which I had seen before in its full beauty on the Furka Pass, where one hillside was so covered with it that at a considerable distance the whole hillside looked yellow; but at Piora the time of flowering was past yet the beauty was not gone, for the heads with their many-feathered seeds were very beautiful.

It is very tempting to say more of the many beautiful flowers that I saw, but time and space would fail me; but there is one plant that I must on no account pass by. The Cobweb Sempervivum (S. arachnoideum) is everywhere, clinging to chinks in the rocks, and of wonderful beauty; there were 


\section{In My Vicarage Garden}

many small patches of it which I could only compare to brooches set with brilliant jewels; the outside of each rosette being a pale rose, and the inside a glittering spot formed by the cobweb that joins together every leaflet of each rosette. This likeness is increased by the fact that on all that I saw at Piora the rosettes were very small, and unopened except to a small extent. I fancy that later in the year the rosettes expand and become flat, but they are so closely packed that it is hard to see how they can find room to expand. I was none the less glad to see the little beauty growing in such abundance and beauty, because I have never thoroughly succeeded in growing it. In England it is a most capricious plant, growing well in one garden, and in another, with apparently the same surroundings, utterly refusing to live. And I must add another charm that the flowers give to the walks at Piora-there is an abundance of sweet-scented flowers. Among these there are two small orchids of very delicate and pleasant smell, the little black orchid, nigritella angustifolia, and the gymnadenia odoratissima; the nigritella being fairly abundant and the gymnadenia not so frequently met with. These, however, do not give out their scent till sought for, and so do not account for the pleasant smells that are met with in the walks unsought. Much of this comes from the Alpenrose, and after rain the sweetbriar bushes scattered through the woods give out their well-known scent; but there are 


\section{Piora}

two low-growing plants which, as I think, fully account for the pleasant scents. The one is our own thyme, which is everywhere, but I think the chief scent is given out by the pretty Alpine milfoil, Achillea moschata; it is very abundant, and when crushed gives an aromatic musky smell.

For plant-collectors, as distinguished from plantlovers, Piora is a delightful place. I was not collecting plants; I was simply looking for them to see them in their native habitats and to admire them in their native beauty. But I wished I could have collected the native plants and taken them home, for I do not remember ever to have seen a place in which they could be collected so easily and with such almost certainty of success. The lower parts of the hills, which alone I examined, are composed of débris formed from the stones that have come down from the rocks above, and are covered with and permeated throughout by a rich humus, which is practically all decayed leaf-mould. The stones are none of a large size, and it is very easy to remove them; with a little help from the alpenstock they can one by one be removed, and then the root, though often penetrating the humus to a great distance, remains exposed, and the whole plant can be taken without injury. And at Piora there is little fear of the most greedy collector doing any real destruction; he may help himself as largely as he likes with a very clear conscience, and he will do little 


\section{In My Vicarage Garden}

harm for those who come after him. As an instance of the ease of taking up difficult plants there, I may say that the evening before I went away I wished to find some seedlings of the handsome Gentiana punctata which I had marked by the lake side not far from the hotel, for I knew that a full-grown $G$. punctata has a big root which it is almost hopeless to attempt to dig up with any chance of success. I soon found the plants, and among them many little ones that seemed exactly what I wanted. But I also found they were no seedlings; the little bunch of radical leaves concealed a root stock more than an inch in diameter, and it took several minutes of work with the alpenstock to follow the root to the end, and then it turned out to be nearly a yard in length, with many ramifications, but the nature of the soil allowed me to get all I wanted without any injury to the roots. All collectors should remember that it is of the first importance not to bruise or break any of the roots; if they are bruised or broken, nature's first work is to heal the wounds, and while so doing little other work is done to the life of the plant; and if they are badly bruised and are long out of the ground and so get dried, death is almost certain. Collectors should also remember that it is labour in vain with a great many plants to take them from a soil of one marked character and transplant them into another. All the plants at Piora grow in the débris of primary rocks at a high 


\section{Piora}

elevation; many of them, like the rhododendron, will grow anywhere, but a very large number, the majority perhaps, will simply die when removed to a soil composed of lime or chalk at a low elevation. I feel sure that the mountain air is a great factor in the vigour and abundance of Alpine plants, and in many instances in the colour of the flowers, and cannot help thinking also that the reduced atmospheric pressure which the flowers get at high altitudes has its influence upon their healthy growth.

I have, I think, said enough of the flowers of Piora, but before leaving my account of its many attractions I ought not to forget to mention the very reasonable charges at the hotel; the charge en pension was eight francs a day.

In so small an hotel there is of course no chaplain, and there is none nearer than Airolo; but I cannot altogether consider that a drawback to the place; I would far rather be a priest unto myself on one of the beautiful hillsides than be condemned to one of the dreary Puritanical services in unworthy buildings which are so common throughout Switzerland, and advertised as "English Church services."

I have no doubt Piora is a very healthy place, and would be a good place for a long stay, but I fancy a little acclimatisation would be necessary for some people before they got the full benefit. I heard of several instances where the visitors had not been quite well after the first day or two. 


\section{In My Vicarage Garden}

Perhaps the snow-water-the only drinking water in the early part of the year-may partly account for this; but I am sure that a sudden change from such an elevation as the valley of the Ticino to the elevation of Piora does not suit everyone at first. I went on the same day from Piora to Lugano, walking to Airolo and by train to Lugano. When I left Piora my aneroid marked below 24 degrees; when I got to Lugano it marked above 28 degrees. This sudden alteration is certainly rather trying to elderly people, or to those not in full health; to the growing and strong it would make little or no difference; but I mention it because I think it would be wise for some to take it into account.

I hope I have now proved that Piora is a place of which many would be glad to know. I have wished to show that it has many requisites for a holiday resort in Switzerland. It is easy of accessCuivis contingat adire Pioram - and when there the visitor has quiet rest, with beautiful scenery, lovely and easy walks, and an abundance of the choicest flowers of the Alps. I will only add a few words on a matter partially connected with my subject, though not much. I am not a cyclist, but I can scarcely imagine a more beautiful ride for a cyclist than the road from Luzern or Weggis to Airolo. The roads are throughout most excellent, the gradients everywhere easy, and in most parts very easy, though the ascents are great, and the scenery throughout of the very finest description and vary- 


\section{Piora}

ing in every mile. If when the cyclist gets in Airolo he is induced, by what I have said, to visit Piora, he must, of course, leave bicycle at Airolo and take to his legs; but when he comes down he may well go on a little further through the valley of the Ticino. The valley is very beautiful with the Ticino all the way; about half-way down he will be amongst the maize and vines, and at the end he will find all he can wish for at Lugano and its beautiful lake. But I must say nothing more about this-my one subject is Piora. 


\section{CHAPTER XX}

\section{SHAKESPEARE AND ARCHITECTURE ${ }^{1}$}

SHAKESPEARE was a wonderfully many-sided man; and many books have been written to show his intimate knowledge of almost every science or craft, a knowledge in some instances so minute as to lead to the conclusion that he must have passed his life, or a large part of it, in that particular business or profession. A good list, but not a complete one, of such books may be found in Professor Bayne's masterly biography of Shakespeare in the Encyclopadia Britannica. But because he has written more or less on every subject, and has shown his knowledge in almost every art, science, and handicraft, we feel that there must have been a good reason when he entirely omits some subject on which we should like to have had his opinion, and which we feel sure must have passed under his notice. But

${ }^{1}$ Some of my readers may see no connection between this chapter and the foregoing chapters on flowers. There may not be much, but I publish it, partly on the advice of others whose judgment weighs much with me, and partly because to me flowers and Shakespeare are closely united. I tried to show this in my little book on the "Plant-Love of Shakespeare," and every day I feel that the two are my very close companions and friends, and as such I find it hard to say which I value most. 


\section{Shakespeare and Architecture}

there are such omissions, some of them very noteworthy, and they help us to some small extent to find out what he really was, by showing us, though in very small measure, what he was not.

Two of these omissions are very curious, and have been often noticed. The first is that he is almost silent upon dogs, except for their hunting qualities, and in the few places in which a dog is mentioned, it is in terms of contempt; and of the dog as the faithful companion of man there is no mention at all. There is a well-known story, originally told by Sir Henry Holland, and repeated by Miss Phipson in her Animal Lore of Shakespeare's Time, that-

"Lord Nugent, the greatest Shakespearian scholar of his day, declared that no passage was to be found in Shakespeare commending, directly or indirectly, the moral qualities of the dog. A bet of a guinea was made, which Sir Henry, after a year's search, paid."

The other curious omission is tobacco. In Shakespeare's time the use of tobacco was necessarily much less than at present, but it was perhaps more celebrated by writers of the day on account of its recent introduction, and no limits were placed to its medicinal powers. It was almost considered a remedy for every evil under the sun; it was the herba sancta, herba diva of the botanical and medical writers, the "divine herb" of Spenser, and Gerard has two pages full of its "vertues," ending with recom- 


\section{In My Vicarage Garden}

mending it to all "courteous gentlewomen." Yet Shakespeare never mentions or in any way alludes to it. He must have been well acquainted with it; no man in his day could have escaped seeing it frequently, "and some cannot forbeare it, no, not in the midst of their dinner," says Gerard. And as a constant companion of Ben Jonson, who was a great smoker, he must often have taken his part in smoking parties, or at least in parties where smoking was carried on. But he has not a word, good or bad, to say about it ; and Mr Stacy Marks tells us in his Pen and Pencil Sketches that when he presented a cigar and cigarette box to the Royal Academy he searched in vain for a Shakespearian motto, and was at last obliged to content himself with twisting to his purpose Othello's passionate address to the sleeping Desdemona :-

$$
\text { "O thou weed, }
$$

That art so lovely, fair, and smell'st so sweet."

But besides these two omissions, which are well known and have been often noticed, there is another which, as far as I know, has not been noticed, but which seems to me very remarkable. On the arts generally he has much to say, and says it as one who had a warm appreciation for art. In music, both vocal and instrumental, he must have been a proficient; his writings are full of good allusions to music and musical terms well applied; they are, indeed, so full that I have 208 


\section{Shakespeare and Architecture}

often wondered that no book has yet been written on "Shakespeare as a Musician"; it might be made a most interesting book, but it would have to be written by one who was a master of the art, and who knew much not only of modern music, but of old English music. He also evidently had some knowledge of painting; not so much as of music, but enough to show that good painting had an attraction for him, and that he knew something, though perhaps not much, of its technicalities, and that he had seen good and celebrated pictures. But while he can speak well, and even learnedly, on music and painting, he is almost silent on architecture of every description; here and there he is forced to say something about a building, but the architecture, however beautiful, seems to have had no attraction for him. Either he did not care for it, or he knew nothing about it; or he had some special reason for keeping silence on it. I think it worth while to go into this remarkable omission more minutely.

When we consider what the state of England was in Shakespeare's time in respect of fine buildings, it would seem almost an impossibility that any man who had a tithe of Shakespeare's powers of observation could have passed through the land and lived his life in it, and written largely on almost every subject, and yet take no notice of buildings which met his eye in every direction. Yet so it is. Take the castles of England. We 


\section{In My Vicarage Garden}

can have some faint idea of the abundance of grand castles in every part of England at the end of the sixteenth century from the few which remain to us entire, and from the far larger number which for us only exist as ruins. In Shakespeare's day they were still standing in all their strength, and in all their beauty; but what can we learn of them, or of the history of any of them, from his writings? Many castles are mentioned, and in many of the plays the scenes are laid in castles or their neighbourhood, and yet not one is described in such a way that it could be distinguished from others. He notices sometimes the surroundings of a castle, and describes the scenery in which it stands, but of the castle itself he says next to nothing. For many years of his life he lived within a very few miles of Warwick Castle, then, as now, remarkable for its great strength, and, from its unequalled position on the banks of the Avon, one of the most beautiful of English castles ; and in more than one of the plays the Earl of Warwick plays an important part, yet he tells us nothing of the castle. He probably had often seen Berkeley Castle, and he could tell of the "high wild hills and rough uneven ways" over the Cotswold that led to it; but he has nothing to tell us of the castle itself except its natural surroundings- "There stands the castle by yon tuft of trees." He also knew Windsor Castle and its surrounding forest, and he has laid many scenes there; but the only account that we get of the 


\section{Shakespeare and Architecture}

building is confined to the "several chairs of order" with "each fair instalment, coat and several crest with loyal blazon." We should not expect him to give us any description of Macbeth's Castle, though he had imagination enough to do so had he so wished, but as with Berkeley he picks out only its natural surroundings_- "This castle hath a pleasant seat, and this the-

\section{guest of summer}

The temple-haunting martlet does approve

By his loved masonry that the heaven's breath

Smells wooingly here."

The Tower of London must have been a familiar object to him on his way to and from the Globe Theatre, and many of his characters are made to play their sad parts there, but of what it was like he gives us no hint; it is "Julius Cæsar's illerected tower," and that is all. It is the same with all the castles mentioned, and they are many; they are simply spots on which he may place his scenes, and, great word-painter though he was, there is nothing but the name to distinguish one castle from another. It is the same with dwelling-houses of all sorts. In his time England had so far recovered from the Wars of the Roses that it was getting well covered with grand houses of all descriptions, no longer built as fortresses for protection, but for comfort and beauty. During his life many of the great mansions which we now call Elizabethan were built, and he must have 


\section{In My Vicarage Garden}

known many of them, and all the Royal palaces were being changed from dark fortresses to splendid and comfortable homes. But of all this great change we learn nothing from Shakespeare. Palaces are mentioned, and manor-houses, but merely mentioned; and the only descriptions we get are that one house was a "moated grange," and a clown talks foolishly of "bay windows transparent as barricadoes, and the clearstores towards the south north as lustrous as ebony"; and that is all.

The omission is still more marked in the case of ecclesiastical buildings. We can form some idea of the riches of England in ecclesiastical buildings in Shakespeare's time from what we still have either entire or in ruins. Every town of importance was crowded with fine churches; while many of them had grand cathedrals and abbeys, and in every parish there was at least one church, many of them such as we now almost despair of excelling, and all of them, if not so beautiful as his own church at Stratford, yet showing some architectural beauty which no Englishman could altogether have overlooked. But in the England of Shakespeare's plays these find no place. In one place only is Westminster spoken of and as a cathedral church. St Paul's magnificent cathedral, as it then was, is merely spoken of as "Paul's," and as a place of ill resort; a few abbeys are mentioned, but only named; and, though he must have passed through Oxford often on his way 


\section{Shakespeare and Architecture}

between Warwickshire and London, its architectural beauties had no charm for him; it is simply mentioned, with Ipswich, as one of the "twins of learning" raised by Wolsey, which "shall ever speak of his virtue." In one place it would have seemed that he must have spoken of the beauty of ecclesiastical architecture, if it had any charm for him; but he passed it by. The messengers sent to Delos in The Winter's Tale, when reporting the beauties of Delos, speak, according to Shakespeare's custom, of "the climate delicate, the air most sweet, fertile the isle," and they report "the celestial habits, and the reverence of the wearers," and the solemnity of the sacrifice; but all they report of the Temple is, "much surpassing the common praise it bears."

And if he is silent about English cathedrals, abbeys, and churches, he is equally silent about the solemn services which were carried on in them. He was a religious man, and certainly no Puritan; but there is little or nothing to show that he had any respect for solemn religious services, or that they formed any part of his life. He makes it one of the marks of "gentleness" to "have with holy bell been knolléd to church"; but it would not appear that he had often obeyed the bell's summons, though we can never suppose that he had got as low as Falstaff, and "have forgotten what the inside of a church is made of "; and almost the only passage which shows any acquaintance with Church services is the one 


\section{In My Vicarage Garden}

stanza in The Phonix and the Turtle: "Let the priest in surplus white" sing the requiem. Of the clergy, too, he has very little good to say; all degrees, whether Cardinal, Bishops, priests, or curates, were, according to him, either proud or ignorant, or both ; the only exception being Friar Francis in Much Ado About Nothing, and Friar Laurence in Romeo and Juliet, who are represented as good men and wise counsellors.

It is almost certain that Shakespeare was never out of England; and it is one of the commonplaces of Shakespearian criticism that every country in which the scenes are laid is still only the England of his own time, and all the characters, whatever foreign names they may bear, are Englishmen and English women. Still, he must have read much about foreign countries, and must have conversed with many travellers, and so must have read and heard of the beautiful buildings in foreign countries; yet he never mentions them. Two entire plays are laid in Venice, and, more suo, he speaks of "that pleasant country's earth," and he mentions the Rialto, but of the grandeur of St Mark's or the Venetian Palaces he says nothing. It is the same with all the other foreign towns he names; Milan, Vienna, Verona (occupying two entire plays), Ephesus, Sicily, Padua, Paris, Florence, etc., all celebrated for their fine buildings; but as far as we learn anything of them from Shakespeare, they might have been small English country villages of which 


\section{Shakespeare and Architecture}

little was known beyond their name. This comes out still stronger if we compare him with the two great English writers with whom he is so often compared-Bacon and Milton. To his great contemporary Bacon stately buildings and fine architecture were a great delight; according to him the study of them was a necessary part in the education of every gentleman, and he has left us the great essay On Building, an essay which not only shows his practical knowledge in joining stateliness and beauty with perfect comfort, but also shows how the greatest intellect can deal with what many would call only petty details. Milton's case is still more striking. Puritan though he was, fine and magnificent buildings appealed strongly to his poetic taste. The buildings in heaven are all after the patterns of the grandest buildings on earth, and he takes every opportunity to show his knowledge and admiration of fine architecture ; and it is a little curious in connection with Shakespeare's omission of all notice of architecture, that Milton's sonnet upon him is entirely made up of building allusions, "the labour of an age in piled stones," "a starpointing pyramid" and "marble sepulchre." And so it is in Milton and not in Shakespeare that we learn to love the beauties of "the studious cloyster pale," "the high embowed roof-

With antick pillars massy proof, And storied windows richly dight, Casting a dim, religious light"- 


\section{In My Vicarage Garden}

and it is from the Puritan Milton, and not from the no-Puritan Shakespeare that we catch the beauties of the " pealing organ blowing-

To the full-voiced Quire below,

In service high and anthems clear," etc.

Something might be said also of the fact that he makes no use of architects' or builders' technical terms. If he speaks of a "vaulted arch" it is of the sky he is speaking; and so of almost every other word which might be considered to be borrowed from the architect or builder. I say this because it is from the seemingly unconscious use of many terms peculiar to many arts and sciences that the conclusion has been drawn that he was not only a proficient in those arts and sciences, but even a member of the special professions and handicrafts; but I omit this part of the subject without going further into it.

It may, of course, be said that the entire omission of all reference to fine buildings and grand architecture proves nothing as to Shakespeare's ignorance of the art or want of observation of the buildings. It is impossible to prove a negative, and with many writers such omissions would not be worth noticing. But with Shakespeare it is different. There seems to have been almost nothing that he did not notice, and having noticed it he said something about it in his writings; and so when we find one particular subject entirely unnoticed, and that a subject which more or less 


\section{Shakespeare and Architecture}

came before him every day of his life, some explanation does seem to be required. But can we in any way explain this omission, or the other omissions? As to the dog, we may wish that he had taken a more pleasant view of him, but it is quite certain that it was not owing to want of love for animals, or want of kindness. The man who wrote much and lovingly of so many animals, beasts, birds, fishes, and insects ; the man who could say-

"The poor beetle that we tread upon

In corporal sufferance finds a pang as great

As when a giant dies"-

must have had a tender heart for all animals. It is probable that he had a physical antipathy to the dog, just as others have to a cat or to snakes :-

"Some men there are love not a gaping pig, Some that are mad if they behold a cat."

And there we may leave it. His omission of tobacco may be explained in almost the same way. Some have suggested that the omission was a compliment to the King. But Shakespeare was not a man to allow his witings to be shackled by any such overstrained courtesy, and many as loyal to the King as he was spoke freely of tobacco, and most of the plays and poems were written before James came to the throne. I should suppose that he was not a smoker, and perhaps did not like it; but he had many friends 


\section{In My Vicarage Garden}

that were smokers, and so he would not say anything about it; he would leave it alone as "ower good for banning and ower bad for blessing." But we cannot so explain away his blindness, if it was so, to all the beauties of English architecture. I am inclined to think that it must be put down to that reticence on everything connected with himself which has made it hopeless for his biographers to make out the events of his life from his writings. I can well fancy that he had such an abhorrence of anything like puffing or advertising himself that he would-it may have been purposely or it may have been unconsciously - abstain from saying many things which might bear that construction. In that way he would say nothing of the palaces or fine houses to which he may have had access, lest it should be put down to a boasting of his acquaintance with the great men of the land; and he may have abstained from details of other great buildings lest it should be put down to a desire to boast of his travels and his knowledge. That he had in him this self-restraint and self-effacement is no mere surmise; it comes out in many ways ; and it was a part of his character which many other great minds have shown. A very similar instance may be found in Bishop Butler, whose fame rests on his two great works, the Analogy and the Sermons, which will probably be among the great possessions of the English language as long as Shakespeare's works, but of whom very little 


\section{Shakespeare and Architecture}

is known beyond his writings. Dean Church, in his sermons on Pascal, etc., has a very striking passage on this self-effacement of Bishop Butler ; and has shown that, near as he is to our own day, little or nothing can be learned of him in the many places in which he passed his lifeWantage, Oxford (Oriel), London (St Paul's and the Rolls), Stanhope, Bristol, and Durham. So it seems to have been with Shakespeare; and though his silence on all points of architecture does not prove it by itself, yet, added to the other proofs, I think it strengthens them; and whatever it may prove of his habits and character, or even if it prove nothing, I think it at least noteworthy. 



\section{N D E X}

Abelia Chinensis, 3I

Abutilon Vitifolium, 44

Acaenas, 68

Aconite, winter, 4

Alpenrose, I79, 198

Alpines, high, 6I, 8I

Amaryllis, 44

Arenaria, 70

Arnica, 6I, 8I

Arundo donax, 25

Asarum, 4

Asters, 29

Astrantia, 82

Atragene, 63

Autumn colours, 34

Azara, 15

BACON, I, 28, 215

Bamboos, 25

Bear and beaver, 162

Bedding out, 38

Berkeley Castle, 2 Io

Birches, I6

Browne, Sir T., I42

Buddleia, 44

Burton, 52

Butler, Bp., 218

Buttercups, II I

Butterfly, I64

California Bay, I30

Campanula barbata, 82

- Medium, I37

- Portenshlageana, 68

Capparis, 44

Chester, rock garden at, 84

Cheimonanthus, 7, Io, 48

Chilian shrubs, 64

Chrysanthemum Tchihatchewii, 68
Clematis, 33 cirrliosa, 7

Colchicum, I82

Cole, 52

Compositae, I26

Cornus Mas, 49

Cotoneaster, 35

Crinum Capense, 44

Crocus, 6 Autumnal, 3I

Cruciferae, I24

Curtis, Bot. Mag., 74

Cyclamen, 3, 50

Cypripedium, 63

DAFFODILS, I2

Daphne, 49

de Paas, Crispin, 5, 78

Destruction of plants, I 70

Earle, Professor, 99, 105

Echium vulgare, I39

Edelweiss, I84

Edinburgh, rock garden at, 85

Elm, 166

Elwanger, 90

Entomological names, 100

Epinal Glossary, I05

Erica, 50

Evelyn, 6

FoRsythia, 15, 47

Fremontia, 43

Fuchsia, 44

GARRYA elliptica, 49

Gentians, I80, I97

Geraniums, IOI

Gerard, 75

Gilbert's Florist, 92 


\section{Index}

Gotthard Pass, 189

Gramineae, I 26

Helleborus niger, 52

Hepatica, 53

Herniaria, 70

Hippophæ, 33

Homer, I07

Horse chestnut, I66

Hutchinsia, 70

IRIS Stylosa, I I

Kew, 145

rock garden at, 87

Kohlreuteria, I7

LABIATAE, I 24

Laurembergius, 5

Laurestinus, 8

Lilium auratum, 64

Linnæus on scents, I I 4

Lithospermum, I8 5

Lonicera, 8, 48

Lucretius, I IO, I I 3, I 30

MAw, monograph of crocus, 6

Medical plant-names, IO3

Miller, Gardener's Dictionary, 74

Milton, 9, I16, 2 I 5

Opuntia, 44

Oxalis, wild, I 7

Paeony, 76

Paliurus, 22

Paradisia liliastrum, 199

Parkinson, 76, 96

Parottia, 49

Persimmon, 32

Photinia, I 5, 48

Phygelius, 32

Physianthus, 44

Plagianthus, 43

Plantain, 26

Plymouth, rock garden at, 87

Portuguese gardens, 88
Primula farinosa, 198

Pulmonaria, 54

RANUNCULACEAE, I23

Rhododendron, 48

Rhus cotinus, 23

Rosa hemispherica, 20, 79

- Mundi, 92

- Versicolor, 91

Rosaceae, 125

Rudbeck, 73

SAgina, 67

Salisburia, 35

Saxifraga aizoides, I79

Scotch Fir, I67

Sempervivum arachnoideum, I80, 199

Sibthorp, Flora Græca, 73

Signatures, 122

Sisymbrium irio, I 36

Solanum anthropophagum, I44

Southsea, rock garden at, 83

Spenser, 65

Sycamore, 160

TenCrium latifolium, 44

Tulips, 13

Ulex nanus, 8, 34

Upas, I3I

Urus, 162

VALERIAN, 137

Van Oosten, I4

Vere, Aubrey de, 5 I

Veronica, 70

WALL garden, 88

Water Lily, I 7 I

Weeds, 26

Windsor Castle, 2 I0

Wistaria, 22

Wolf, 163

Worthing, rock garden at, 83

Wotton, Sir H., $4 \mathrm{I}$

YUCCA, 44, II 2 


\section{Handbooks of Practical}

\section{Gardening}

Under the General Editorship of HARRY ROBERTS

Crown 8vo. Illustrated. Cloth.

Price 2s. 6d. net per volume. Price $\$ 1.00$ net.

Vol. I.-THE BOOK OF ASPARAGUS. With sections also on Celery, Salsify, Scorzonera, and Seakale; together with a chapter on their cooking and preparation for the table. By CHARLES ILOTT, F.R.H.S., Lecturer on Horticulture to the Cornwall County Council.

The Pilot-" Every point is carefully dealt with, and the book should prove extremely useful to scientific gardeners."

The Daily Mail- "The admirable chapter contributed by Dr Harry Roberts on the Cookery of Asparagus."

The Speaker - "The work of a specialist. Mr Ilott gives us-for a matter of half-a-crown-the ripe experience of a life-time well illustrated."

The Gardeners' Chronicle- "The author is eminently qualified for the task he has undertaken. .... In a careful, thorough manner the cultivator is instructed in every operation involved in the cultivation of the plant."

Gardening Illustrated-"The author has handled his subject in a thoroughly practical manner, and is to be congratulated on having compressed so much valuable matter into so small a compass."

The Scotsman-"Most serviceable. ... The letterpress is beautifully and usefully illustrated, while the get-up of the book generally is very tasteful."

The World - "This very useful series should by no means be missed from the library of the sincere gardener."

The Daily Chronicle-"The Book."

The Morning Post-" Particularly sound advice. .. . The information throughout is treated in a simple and intelligible manner."

The Garden - "Very plain and practical. Many useful illustrations from photographs and sketches are dispersed throughout the book. The best kinds of Asparagus for decorative purposes are described by Dr Roberts, who gives also many interesting details concerning the history and cookery of these vegetables. Altogether a very readable book."

Spectator-"We specially commend this little volume to our readers."

JOHN LANE : LONDON: VIGO STREET, W. 


\section{Vol. II.-THE BOOK OF THE GREENHOUSE.} By J. C. TALLACK, F.R.H.S., Head Gardener at Shipley Hall.

The Outlook - "A serviceable handbook for the practical gardener, written with exceptional knowledge of horticultural work. A special chapter deals with the little town greenhouse."

The Glasgow Herald-" The essence of a practical gardener's large experience of greenhouse work. The illustrations are new and good."

The Bristol Mercury-" Will be invaluable to amateurs."

The Scotsman-"Of service not only to amateurs but to professional horticulturists. . . A number of beautifully produced illustrations."

The Liverpool Mercury - "Each chapter is marked with simple treatment, the outcome of practice."

The Westminster Goacette-"An eminently practical and useful book."

The Western Morning News-"Excellent garden handbooks. . . The beautiful frontispieces to the various volumes in the series."

The Pall Mall Gazette-" The least technical and one of the best informed books on the growing of plants under glass that we have ever seen."

Vol. III.-THE BOOK OF THE GRAPE. Together with a chapter on the History and Decorative Value of the Vines. By H. W. WARD, F.R.H.S., for twenty-five years Head Gardener at Longford Castle.

The St James's Gazette- "A mine of useful information."

The Outlook- "A sensible, practical treatise by an expert."

The Pall Mall Gazette-" The smallest vine grower will find this book an excellent counsellor and guide, whilst it will be found comprehensive enough for the most exacting specialist."

The World-" "The excellent series."

The Queen-" An interesting and exhaustive treatise."

Vol. IV.-THE BOOK OF OLD-FASHIONED FLOWERS. By HARRY ROBERTS, author of "The Chronicle of a Cornish Garden."

Vol. V. - THE BOOK OF BULBS. By S. ARNOTT, of Carsethorne, near Dumfries.

Vol. VI.-THE BOOK OF THE APPLE. By H. H. THOMAS, Assistant Editor of "The Garden," late of the Royal Gardens, Windsor. Together with chapters by the Editor on the History and Cooking of the Apple and the Preparation of Cider.

Vol. VII.-THE BOOK OF VEGETABLES. Вy GEORGE WYTHES, V.M.H., Head Gardener at Syon House. Together with chapters on History and Cookery, by the Editor.

Vol. VIII. - THE BOOK OF THE DAFFODIL. By the Rev. G. H. ENGLEHEART. 


\section{BOOKS ABOUT GARDENS}

Seven Gardens and a Palace. By "E. V. B.," Author of "Days and Hours in a Garden." Illustrated by F. L. B. GrigGs and ARTHur Gordon. Price 5s. net. Crown 8 vo. Price $\$$ I. 5 o. Third Edition.

The Chronicle of a Cornish Garden. By Harry Roberts. With Seven ideal Illustrations by F. L. B. Griggs. Price 5s. net. Crown 8vo. Price \$r.5o.

Of Gardens: An Essay. By Francis BACON. With an Introduction by HELEN Milman and a Cover-design and Frontispiece by Edmund N. New. Demy r6mo. Price 2s. 6 d. net.

A Garden in the Suburbs. By Mrs LesLie Williams. With Eight Illustrations. Price 5s. net. Crown 8vo. Price \$1.50.

Stray Leaves from a Border Garden. By Mrs Milne-Home. With Eight Illustrations by F. L. B. Griggs. Price 6s. net. Crown 8 vo. Price $\$ 2.00$.

My Vicarage Garden. By Canon EllaсомвE, Author of "In a Gloucestershire Garden," \&c. With Illustrations by F. L. B. Griggs. Price 5s. net. Crown 8vo. Price \$r.5०.

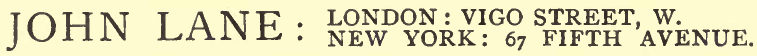




\section{BOOKS ABOUT GARDENS}

In the Garden of Peace. By Helen Milman (Mrs Caldwell Crofton). With 24 Illustrations and Cover-design by EDMUnd H. NEw. Price 5s. net. Crown 8vo. Price \$r.5o. Third Edition.

Outside the Garden. By Helen Milman (Mrs Caldwell Crofton). With 24 Illustrations and Coverdesign by Edmund H. New. Price 5s. net. Crown 8vo. Price \$1.50.

My Roses and How I Grew Them. By Helen Milman (Mrs Caldwell Crofton). With a Cover-design by EDMUnd H. NEw. Price is. 6d. net. Crown 8vo. Price 75 cents. Third Edition.

Flowers and Gardens. By Forbes Watson. With Photogravure Portrait of the Author. Edited, with a Biographical Note by Canon ELLACOMBE. Price 5s. net. Crown 8vo. Price \$I.50. Nerw Edition.

Garden-Craft Old and New. Ву Јонм D. SEDDING. With a Memorial Notice by the Rev. E. F. RUSSELL, and nine full-page Illustrations. Price 7s. 6d. net. Demy 8vo. Price $\$ 2.50$.

Nere Edition.

The Birds of My Parish. By E. H. Pollard. With Collotype Illustrations. Price 5s. net. Crown 8vo. Price \$I.50.

From the Heart of the Rose: Letters on Things Natural, Things Serious, Things Frivolous. By Helen Milman (Mrs Caldwell Crofton). With a Photogravure Frontispiece and a Cover-Design by E. H. NEw. Price 5s. net. Crown 8vo. Price \$I.50 net. 


\section{BOOKS FOR COUNTRY HOUSES}

The Natural History of Selborne. By GILBERT WHITE. Edited, with Introduction, by GRANT ALLEN. With upwards of 200 Illustrations by Edmund H. New. Price 5s. net. Crown 8vo. Price \$1.50.

"The attraction lies chiefly in finding the masterpiece so admirably illustrated by $\mathrm{Mr}$ Edmund $\mathrm{H}$. New. In black and white line work of this class he has no equal." (Country Life.)

"Mr Edmund New's drawings are not merely artistic, but full of the poetry of association." (Speaker.)

\section{The Compleat Angler. By IzaAk Walton} and Charles CotTon. Edited, with an Introduction, by Richard Le GallienNe. With Photogravure Portraits of Walton and Cotton, and over 250 Illustrations and Cover-design by EDMUND H. New. Price I 5s. net. Fcap. 4to. Price $\$ 6.00$ net.

"A delightful edition, charmingly illustrated." (Punch.)

"Of Mr Edmund H. New's illustrations we cannot speak too highly. We have never seen better." (Spectator.)

"One of the best editions; one, we cannot help thinking, that Walton himself would have preferred." (Daily Chronicle.)

\section{All About Dogs. A Book for Doggy People.} By Charles Henry Lane. With 85 Full-page Illustrations (including nearly 70 champions) by R. H. MOORE. Demy 8vo. Price 7s. 6d. net. Gilt top. Price \$2.50 net.

\footnotetext{
"One of the most interesting contributions to the literature of the day." (Daily Chronicle.)

"Mr Lane's book is worthy of a place on the shelves of any sporting library." (Outlook.)

"A most interesting, indeed, an entirely fascinating book." (St James's Gazette.)
} 


\section{Flowers of Parnassus}

A Series of Famous Poems Illustrated

Under the General Editorship of

F. B. MONEY-COUTTS

Demy $16 \mathrm{mo}\left(5 \frac{3}{4} \times 4 \frac{1}{2}\right.$ inches). Gilt top

Price Is. net. Bound in Cloth. Price 50 cents net. Price Is. 6d. net. Bound in Leather. Price 75 cents net.

Vol. I.-GRAY'S ELEGY AND ODE ON A DISTANT PROSPECT OF ETON COLLEGE. With Twelve Illustrations by J. T. FRIEDENSON.

Vol. II.-THE STATUE AND THE BUST. By RoberT Browning. With Nine Illustrations by PHILIP CONNARD.

Vol III.-MARPESSA. By Stephen Phillips. With Seven Illustrations by PHILIP ConNaRD.

Vol. IV.-THE BLESSED DAMOZEL. By DANTE Gabriel Rossetti. With Eight Illustrations by PERCy BULCOCK.

Vol. V.-THE NUT-BROWN MAID. A New Version by F. B. Money-CoutTs. With Nine Illustrations by Herbert Cole.

Vol. VI.-A DREAM OF FAIR WOMEN. By AlFRed Tennyson. With Nine Illustrations by Percy Bulcock.

Vol. VII. - THE DAY DREAM. By Alfred TENNyson. With Eight Illustrations by AMELIA BAUERLE.

Vol. VIII.-A BALLADE UPON A WEDDING. By Sir JoHN SUCKLING. With Nine Illustrations by HerberT COLE.

Vol. IX.-RUBÁIYÁT OF OMAR KHAYYÁM: Rendered into English Verse by EDward FitzGerald. With Nine Illustrations by HERBERT COLE.

Vol. X.- THE RAPE OF THE LOCK. By ALEXANDER POPE. With Nine Illustrations by AUBREY BEARDSLEY.

Vol. XI.-CHRISTMAS AT THE MERMAID. By Theodore WatTs-Dunton. With Nine Illustrations by HERBERT COLE.

Vol. XII.-SONGS OF INNOCENCE. By William Blake. With Eight Illustrations by Geraldine MORRIS. Other Volumes in Preparation

JOHN LANE : LONDON: VIGO STREET, w. JOHN LANE : NEW YORK: 67 FIFTH AVENUE. 



\section{UNIVERSITY OF CALIFORNIA LIBRARY BERKELEY}

Return to desk from which borrowed. This book is DUE on the last date stamped below.

\section{Mar'53 HH}

MAR

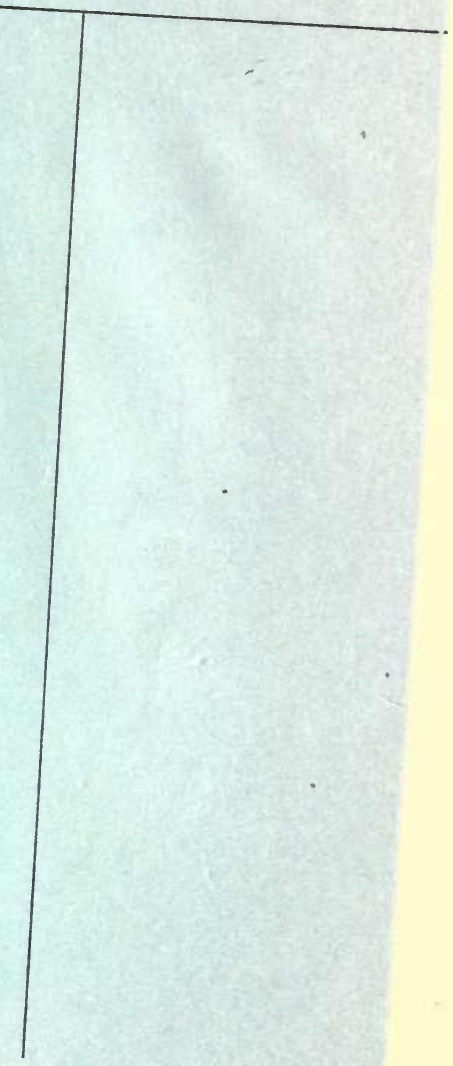


<smiles>C=CC(C)C</smiles> 
